\title{
Calcium/magnesium ratio and water potential effects on forage quality and pectin concentration
}

\author{
Rishi Prasad \\ West Virginia University
}

Follow this and additional works at: https://researchrepository.wvu.edu/etd

\section{Recommended Citation}

Prasad, Rishi, "Calcium/magnesium ratio and water potential effects on forage quality and pectin concentration" (2010). Graduate Theses, Dissertations, and Problem Reports. 3015.

https://researchrepository.wvu.edu/etd/3015

This Thesis is protected by copyright and/or related rights. It has been brought to you by the The Research Repository @ WVU with permission from the rights-holder(s). You are free to use this Thesis in any way that is permitted by the copyright and related rights legislation that applies to your use. For other uses you must obtain permission from the rights-holder(s) directly, unless additional rights are indicated by a Creative Commons license in the record and/ or on the work itself. This Thesis has been accepted for inclusion in WVU Graduate Theses, Dissertations, and Problem Reports collection by an authorized administrator of The Research Repository @ WVU. For more information, please contact researchrepository@mail.wvu.edu. 


\title{
Calcium/Magnesium Ratio and Water Potential Effects on Forage Quality and Pectin Concentration.
}

\section{RISHI PRASAD}

\author{
Thesis submitted to the \\ Davis College of Agriculture, Natural Resources and Design \\ at West Virginia University \\ in partial fulfillment of requirements for the degree of \\ Master of Science \\ in \\ Plant and Soil Sciences
}

Louis M. McDonald, Ph.D., Chair

Edward B. Rayburn, Ph.D.

William B. Bryan, Ph.D.

Division of Plant and Soil Sciences

Morgantown, West Virginia

2010

Keywords: Soil Acidity; Calcium/Magnesium Ratio; Water Potential; Forage Quality; Pectin. 


\section{ABSTRACT \\ Calcium/Magnesium Ratio and Water Potential Effects on Forage Quality and Pectin Concentration.}

\section{Rishi Prasad}

Forage quality is an important parameter in animal nutrition and depends partly on soil fertility and moisture. Acidic soil pH and low soil moisture are known to decrease forage yield and quality. Liming is a common practice to correct the soil $\mathrm{pH}$. Addition of lime not only improves the availability of nutrients but at the same time adds to the native calcium and magnesium present in the soil. Calcium and magnesium are identified as essential secondary macronutrients known to influence plant's physiological process. The objective of this experiment was to determine the effect of molar combinations of $\mathrm{Ca}: \mathrm{Mg}$ ratio in liming agent and water potential (WP) on yield, crude protein concentration, mineral concentration, pectin concentration and concentrations of fiber components (neutral detergent fiber, acid detergent fiber, and acid detergent lignin) in sudangrass and red clover. The experiment was conducted in a greenhouse as a completely randomized design with nine calcium/magnesium ratios maintained at two WP levels with five replications. Both $\mathrm{Ca} / \mathrm{Mg}$ ratio and WP significantly affected the above mentioned forage quality parameters. A Soil $\mathrm{Ca} / \mathrm{Mg}$ ratio of $11: 1$, obtained by the application of $80-20(\%) \mathrm{Ca}(\mathrm{OH})_{2}-\mathrm{Mg}(\mathrm{OH})_{2}$, was found to be optimal. Frequently irrigated condition (WP $16 \mathrm{kPa}$ ) increased forage accumulation, decreased crude protein concentration, increased mineral uptake, and increased fiber components. Pectin concentration was also increased by $\mathrm{Ca} / \mathrm{Mg}$ ratioa significant finding of our study. 


\section{ACKNOWLEDGEMENTS}

In Loving memory of my Grand ma Smti. Rajeshwari Devi and Grand Pa Dr. Ramlawlin Prasad.

My sincere thanks to all the persons who were directly or indirectly involved in this research project. My special thanks goes to Dr. Louis M. McDonald for his support, intellect, and giving me the opportunity to study in United States and conduct this research under his deft guidance.

I would also like to thank my committee members: Dr Ed Rayburn for his critical suggestions and having faith on my abilities; Dr Bryan for being a true agronomist, a nice person and answering my doubts whenever I needed him and Dr. Eugene E. D. Felton for his lab and suggestions.

I am also thankful to lab technicians: Elizabeth Joan Wright, Tammy Webster and Stephanie Pauley for technical support on my experiments. Research experience shared by Domingo Mata Padrino and his time to time suggestions helped me gearing up my pace. I would also like to thank student workers: Suzy, Sumanth, and Emily for helping me with my lab work. I am also thankful to my lab group members and fellow graduate students Lynn, Sri, Mimi and Jared, for sharing, supporting and providing me motivation which is highly required in graduate studies.

Above all, I am grateful to my parents Mr. Raj Lalit Prasad, and Ms. Meena Prasad behind all my inspirations. I am also thankful to my brother Ravi, Rajive and Vikrant for their love and keeping me out of the family responsibility during my study period in United States. Last but not the least, my alma mater G.P.U.A. \&T, Pantnagar, for providing me the best friends and the best years of my life. 


\section{TABLE OF CONTENTS}

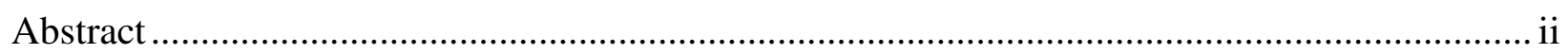

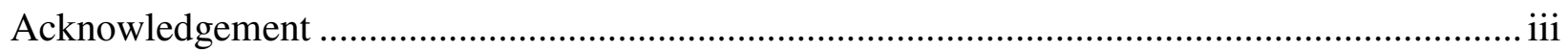

Table of contents ........................................................................................................ iv

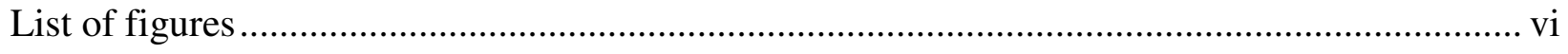

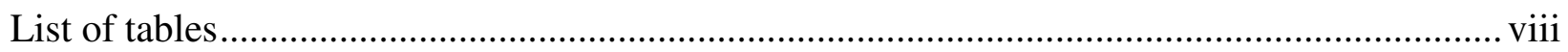

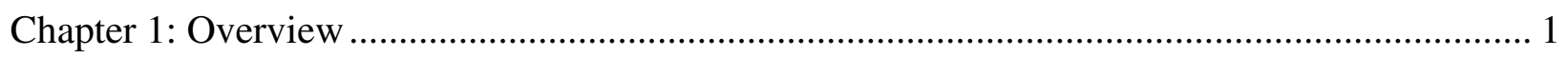

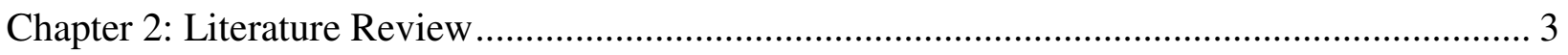

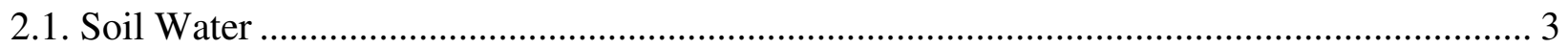

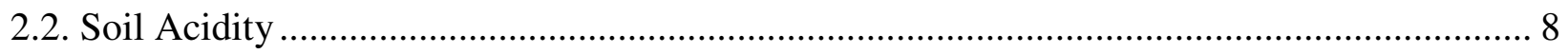

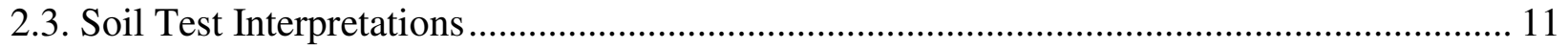

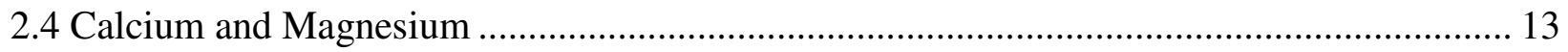

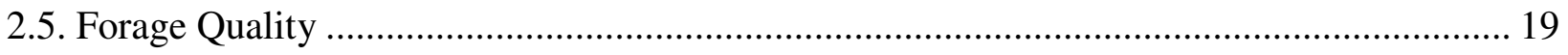

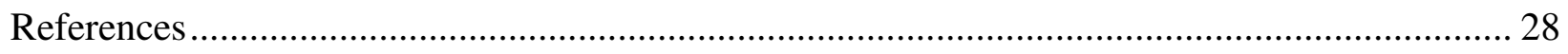

Chapter 3: Effect of Water Potential and Liming Agent Calcium/Magnesium Ratio of on Sudangrass and Red clover Forage Yield and Quality .............................................................. 44

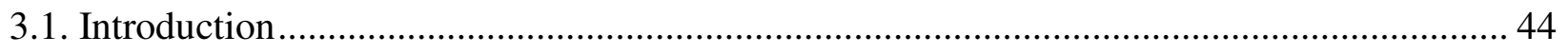

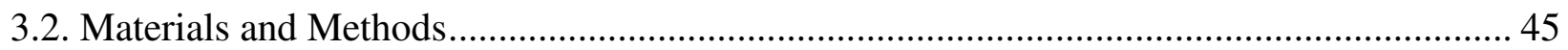

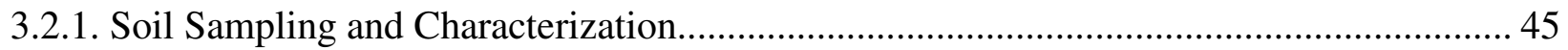

3.2.2. Lime Requirement and Incubation Experiment ................................................................... 46

3.2.3. Water Potential Treatments and the Experimental Setup …………………….................. 48

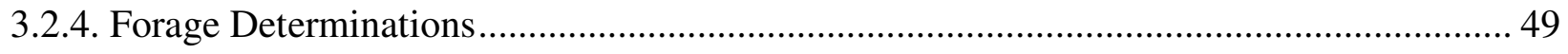

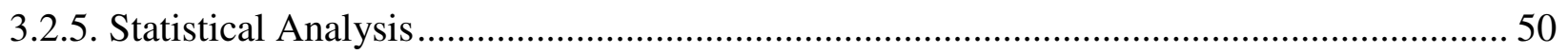

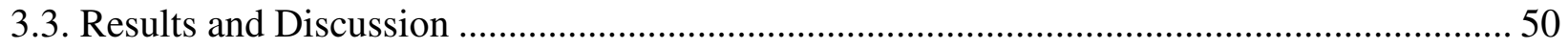




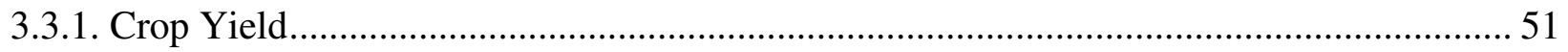

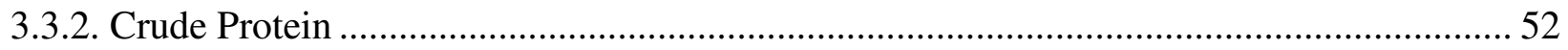

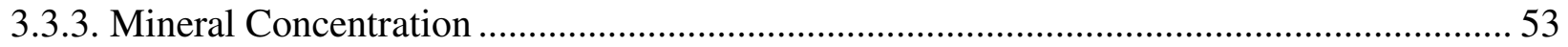

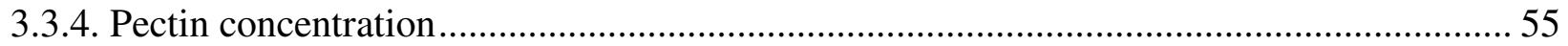

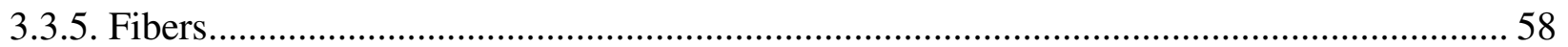

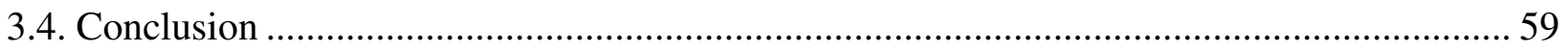

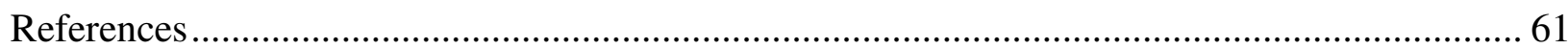

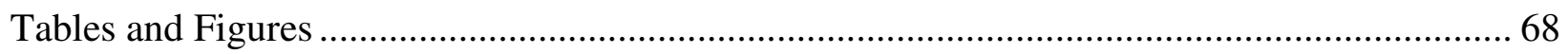

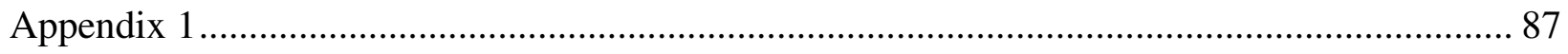

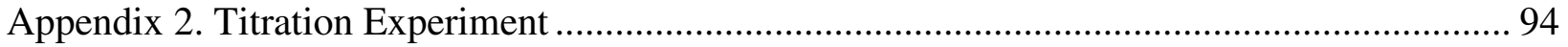

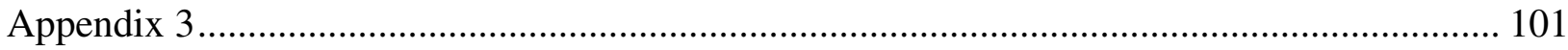

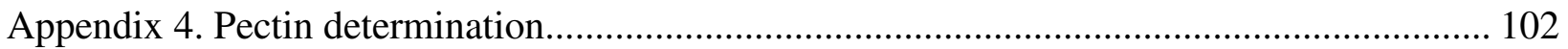

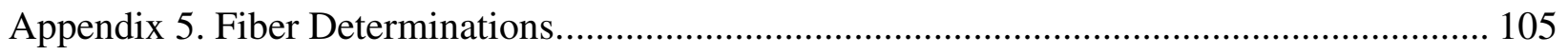

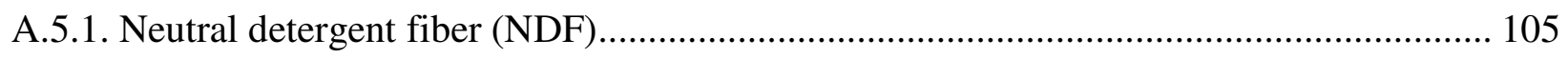

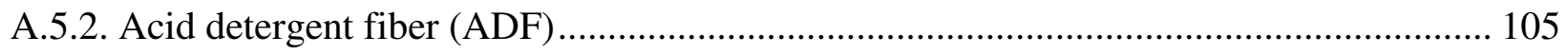

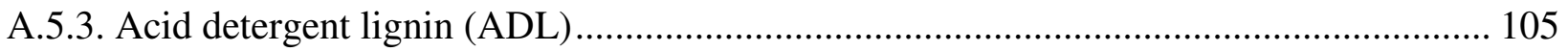




\section{LIST OF FIGURES}

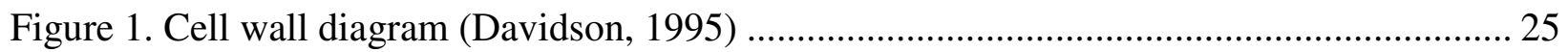

Figure 2. Schematic representation of Pectin (Hangarter, 2004)............................................. 26

Figure 3. Schematic representation of calcium binding to polygalactoronate sequences: 'egg box' dimer and 'egg-box'cavity (Axelos \& Thibault, 1991)................................................................. 27

Figure 3.1. Crude protein (\%) of red clover across nine $\mathrm{Ca}: \mathrm{Mg}$ ratio and two water potential treatments. $\mathrm{CP}(\mathrm{H})$ represents crude protein $(\%)$ in frequently irrigated condition and $\mathrm{CP}(\mathrm{L})$ represents crude protein (\%) in poorly irrigated condition. Solid line represents fitted trend line (polynomial) through all ratios. Fischer's least significant difference for each water potential at given $\mathrm{Ca} / \mathrm{Mg}$ ratios are: 0.97 (4:1), 0.88 (6:1), 1.92 (7:1), 1.67 (8:1), 1.43 (10:1), 1.13 (11:1), 3.07 (12:1), $1.13(14: 1), 1.52(17: 1)$.

Figure 3.2. Tissue $\mathrm{Ca}$ and $\mathrm{Mg}(\%)$ in young leaf blade of sudangrass across nine $\mathrm{Ca} / \mathrm{Mg}$ ratio and two water potential. $\mathrm{H}$ represents frequently irrigated condition and $\mathrm{L}$ poorly irrigated condition. Solid line represents fitted trend line (polynomial) through all ratios. 82

Figure 3.3. Tissue $\mathrm{Ca}$ and $\mathrm{Mg}(\%)$ in red clover across nine $\mathrm{Ca} / \mathrm{Mg}$ ratio and two water potential. $\mathrm{H}$ represents frequently irrigated condition and $\mathrm{L}$ represents poorly irrigated condition. Solid line represents fitted trend line (polynomial) through all ratios. 83

Figure 3.4. Interaction effects of $\mathrm{Ca} / \mathrm{Mg}$ ratio and water potential on pectin concentration in young leaf blade (sudangrass). Pectin $(\mathrm{H})$ represents pectin $(\%)$ in frequently irrigated condition and Pectin (L) represents pectin (\%) in poorly irrigated condition. Solid line represents fitted trend line (polynomial) through all ratios. Fischer's least significant difference (LSD) for each water potential at given $\mathrm{Ca} / \mathrm{Mg}$ ratios are: 0.21 (4:1), 0.28 (6:1), 0.21 (7:1), 0.18 (8:1), 0.28 (10:1), 0.37 (11:1), $0.45(12: 1), 0.37$ (14:1), and $0.49(17: 1)$.

Figure 3.5. Interaction effects of $\mathrm{Ca} / \mathrm{Mg}$ ratio and water potential on pectin concentration in old leaf blade (sudangrass). Pectin $(\mathrm{H})$ represents pectin $(\%)$ in frequently irrigated condition and Pectin (L) represents pectin (\%) in poorly irrigated condition. Solid line represents fitted trend line (polynomial) through all ratios. Fischer's least significant difference (LSD) for each water potential at given $\mathrm{Ca} / \mathrm{Mg}$ ratios are: 0.21 (4:1), 0.64 (6:1), 0.58 (7:1), 1.64 (8:1), 0.86 (10:1), 0.69

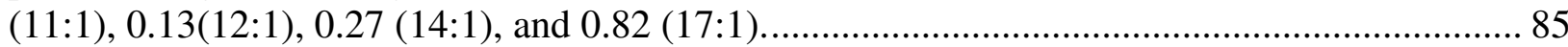

Figure 3.6. Interaction effects of $\mathrm{Ca} / \mathrm{Mg}$ ratio and water potential on pectin concentration in red clover. Solid line represents fitted trend line (polynomial) through all ratios. Pectin $(\mathrm{H})$ represents pectin (\%) in frequently irrigated condition and Pectin (L) represents pectin (\%) in poorly irrigated condition. Fischer's least significant difference (LSD) for each water potential at 
given $\mathrm{Ca} / \mathrm{Mg}$ ratios are: 0.28 (4:1), 0.34 (6:1), 1.41 (7:1), 0.34 (8:1), 1.00 (10:1), 1.47 (11:1), $0.83(12: 1), 0.70(14: 1)$, and $0.99(17: 1)$.

Figure A.2.1. Soil titration with $0.022 \mathrm{M} \mathrm{Ca}(\mathrm{OH})_{2}$ used for prediction of lime requirement...... 96

Figure A.4.1. Stability of Galacturonic acid (GalA) standards with time. 103

Figure A.4.2. Standard curve for Galacturonic Acid (GalA). 104 


\section{LIST OF TABLES}

Table 3.1. Soil physical and chemical properties prior to liming treatment application. 68

Table 3.2. Soil test (Mehlich1) Ca and Mg concentrations (mg/kg soil), their sufficiency range and the resulting $\mathrm{Ca}$ : $\mathrm{Mg}$ ratios in the soil.

Table 3.3. ANOVA output for herbage accumulation of sudangrass and red clover. 70

Table 3.4. ANOVA outout for crude protein percentage in sudangrass young leaf blade, sudangrass old leaf blade and red clover.

Table 3.5. Model observed significance levels of $\mathrm{Ca}, \mathrm{Mg}, \mathrm{P}$, and $\mathrm{K}$ for sudangrass young leaf blade, sudangrass old leaf blade, and red clover.

Table 3.6a. Mean herbage accumulation (whole plant), crude protein, $\mathrm{Ca}, \mathrm{Mg}, \mathrm{P}$ and $\mathrm{K}$ concentration in sudangrass young leaf blade and sudangrass old leaf blade at each water potential

Table 3.6b. Mean herbage accumulation (whole plant), crude protein, $\mathrm{Ca}, \mathrm{Mg}, \mathrm{P}$ and $\mathrm{K}$ concentration in sudangrass young leaf blade and sudangrass old leaf blade at each $\mathrm{Ca} / \mathrm{Mg}$ ratio.

Table 3.7. Main effects of $\mathrm{Ca} / \mathrm{Mg}$ ratio and water potential on dry matter, crude protein concentration and tissue mineral concentrations in red clover.

Table 3.8. Mean and standard error (SE) for Water Potential (High or Low) and Ca/Mg Ratio for red clover dry matter yield. 76

Table 3.9. ANOVA output for pectin concentration in sudangrass young leaf blade, sudangrass old leaf blade, and red clover.

Table 3.10. ANOVA output for fiber components concentration in sudangrass young leaf blade, sudangrass old leaf blade, and red clover. .78

Table 3.11a. Main effects of water potential on fiber components in sudangrass and red clover.79

Table 3.11b. Main effects of $\mathrm{Ca} / \mathrm{Mg}$ ratio on fiber components in sudangrass and red clover.... 80

Table A.1.1. Average daily temperature and water potential averaged over week for the entire growing period. WP $(\mathrm{H})$ represents water potential in frequently irrigated condition and WP (L)

represents water potential in poorly irrigated condition. 87 
Table A.1.2. Interaction means for herbage accumulation of sudangrass. WP $(\mathrm{H})$ represents water potential in frequently irrigated condition and WP (L) represents water potential in poorly irrigated condition. SD and SE are standard deviation and standard error of means at each treatment levels.

Table A.1.3. Interaction means for crude protein percentage in young leaf blade of sudangrass. WP $(\mathrm{H})$ represents water potential in frequently irrigated condition and WP $(\mathrm{L})$ represents water potential in poorly irrigated condition. SD and SE are standard deviation and standard error of means at each treatment levels.

Table A.1.4. Interaction means for crude protein percentage in old leaf blade of sudangrass. WP (H) represents water potential in frequently irrigated condition and WP (L) represents water potential in poorly irrigated condition. SD and SE are standard deviation and standard error of means at each treatment levels.

Table A.1.5. Interaction means for tissue mineral concentration in young leaf blade of sudangrass. WP $(\mathrm{H})$ represents water potential in frequently irrigated condition and WP (L) represents water potential in poorly irrigated condition. SD is standard deviation of means at each treatment levels.

Table A.1.6. Interaction means for tissue mineral concentration in old leaf blade of sudangrass. WP $(\mathrm{H})$ represents water potential in frequently irrigated condition and WP (L) represents water potential in poorly irrigated condition. SD is standard deviation of mean at each treatment levels.

Table A.1.7. Interaction means for tissue mineral concentration of red clover. WP $(\mathrm{H})$ represents water potential in frequently irrigated condition and WP (L) represents water potential in poorly irrigated condition. SD is standard deviation of mean at each treatment levels.

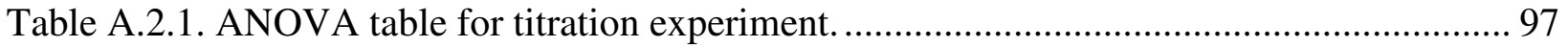

Table A.2.2. Summary statistics for titration experiment................................................. 98

Table A.2.3. Amount of liming agents applied to each treatment combinations....................... 99

Table A.2.4. Soil $\mathrm{pH}$ after mixing with respective treatment combination. Values equal \pm one standard deviation.

Table A.3.1. Interaction means for pectin concentration in sudangrass and red clover. WP $(\mathrm{H})$ represents water potential in frequently irrigated condition and WP (L) represents water potential in poorly irrigated condition. SE is standard error of means at each treatment levels. 101

Table A.4.1 Detection limits for Galacturonic acid. 104 


\section{CHAPTER 1: Overview}

In West Virginia, much of the land is on hillsides. Forage based agricultural systems allow economic use of such steep terrains. The undulating topography and uneven rainfall distribution both seasonally and spatially, create conditions where water potential varies within a farm or field. Low water availability combined with poor nutrient supply limits plant development and reduces forage yield and quality. Soil acidity is another limiting factor in West Virginia soils that reduces the availability of macro and micronutrients. This also creates conditions for reduced productivity and poor quality crops. Liming is the most common practice to correct the soil acidity problem. Liming improves soil $\mathrm{pH}$ and enhances the availability of alkali and alkaline earth cations. Continuous use of calcitic liming agents can induce magnesium deficiency due to the tendency of calcium ions to compete with magnesium ions. Animals grazed on such lands are susceptible to the Mg deficiency disease Grass Tetany or Grass Staggers. Use of dolomitic liming agents reduces the occurrence of Grass Tetany but in a low input/low return beef and sheep production systems, producers are hesitant to amend soils with the more expensive dolomitic materials.

Much is known about the benefits of limestone additions in soil, but effects of added $\mathrm{Ca}$ or Mg on plant's ability to synthesize biomolecules such as pectin, nonstructural carbohydrates, proteins, nucleic acids, lipids, amino acids, etc and thus forage quality is less well known. Calcium and $\mathrm{Mg}$ are essential macronutrients and play an important role in soil-plant relationships. Besides playing a key role in cell wall deposition, $\mathrm{Ca}$ is involved in signal transduction pathways and is a cofactor for several enzymes. Magnesium plays a vital role in 
photosynthesis, since it is the central metal atom in the porphyrin ring of the chlorophyll molecule. Magnesium also acts as an activator of many enzymes. The current research focuses on understanding the effects of added $\mathrm{Ca}$ and $\mathrm{Mg}$ in liming agents and water potential on forage quality parameters. The forage quality parameters selected for the purpose of this research include pectin concentration, crude protein, neutral detergent fiber (NDF), acid detergent fiber (ADF), acid detergent lignin (ADL) and mineral concentration of two forage species sudangrass (Sorghum bicolor) and red clover (Trifolium pratense). Since water potential differences along the slope and soil acidity are the primary limiting factors in WV pasture soils, this research will broaden our understanding of plant responses to $\mathrm{Ca}$ : $\mathrm{Mg}$ ratio (applied through liming agents) and their interactions with water levels for production of higher quality forage. 


\section{CHAPTER 2}

\section{Literature Review}

\subsection{Soil Water}

In West Virginia, of the 1.4 million hectare of farm land, 0.21 million hectares is in pasture (National Agricultural Statistics Service, 2005), and pasture-raised beef and sheep production is the major agricultural activity in the mountainous terrain of WV. Much of the soil in WV is acidic (Ritchey and Snuffer, 2002), low in native fertility and found on steep slopes. Basic cations are removed at a faster rate than their liberation from non-exchangeable forms (DeWalle et al., 1985) and this result in soils dominated by variable charge minerals (Ritchey and Snuffer, 2002). Further, the undulating topography and uneven rainfall distribution imparts variability over the toposequence (Baligar et al., 1985) where water potential varies within the farm or field. Thus forage based agricultural systems allow economic use of the often steep terrain; however the economic return from forage is relatively low. Low soil $\mathrm{pH}$ and water availability limit the overall productivity and quality of forages. Therefore it is important that soil amendments and fertilizers be applied in a way that maximizes the return on investment, maintains the productivity of the grassland system, and produces high quality forage.

Landscape position in the Appalachian region strongly affects soil water relations and crop yield (Bronson et al., 2001; Boyer et al., 1990). Lower landscape positions are more productive compared to side slopes owing to better water availability (Bronson et al., 2001). There is an inverse relationship between volumetric water content and the slope gradient (Li et al., 2001). The soil-water supply changes progressively along the slope and induces drought 
stress in the plants growing at the higher elevations. Thus, water availability significantly influences soil nutrient status and crop productivity (Fiez et al., 1994; Pennock et al., 1987).

Soil moisture and nutrient availability are closely linked and govern many of the physical, chemical and microbiological processes in the soil system. Soil water drives nutrient delivery and uptake by root interception, diffusion and mass flow. Plants growing in moist soil intercept more $\mathrm{Ca}^{2+}$ and $\mathrm{Mg}^{2+}$ than drier soils (Tisdale, 1993). Rates of nutrient diffusion also depend on soil water content. Thicker water films result in faster effective diffusion rates (Tisdale, 1993). Thus soil moisture levels directly affects nutrient absorption and indirectly plant metabolic activity and physiology (Tisdale, 1993).

In an experiment to study the effect of wet and dry cycles on mineral nutrient uptake of two grasses (Agrostis stolonifera L. and Festuca ovina L), Misra and Tyler (2000) found a significant difference in shoot uptake and concentration of $\mathrm{Cu}, \mathrm{K}, \mathrm{Mn}, \mathrm{P}, \mathrm{S}, \mathrm{Zn}, \mathrm{Fe}$ and $\mathrm{Mg}$ between wet/dry treatment (35-100\% water holding capacity, WHC) and constant water regime (60\% WHC). Nutrient uptake was lower in wet/dry treatment than in the constant water regime. Post harvest soil analysis indicated a significant difference in soil $\mathrm{pH}, \mathrm{Mg}, \mathrm{K}, \mathrm{NH}_{4}$, and $\mathrm{NO}_{3}$ concentrations. Soil $\mathrm{pH}$ was higher in the constant treatment than in the wet/dry treatment. They also found a lower total biomass production in wet/dry condition than in the constant water regime.

Despite the presence of adequate nutrients in the soil, crop yield decreases in drought periods. Saeed and Nadi (1998) studied the response of forage sorghum (Sorghum bicolor L.) to three irrigation treatments: light frequent, moderate less frequent and heavy infrequent. They observed that drymatter production (16.3 tonnes $\left.\mathrm{ha}^{-1}\right)$ was highest for the frequent irrigation 
treatment. Nielsen (2004) also observed a similar trend in drymatter production to increased water availability. Drymatter yield of Kenaf (Hibiscus cannabinus L.) increased from $2000 \mathrm{~kg}$ $\mathrm{ha}^{-1}$ to $6000 \mathrm{~kg} \mathrm{ha}^{-1}$ when irrigation was increased from 274 to $507 \mathrm{~mm}$ water.

The two macronutrients affected by water availability are N and P. Drought condition leads to reduced $\mathrm{N}$ mineralization and thus poor nitrogen absorption (Tisdale, 1993). Robinson (1957) found that rates of ammonification were reduced by one half when water potential decreased to the wilting point. Rates of ammonification and nitrification were also affected by soil moisture content (Reichman et al., 1966). Olsen and coworkers (1965) found a $50 \%$ decrease in P uptake by corn seedlings when soil water potential decreased from $-33 \mathrm{kPa}$ to -300 $\mathrm{kPa}$. Low soil moisture also induces Mn and Mo deficiencies while high soil moisture induces Fe and $\mathrm{Zn}$ deficiencies (Tisdale, 1993).

Water is an important factor which governs several morphological and biochemical change in plants and thus alters the overall quality. Plants respond to water stress either through tolerance or avoidance mechanisms. Avoidance involves stomata closure, loss of hydraulic conductance and increased root growth patterns; tolerance involves osmotic adjustments, changes in tissue elasticity and modification of protein and amino acid metabolism resulting in the storage of amino acids and sugars in leaves (Jones et al., 1981; Ranieri et al., 1998). According to Linn and Martin (1999), "water stress reduces plant growth, increases the leaf: stem ratio, digestibility, and anti-quality factors". Deetz et al., (1996) reported an increase in cell wall thickness and rigidity under water stress conditions. Nitrate accumulation is also induced in forage grasses in water stress conditions Kugler (2004, p.3). 
To better understand the effect of soil moisture on forage quality, the factors leading to changes in quality must be understood. Volaire and Thomas (1995) investigated the mechanism underlying the survival under prolonged soil moisture deficit, of drought resistant (KM2) and susceptible (Lutetia) populations of Dactylis glomerata. They found that drought resistant populations survived prolonged moisture deficit by slowing their growth rate. They also observed a greater root density, higher osmotic adjustments in leaf base, higher concentration of water soluble carbohydrates (WSC) in tiller base, lower proline: amino acid ratio, and lower leaf metal ion concentration in the drought resistant population than in the susceptible one. Water soluble carbohydrate export from dying leaves was also found to increase while maintaining a higher phosphorus status in the resistant population.

In order to explain water deficit effects on osmotic adjustment in leaves of annual clovers, Iannucci and co workers (2002) found that lowering of osmotic potential was mainly due to an increase of organic and inorganic solutes. They found that under water stress conditions, concentration of potassium, reducing sugars and proline increased while the concentrations of non reducing sugars decreased.

Nielsen (2004) studied the yield and quality response of kenaf forage under varying water availability conditions and found a linear relationship between dry matter (DM) yield and available water. The DM increased from $2000 \mathrm{~kg} \mathrm{ha}^{-1}$ to $6000 \mathrm{~kg} \mathrm{ha}^{-1}$ when water use was increased from $274 \mathrm{~mm}$ to $507 \mathrm{~mm}$. Fresh cuttings (1 cut and 2nd cut) of kenaf showed an increase in both neutral detergent fiber (NDF) (229 to $478 \mathrm{~g} \mathrm{~kg}^{-1}$ ) and acid detergent fiber (ADF) (168 to $314 \mathrm{~g} \mathrm{~kg}^{-1}$ ) concentration upon increase in water use. However crude protein (CP) declined in response to increasing water applications. A similar trend in dry matter production 
and water use was found for three other forage crops, corn (Zea mays L.), foxtail millet (Setaria italica L. Beauv.) and winter triticale (X Triticosecale Wittmack) (Nielsen et al., 2006). Philipp et al., (2005) also reported a similar trend in forage nutritive value of three old world bluestems under three different irrigation levels (low, medium and high). Irrespective of species, TNC and dry matter digestibility was found to decrease while NDF and ADF increased with increasing irrigation.

In an attempt to better define the effect of soil moisture deficits on forage quality of four species/cultivar (Trifolium ambiguum- culivars: Endura and Rhizo; Medicago sativa L, and Trifolium pratense L.), Seguin and coworkers (2002) found the same response regardless of species/cultivar. No interaction was found between species and soil water regimes. Moisture deficit conditions led to increased digestibility of all species owing to a decrease in ADL concentration. However, ADF concentration increased in all species/cultivars. They also found a minor effect of soil moisture deficit on different protein fractions.

Dietary proteins are classified according to the rate of their digestibility in the rumen. Non protein nitrogen (NPN) degrades instantaneously while true protein (TP) differs based on the proportion of different fractions $(\mathrm{B} 1>\mathrm{B} 2>\mathrm{B} 3)$. B1 is the soluble protein in fresh pasture and is degraded most rapidly. The $\mathrm{C}$ fraction is the non degradable portion (Sniffen et al., 1992). Seguin and coworkers (2002) found a lower proportion of NPN and a higher proportion of TP in kura clover and red clover than alfalfa under water deficits. However fraction $\mathrm{C}$ and acid detergent insoluble protein (ADIP) was lowest in kura clover. Thus protein fractions behaved differently among species/cultivar however the effect was relatively minor. 
Philipp et al., (2006) studied the influence of irrigation on mineral concentrations in three old world bluestem species and found that concentrations of $\mathrm{P}, \mathrm{S}, \mathrm{Al}, \mathrm{Fe}, \mathrm{Cu}$ and $\mathrm{Zn}$ (averaged across species) grown under dryland condition were greater than those under irrigated condition. Concentrations of $\mathrm{Mg}$ and $\mathrm{Zn}$ increased linearly with increasing irrigation while Fe concentration decreased linearly. However, they didn't find any influence of irrigation on concentrations of Ca, $\mathrm{S}, \mathrm{Al}$ and $\mathrm{Na}$.

\subsection{Soil Acidity}

Soil acidity is another factor limiting soil productivity in WV. A soil is called acidic when $\mathrm{pH}$ of the soil falls below 7.0. Soil acidity is generated by several natural and anthropogenic processes. Some of these are acid drainage in mine spoil from pyrite oxidation (Longhurst, 1991; Evangelou, 1995), rainfall and leaching, organic matter decay (Johnson and Zhang, 2010), plant induced acidity arising from nitrification (Nye, 1981), ammonium assimilation and ammonia volatilization (Bolan et al., 2003). The main cause of acidification in WV pasture soils is rainfall in excess of evapotranspiration, and the subsequent eluviations of $\mathrm{Ca}$ and Mg (Ritchey and Snuffer, 2002). There are four main forms of soil acidity: active, replaceable, residual and potential (Skousen and McDonald, 2005). Active acidity relates to the part of acidity which can be measured by a pH meter and can be neutralized quickly upon liming. Replaceable acidity is loosely held hydrogen, aluminum and iron which exist on colloids at the soil-solution interface. Residual acidity corresponds to the tightly bound hydrogen, aluminum and iron on soil surface and potential acidity is associated with the nature of the soil parent material and often results from oxidation of sulphide bearing minerals (Skousen and McDonald, 2005). Lime requirement is thus the amount of lime required to neutralize the acidity and bring 
the soil to a target $\mathrm{pH}$. Thus two soils may have the same soil $\mathrm{pH}$ but different lime requirements depending upon the prevalent form of soil acidity.

Soil acidity reduces the overall agronomic yield by decreasing the number of plant species in grasslands and reduces the nutritional quality of forage (Goulding and Annis, 1998; Tilman et al., 1994). Plant Ca and Mg concentration are decreased and concentrations of Al, Mn and Fe are increased in shoots and roots (Keltjens and Dijkstra, 1991). In soils, the available pool of alkali $(\mathrm{K})$ and alkaline earth cations $(\mathrm{Ca}$ and $\mathrm{Mg}$ ) is reduced and the pool of potentially toxic $\mathrm{Al}$ and Mn cations is significantly increased (Ulrich, 1994). The conditions for nitrogen fixation and phosphate availability also become less favorable (Truog, 1948). Root growth is retarded (Beegle and Lingenfelter, 1995; Johnson and Zhang, 2010) which reduces the uptake and translocation of $\mathrm{P}$ and $\mathrm{Mg}$ (Chen and Barber, 1990). Nutritional disorders are induced in plants (Carver and Ownby, 1995) and eventually results in either complete crop failure or significant yield loss. Animals grazing on such farmland are also susceptible to many nutritional disorders such as hypomagnesmic tetany, osteomalacia, rickets, and ataxia (Goff, 2010; Ammerman and Goodrich 1983).

Aluminum is among the major causes of soil acidity. Aluminum is insoluble above $\mathrm{pH}$ 5.5 and thus is not toxic to plants, but as soon the $\mathrm{pH}$ drops to 4.5 , the availability of aluminum increases 1000 times. As Al occupies a greater proportion of cation exchange sites available Ca, $\mathrm{Mg}, \mathrm{K}, \mathrm{NH}_{4}$, and $\mathrm{Na}$ are decreased (Bolan et al., 2003). Aluminum in aqueous solution reversibly and rapidly hydrolyzes to produce monomeric complexes and in the process generates $\mathrm{H}^{+}\left(\mathrm{H}_{3} \mathrm{O}^{+}\right)$. The $\mathrm{H}^{+}$generated binds to clay surfaces and generates additional $\mathrm{Al}^{+}$by dissolution (Bolan et al., 2003). The hydrolysis of $\mathrm{Al}$ forming monomeric species can be written as 
$\left[\mathrm{Al}\left(\mathrm{H}_{2} \mathrm{O}\right)_{6}\right]^{3+} \Leftrightarrow\left[\mathrm{Al}(\mathrm{OH})\left(\mathrm{H}_{2} \mathrm{O}\right)_{5}\right]^{2+}+\mathrm{H}_{3} \mathrm{O}^{+}$

$\left.\left[\mathrm{Al}(\mathrm{OH})\left(\mathrm{H}_{2} \mathrm{O}\right)_{5}\right]^{2+} \Leftrightarrow[\mathrm{ArOH})_{2}\left(\mathrm{H}_{2} \mathrm{O}\right)_{4}\right]^{1+}+\mathrm{H}_{3} \mathrm{O}^{+}$

$\left[\mathrm{Al}(\mathrm{OH})_{2}\left(\mathrm{H}_{2} \mathrm{O}\right)_{4}\right]^{+1} \Leftrightarrow\left[\mathrm{Al}(\mathrm{OH})_{3}\left(\mathrm{H}_{2} \mathrm{O}\right)_{3}\right]^{0+}+\mathrm{H}_{3} \mathrm{O}^{+}$

$\left[\mathrm{Al}(\mathrm{OH})_{3}\left(\mathrm{H}_{2} \mathrm{O}\right)_{3}\right]^{0} \Leftrightarrow\left[\mathrm{Al}(\mathrm{OH})_{4}\left(\mathrm{H}_{2} \mathrm{O}\right)_{2}\right]^{-1}+\mathrm{H}_{3} \mathrm{O}^{+}$

Liming is a common practice to reduce the activity of $\mathrm{Al}$ (and $\mathrm{Mn}$ ) and thus remediate soil acidity (Beegle and Lingenfelter, 1995). Upon liming, $\mathrm{Al}^{3+}$ is displaced from the exchange complex and precipitates as unavailable hydroxides. The complete neutralization reaction can be written as

$$
\mathrm{ExAl}+\frac{3}{2} \mathrm{CaCO}_{3} \stackrel{\mathrm{H}_{2} \mathrm{O}}{\longrightarrow} \mathrm{Al}(\mathrm{OH})_{3}+\frac{3}{2} \mathrm{ExCa}+\frac{3}{2} \mathrm{CO}_{2}
$$

Not only does liming recharge the soil with $\mathrm{Ca}$ and $\mathrm{Mg}$, it increases the soil $\mathrm{pH}$ and thus increases the plant available $\mathrm{Ca}, \mathrm{Mg}, \mathrm{N}$ and $\mathrm{P}$. This results in increased forage yield (Beegle and Lingenfelter, 1995; Zhang et al., 2004; Moschler et al., 1973; Arshad and Gill, 1996). Nyborg and Hoyt (1978) observed an increase in nitrogen availability upon liming. Lyngstad (1992) found a considerable increase in organic $\mathrm{N}$ mineralization when soil was limed to $\mathrm{pH}$ 7. Higher $\mathrm{P}$ concentrations were observed in leaf of soybean, sunflower and beans when soils received lime applications (Van Raij and Quaggio, 1990).

Several liming agents can be used to correct soil acidity each with a unique concentration of $\mathrm{Ca}$ and $\mathrm{Mg}$. Although liming agents such as calcite $\left(\mathrm{CaCO}_{3}\right)$, dolomite $\left(\mathrm{Ca} \mathrm{Mg}\left(\mathrm{CO}_{3}\right)_{2}\right)$, burnt lime $(\mathrm{CaO})$, and slaked lime $\left(\mathrm{Ca}(\mathrm{OH})_{2}\right)$ are used, the effects of Ca: $\mathrm{Mg}$ ratio on forage quality parameters deserves to be explored in more detail. Ritchey and Snuffer (2002) found that on 
"acidic hill-land soils" Mg supplementation was necessary for establishment and higher production of orchardgrass (Dactylis glomerata L.) and tall fescue (Festuca arundinacea Schreb). They found that the application of gypsum resulted in a decreased soil and plant $\mathrm{Mg}$ concentrations and induced $\mathrm{Mg}$ deficiency.

Other benefits associated with evaluating the Ca:Mg ratio of liming agents are to limit the undesirable effects of overliming especially those of phosphorous and micronutrient deficiencies (Kamprath, 1971) and to predict the availability of macronutrients (N, P, K, Ca, Mg). At different ranges of Ca:Mg, Keltjens and Dijkstra (1991) found that Mg was more effective in increasing the drymatter yield in $\mathrm{Al}$ stressed wheat (Triticum aestivum). The relative yield increased from $15 \%$ to $105 \%$ when the $\mathrm{Mg}$ concentrations were increased from $0.25 \mathrm{mM}$ to 5 $\mathrm{mM}$. They suggested that aluminum induced growth inhibition was due to Mg deficiency and that higher Ca depressed the Mg uptake.

\subsection{Soil Test Interpretations}

Research carried out in early 1950 provides evidence for the effects of soil saturation percentage of $\mathrm{Ca}$ and $\mathrm{Mg}$ on crop response. Soils with exchangeable sites containing $65 \% \mathrm{Ca}$, $10 \% \mathrm{Mg}, 5 \% \mathrm{~K}$, and $20 \% \mathrm{H}$ were found best for alfalfa plants (Bear and Toth, 1948). Similarly the yield of sudangrass and ladino clover were found to decrease when soil exchangeable $\mathrm{Mg}$ was below 4\% of CEC (Adam and Henderson, 1962). McLean and Carbonell (1972) also found an increase in alfalfa yield when $\mathrm{Mg}$ and Ca saturations were increased from 3 and $18 \%$ to 5 and $75 \%$ respectively. Plant tissue $\mathrm{Mg}$ concentration also increased with increasing soil $\mathrm{Mg}$ saturation. However, Van Itallie (1948) suggested that plant uptake of cations is also related to its comparative abundance with respect to other soil cations. Calcium:magnesium ratio was a 
topic of debate among researchers and they were interested in finding the best soil $\mathrm{Ca}$ and $\mathrm{Mg}$ ratio for optimal yield .Two schools of thought evolved to contrast the importance of lime/fertilizer recommendations in regards to nutrient status and plant response. One school promoted the sufficiency level of available nutrients (SLAN) where the other emphasized the importance of basic cation saturation ratio (BCSR) (Haby et al., 1990; McLean, 1977).

The SLAN concept advocated the idea of maximal plant growth under sufficient soil nutrient condition. Growth/yield declines proportionately when toxicity levels are present. Thus fertilization depends on plant's need (Eckert, 1987). Most soil testing laboratories use the SLAN method to make fertilizer recommendations.

The BCSR concept on the other hand claimed to fertilize according to the soil's need (Eckert, 1987). The balanced ratio of basic cations $\left(\mathrm{Ca}^{2+}, \mathrm{Mg}^{2+}\right.$, and $\left.\mathrm{K}^{+}\right)$for the soil's cation exchange capacity (CEC) must be maintained to ensure proper plant growth (McLean, 1977). The suggested ratio falls within 65 to $85 \% \mathrm{Ca}, 6$ to $12 \% \mathrm{Mg}$, and 2 to $5 \% \mathrm{~K}$ of saturation percentage of the CEC (Graham, 1959).

Another concept behind "balanced soil" was to minimize the luxury consumption of nutrients, especially K. Bear and coworkers found that a "high Ca saturation percentage limits luxury K uptake”. However other researchers (McLean and Carbonell, 1972; Liebhardt 1981) found the concept of balanced soil to be flawed and that the yield was not influenced by the ratio of Ca: Mg. Smith and Albrecht (1942) on the other hand proposed that crops grown in "unbalanced soils" would have poor nutritional quality.

Most of the attempts by early researchers (Loew and May, 1901; Albrecht, 1975; Graham, 1959) to establish soil Ca: Mg ratio ideal for optimum plant growth were quite 
misleading. For example, a soil with exchangeable $\mathrm{Ca}$ and $\mathrm{Mg}$ levels of 200 and $50 \mathrm{~b} / \mathrm{a}$, respectively, would be marginally low where as a soil with 2000 and $500 \mathrm{lb} / \mathrm{a}$ of exchangeable $\mathrm{Ca}$ and $\mathrm{Mg}$ would be exceptionally high for plant growth and development, although both represent a Ca: $\mathrm{Mg}$ ratio of 4:1. Also, a soil with low $\mathrm{Ca}: \mathrm{Mg}$ ratio might be interpreted as having low exchangeable $\mathrm{Ca}$ and normal $\mathrm{Mg}$ or normal exchangeable $\mathrm{Ca}$ and high $\mathrm{Mg}$ and vice versa (Schulte and Kelling, 1993). Soil mineralogy and cation exchange capacity also vary widely with region and soil parent material and this adds variability to the existing $\mathrm{Ca}$ and $\mathrm{Mg}$ present in the soil. McLean and Carbonell (1972) failed to find any affect of $\mathrm{Ca} / \mathrm{Mg}$ saturation (Ca 75\%-55\%;

Mg 5\%-25\%) on German millet (Setaria italic German) and alfalfa (Medicago sativa) yield. However they found that by increasing the initial $\mathrm{Mg}$ saturations from 3 to $18 \%$ and $\mathrm{Ca}$ saturation from 5 to $75 \%, \mathrm{pH}$ of soil increased from 4.5 to 6.8 and alfalfa yield doubled.

\subsection{Calcium and Magnesium}

Because $\mathrm{Ca}$ and $\mathrm{Mg}$ are involved in several plant physiological processes, different ratios $\mathrm{Ca}: \mathrm{Mg}$ in the liming agent to achieve a target $\mathrm{pH}$ may have an effect on forage yield and quality. The entire above stated syllogism can be redefined by considering the amount of lime required to bring the optimum $\mathrm{pH}$ (specific for each crop) and finding the best ratio of $\mathrm{Ca}$ and $\mathrm{Mg}$ in the liming agent which gives the optimum yield. Use of a liming agent with the best $\mathrm{Ca}$ : $\mathrm{Mg}$ ratio will have several effects. Not only will it increase the soil $\mathrm{pH}$, but it will also increase the $\mathrm{Ca}$ and $\mathrm{Mg}$ saturation percentage of the exchange sites and thus the plant available levels of $\mathrm{Ca}$ and $\mathrm{Mg}$. This will also reduce the limitation imposed by soil acidity conditions (Al, Fe, Mn toxicity) to plant growth, beside maximizing returns and minimizing the cost of production. There is a 
significant amount of information in the literature about the role of $\mathrm{Ca}$ and $\mathrm{Mg}$ in the plant's physiological process such as photosynthesis, disease tolerance, protein synthesis etc.

Calcium is not usually limiting under field conditions but deficiency of this ion may cause poor root development, leaf necrosis and curling, blossom end rot, bitter pit, poor fruit storage and water soaking (Simon, 1978; White and Broadley, 2003). Calcium is identified as an essential secondary macronutrient and plays an important role in cell wall formation and the cellular membrane system. Bangerth (1979) defined four important biological functions of $\mathrm{Ca}$ in plants. He attributed these functions as effects on membranes, effects on enzymes, effects on cell walls and the interaction effects on phytohormones. Williams (1976) attributed these unique functions of $\mathrm{Ca}$ to its coordination ability and proposed the action of $\mathrm{Ca}$ as a "function of its concentration, binding strength, structure (of Ca and ligand), and rate constants".

An important role of $\mathrm{Ca}$ was found in signal transduction and expression of heat shock proteins (HSP). Heat shock proteins are a class of protein which helps the plant to cope with elevated temperature (Queitsch et al., 2000; Burke 2001). In an attempt to study the regulation of $\beta$-glucuronidase (GUS) activity which helps in expression of HSP, Liu et al., (2005) found that addition of $\mathrm{CaCl}_{2}$ up- regulated the level of $\beta$-glucuronidase (GUS) activity in transgenic Arabidopsis..

Calcium also stimulates the protein channels for uptake and movement of nutrients into the root and throughout cells within the plants. Hence $\mathrm{Ca}$ is required in adequate amount at the root surface for efficient regulation of this protein pump (Patterson, 2010).Toxic amounts of $\mathrm{Al}$ (above $400 \mathrm{ppm}$ ) reduce root efficiency by reducing $\mathrm{Ca}$ and $\mathrm{Mg}$ availability (Patterson, 2010). 
Another important role of $\mathrm{Ca}$ was found in combating pathogen attack. The calcium ion is present in greatest concentrations in the cell wall (Rossignol et al., 1977) and presumably dictates several properties associated with it. Among these, cell wall stabilization to maintain structural rigidity is an important one. This unique property can be ascribed to the tight binding of calcium ions to the pectin molecules via cross link formation in the cell wall (Burstorm, 1968; Demarty et al., 1984). In contrast to this, a low $\mathrm{Ca}^{2+}$ supply makes the cell wall more pliable and easily ruptured. It has been found that Ca deficiency decreased cell wall rigidity and makes the plant susceptible to disease or pest attack (Patterson, 2010). Pathogens attack cell tissue by secreting pectinase which dissolves pectin. Thus higher pectin concentration helps to combating disease (Patterson, 2010).

In an attempt to locate $\mathrm{Ca}$ in histological sections of plants, several researchers (Kramer et al., 1980; Campbell et al., 1979; Rossignol et al., 1977) found the greatest concentration of $\mathrm{Ca}^{2+}$ in the cell wall. The cell wall can be divided into three subunits-primary cell wall, secondary cell wall and middle lamella. The primary cell wall is formed when a cell is growing, while the secondary wall develops inside it once the cell has stopped growing. The middle lamella is present between two adjacent cells and has gel like properties which hold the neighboring cells together. Polysaccharides such as pectic acid are the main components of these gels. Just as the gelling of a solution of free algin or pectin is induced by the $\mathrm{Ca}^{2+}$ ions (Tepfer, 1981), in the same way $\mathrm{Ca}^{2+}$ affinity for the uronic group can induce inter-chain associations of pectin molecules. Thom et al., 1982 outlined the mechanism of " $\mathrm{Ca}^{2+}$ induced inter-chain associations" through his circular dichroism and equilibrium dialysis experiments. He proposed that in the first step, the two homopolymers of pectin components unite to form a dimer and $\mathrm{Ca}^{2+}$ is sandwiched between the inner faces of both monomeric components. Stepwise binding takes 
place in a cooperative mechanism concatenating two chains and thus facilitating further $\mathrm{Ca}^{2+}$ fixation. Wuytaek and Gillet (1978) through their conductance and ionic exchange measurements also predicted the nature of $\mathrm{Ca}$ linkage in the cell wall. They suggested that $\mathrm{Ca}^{2+}$ ions associate in the cell wall by electrostatic interactions with the carboxylic groups as well as coordination linkages with the hydroxyl groups of diverse polysaccharides. One might argue that pectin molecules can also be linked through hydrogen bonding rather than $\mathrm{Ca}^{2+}$ cross linking. But the unique three dimensional axis of pectic polysaccharides does not permit hydrogen bonding. So the only option left is $\mathrm{Ca}^{2+}$-cross bridges (Demarty et al., 1984). Exchange experiments carried out on isolated cell walls also exhibited selected preferentially for $\mathrm{Ca}^{2+}$ over monovalent ions. (Sentenac and Grignon, 1981; Dainty and Hope, 1961; Demarty et al., 1978).

The most common function of $\mathrm{Mg}$ is related to its presence in chlorophyll (30\% of total plant $\mathrm{Mg}$ ) and its role in photosynthesis. Magnesium acts as a bridging element and forms complexes of different stabilities. Magnesium forms ternary complexes with enzymes such as RuBP carboxylase (Pierce, 1986) and also acts as an activator of many other enzymes such as ATPases, RNA polymerase and protein kinases (Marschner, 1995; Shaul, 2002).Magnesium acts as a bridging element for the aggregation of ribosomal subunits (Marschner, 1995). At least $25 \%$ of the total protein is localized in leaf chloroplasts. A magnesium deficiency immediately stops net RNA synthesis and enhances the rate of protein degradation, explaining why $\mathrm{Mg}$ deficiency symptoms appear first in mature leaves (Marschner, 1995). Magnesium is also associated with carbohydrate partitioning. Magnesium deficiency results in accumulation of carbohydrates in Mg-deficient leaves (Cakmak, 2008). 
Liming acid soils not only improves the soil $\mathrm{pH}$ but also provides better growing conditions resulting in an overall increase in yield and nutritional quality. According to Kugler (2004, p.4) "Small increases in both voluntary intake and dry matter digestibility have been observed when calcium is applied to deficient soils". Zhang et al., (2004) investigated the effect of liming rates on the yield and quality of winter wheat forage (Triticum aestivum L.) grown in a field with initial $\mathrm{pH}$ of 4.5 . They found that with an increase in $\mathrm{pH}(\sim 6.8)$ forage yield doubled in the first year (liming rate $>1.25$ tons/acre). However they did not find any significant response in protein and mineral nutrient concentration of forage in the early vegetative stage.

Caddel et al., (2004) studied the yield and persistence response of alfalfa (Medicago sativa), red clover (Trifolium pratense), and white clover (T. repens) to soil $\mathrm{pH}$ and five lime treatments and found that the yields of red clover and alfalfa increased significantly with increasing $\mathrm{pH}$ while legume stand density and stand persistence remained unaffected. Bolland et al., (2001) evaluated the yield response of subterranean clover (Trifolium subterranean cv Trikkala) and Italian rye grass (Lolium multiflorium cv Aristocrat) to five different lime rates (0, 2.5, 5.0, 7.5, 10, 12.5 ton lime/Ha) on a loamy (initial $\mathrm{pH} 4.4$ ) and sandy soil (initial $\mathrm{pH}$ 4.3).They found that herbage yield increased linearly with lime rate from 16 to $53 \%$, however they didn't find any significant increase in concentration of nutrient elements except for the concentration of $\mathrm{Ca}$ which increased with increasing lime rate. Also they did not find any effect on dry matter digestibility, or concentrations of metabolizable energy, crude protein or watersoluble carbohydrates in dried herbage at any of the harvest dates.

Although forage nutritional responses vary widely with soil chemical and physical properties yield response to liming was consistent in all the experiments. The crop response to a 
particular nutrient ( $\mathrm{Ca}$ and $\mathrm{Mg}$ in this case) depends on its concentration and activity in the soil solution and the capacity of the soil to replenish the nutrient in the soil solution. The source of the nutrient also affects the availability as well as its activity in the soil solution. In an attempt to find the effect of different $\mathrm{Mg}$ fertilizers sources on $\mathrm{Mg}$ availability in soils, Hardter et al., (2004) found that dry matter yield of maize increased significantly with increasing fertilizer rates and sources as compared to control. Magnesium removal by plants was also affected by $\mathrm{Mg}$ source as well as $\mathrm{Mg}$ rates. However the availability of $\mathrm{Mg}$ also depends on its relative proportion compared to exchangeable amounts of $\mathrm{Ca}, \mathrm{Al}, \mathrm{K}$ and $\mathrm{Mn}$ present in soil. Some of the researchers investigated the effect of $\mathrm{Ca}: \mathrm{Mg}$ to yield response of crops.

Osemwota et al., (2007) investigated the effect of Ca: $\mathrm{Mg}$ ratio on yield and yield components of maize in both green house and field. Optimal yield was attained at an exchangeable $\mathrm{Ca} / \mathrm{Mg}$ ratio between 2:1 and 3:1 under greenhouse conditions whereas under field conditions the optimal yield was achieved at a ratio of 6:1. They also found a positive and significant correlation between the observed $\mathrm{Ca} / \mathrm{Mg}$ ratio in soil and plant tissue. Magnesium concentration in plant tissue decreased while Ca concentration increased with increasing $\mathrm{Ca} / \mathrm{Mg}$ ratio. In soil, Ca concentration was positively correlated whereas $\mathrm{Mg}$ concentration was negatively correlated with $\mathrm{Ca} / \mathrm{Mg}$ ratio. However, they didn't find any significant response in plant height, stem girth, earleaf, number of leaves, cob field weight, grain yield, and $\mathrm{Ca}$ and $\mathrm{Mg}$ concentrations of earleaf with regards to $\mathrm{Ca} / \mathrm{Mg}$ treatments. Also there were differences in field response compared to the greenhouse response. 


\subsection{Forage Quality}

Reports of several researchers have indicated that forage quality depends on factors such as maturity, genotype, plant morphology, season, soil fertility and soil moisture (Hall, 2004; Piaggio and Prates, 1997; Balasko, 1977). We will limit our discussion to soil moisture and fertility effects (especially liming practices) on forage quality for this paper.

Forage quality includes forage nutritive value as well as intake, digestibility and partitioning of metabolized products within animals (Buxton, 1996). According to Ball et al., (2001) forage quality is defined as the extent to which forage has the potential to produce a desired animal response. Forage constitutes about $90 \%$ of fiber in ruminant diets (Ball et al., 2001). The term fiber is more often used to refer to cell walls. Animals lack enzymes for hydrolyzing the components of cell walls. Ruminants depend on microorganisms present in their gastrointestinal tract to ferment and utilize cell wall as their nutrient source (Van Soest, 1994).The composition of the cell wall determines its suitability as a forage crop. Several families of flowering plants are used to feed livestock. Among them fabacae (legumes) and poaceae (grass) are most important. In WV grass-clover mixtures are the most important forage combinations (Lozier et al., 2004).

Higher polysaccharide concentration in forage is good indicator of forage quality hence the paradigm must be shifted on increasing their concentration in the forage species. One way to approach this thought would be the refinement of agronomic practice associated with raising forage crops. Finding the link between factors governing cell wall composition in context to plant nutrition through application of lime and fertilizer would be a good start. 
Early researchers assessed forage quality based on forage yield, late maturity, disease resistance and animal palatability criteria (Casler and Vogel, 1999).Today we have improved laboratory techniques to better assess forage quality. Advancement over proximate analysis several lab techniques such as, acid detergent fiber (ADF), neutral detergent fiber (NDF), acid detergent lignin (ADL), crude protein (CP), and total non structural carbohydrates (TNC) are better indicators of forage quality (Undersander, 2004). A low quality forage is characterized by higher lignin, phenolics, silica, cutin, certain proteins, and water whereas high quality forage is characterized by higher content of organic acids, proteins, lipids, soluble minerals, and nonstructural carbohydrates (Asay et al., 2002).

The cell wall can be divided into primary cell wall, secondary cell wall and middle lamella (Figure1) and is chiefly composed of cellulose, non cellulosic polysaccharides (mannans, galactans, xylans, arbans), hemicelluloses, pectic substances (pectins, pectic acid and protopectic substances) water and mineral. Other wall components such as lignin and glycoprotein may also be present depending on cell type, plant age and plant species. The cell wall can also be visualized as a network of cellulose microfibrils embedded in an amorphous gel composed of a range of polysaccharide (Hatfield, 1989). The proportion and composition of the cell wall components vary widely between plant species (Harris, 2005) and also affect the digestibility in ruminant animal mainly because of differences in degree of hydrogen bonding of individual polysaccharides, branching patter and association with other wall components (Hatfield, 1989). Presence of a significant amount of lignin poses a barrier to rumen degradation of polysaccharides. Hence lignified secondary walls are less digested than primary wall (Jung and Allen, 1995). 
Neural detergent fiber can be best viewed as an estimate of total cell wall, which is comprised of the ADF fraction plus the hemicelluloses (Collins and Fritz, 2003). Neutral detergent fiber values are important in ration formulations because they reflect the amount of forage the animal can consume. As NDF percentages increase, dry matter intake decreases because of the filling effect. The filling effect of forage is directly related to its cell wall concentration and the rate of their digestion in rumen. Forage with a higher NDF value has a higher filling effect (Buxton, 1996). Thus, forages with low NDF will have a higher intake than those with a high NDF.

In general, legumes tend to have lower NDF values than grasses and have more rapid digestion rates (Henning et al., 1995; Buxton, 1996). Neural detergent fiber concentrations also vary within plant parts. Buxton (1996) reported that NDF concentration in stems $\left(700 \mathrm{~g} \mathrm{~kg}^{-1}\right)$ was higher than leaves $\left(500 \mathrm{~g} \mathrm{~kg}^{-1}\right)$ in four cool season grasses - orchardgrass (Dactylis glomerutu L.), smooth bromegrass (Bromus inermis Leyss.), tall fescue (Festuca arundinacea Schreb.), and reed canarygrass (Phalaris arundinacea L). Digestibilty of the plants parts followed the order: top leaves $\left(650 \mathrm{~g} \mathrm{~kg}^{-1}\right)>$ bottom leaves $\left(550 \mathrm{~g} \mathrm{~kg}^{-1}\right)>$ top stem $\left(550 \mathrm{~g} \mathrm{~kg}^{-1}\right)>$ bottom stem $(500 \mathrm{~g}$ $\mathrm{kg}^{-1}$ ) (Buxton and Marten, 1989).

Conceptually, $\mathrm{ADF}$ is the percentage of indigestible plant material present in forage. It contains cellulose, lignin, and silica (Van Soest et al., 1991). ADF value is important because they relate to the ability of an animal to digest the forage and can be used to predict energy value. As ADF increases, digestibility of forage usually decreases (since lignin and silica, which are components of ADF, cannot be digested by ruminants). Therefore, low ADF values are desirable (Henning, et al., 1993). 
Lignin plays an important role in water conduction, providing strength to fibrous tissues and limiting the entry of pathogens in to plant tissue (Iiyama et al., 1994). Lignin is a polymer formed from monolignols derived from the phenylpropanoid pathway in vascular plants (Moore, 2001). It is deposited in the cell walls of plants during cell maturation. As the cell differentiates lignification increases in structural tissues (xylem and sclerenchyma). As plants mature, the relative proportion of lignified tissues increase. Since lignin interferes with digestion of cell wall polysaccharides (by posing a physical barrier to microbial enzymes) it is considered an antiquality factor in forages. Environmental factors such as temperature, soil moisture, light and soil fertility affect the extent of lignification (Moore, 2001). As lignin concentration increases, digestibility, intake, and animal performance usually decrease and the percent ADF and NDF increase (Schroeder, 1994).

Protein is required by animals for growth, body maintenance and milk production and is usually expressed as crude protein percentage. Crude protein is the sum of true protein and nonprotein nitrogen and is the second most limiting nutrient for the ruminant animal. True protein includes nitrogen present in peptides, amino acids, etc. True protein is difficult to determine routinely hence CP is used to characterize the nutritional value of feed/ forage (Hintz, 1995). Crude protein is estimated by measuring the nitrogen concentration and multiplying by 6.25 . In general $\mathrm{CP}$ of legumes is higher than grasses. Also, $\mathrm{CP}$ of the leaf blade is higher than that of thestem (Buxton, 1989).

Pectins are linear polymers composed of D-galactopyranosyl uronic acid (GU) units, (Figure2) which are linked through $\alpha-1,4$ glycosidic bonds forming long chains of polygalacturonic acid (PGA). They also have small fractions of rhamnose and sugar units 
attached as side chains. Pectin plays a key role in plant primary cell wall's architecture, mainly because of their ability to bind to each other through calcium bridges. Pectins are found in highest concentration in the middle lamella of cell wall in leaves than stem and are arranged as branched, cross linked networks along with cellulose microfibrils (Figure1) (Hatfield and Weimer, 1995; Hall et al., 1997).

Pectins constitute 10 to $20 \%$ of the total carbohydrate complex in grasses and alfalfa (Lagowski, et al., 1958; Waite and Gorrod, 1959) and are highly digestible (Michaux, 1951). They are important in forages since they increase palatability and carbohydrate availability. Carbohydrate availability limits microbial activity and thus protein utilization in ruminants (Van Soest, 1995). Pectin degrades fairly rapidly and increases carbohydrate availability (Sniffen et al., 1992; Jung, 1996). Thus its higher concentration in forages improves digestibility and protein utilization (Hatfield et al., 1999; Van Soest, 1995; Viands, 1995; McCormick et al., 2001). Ariza et al. (2001) found that a citrus pulp based higher pectin diet better supported ruminal microbial growth. In another experiment Miron et al., (2002) found that partial replacement of citrus pulp (higher in pectin concentration) in the total mixed ration improved the feed utilization efficiency in dairy cows.

Three types of pectins are present in plant cell wall-homogalacturonan (HG), rhamnogalacturonan I (RG-I), and rhamnogalacturonan II (RG-II) (Ridley, et al., 2001). HG is a polymer of $\alpha-1,4$-linked galacturonic acid and accounts for $\approx 65 \%$ of pectin in the plant (Sun et al., 2005). Some of the carboxyl groups of the uronic acid units are esterified with methanol. The residual carboxyl groups are partly or completely bound to cations such as $\mathrm{Ca}$ or $\mathrm{Mg}$. The ratio of esterified D-GU acid groups to total galacturonic acid groups is termed the degree of 
esterification (DE). Based on the DE, pectins are categorized under two classes: high methoxyl (HM) pectins, and low methoxyl (LM) pectins. Conditions, within, gelation of lower DE pectins can be induced by $\mathrm{Ca}$ in vitro. The mechanism was described as the 'egg-box' model by Grant et al., (1973) (Figure 3). Gelation also depends on pH and media temperature (Capel et al., 2006). Specific sequences of Galacturonic acid monomers associate side by side and are linked through electrostatic and ionic bonding of carboxyl group. As the number of reactive carboxyl groups that can form a salt bridge increases, the chances that the bridge will be formed also increases. Furthermore, because of the larger number of charged groups, de-esterified molecules are straighter than the esterified ones, so they will more likely form calcium linkages (Thibault and Rinaudo, 1985). 


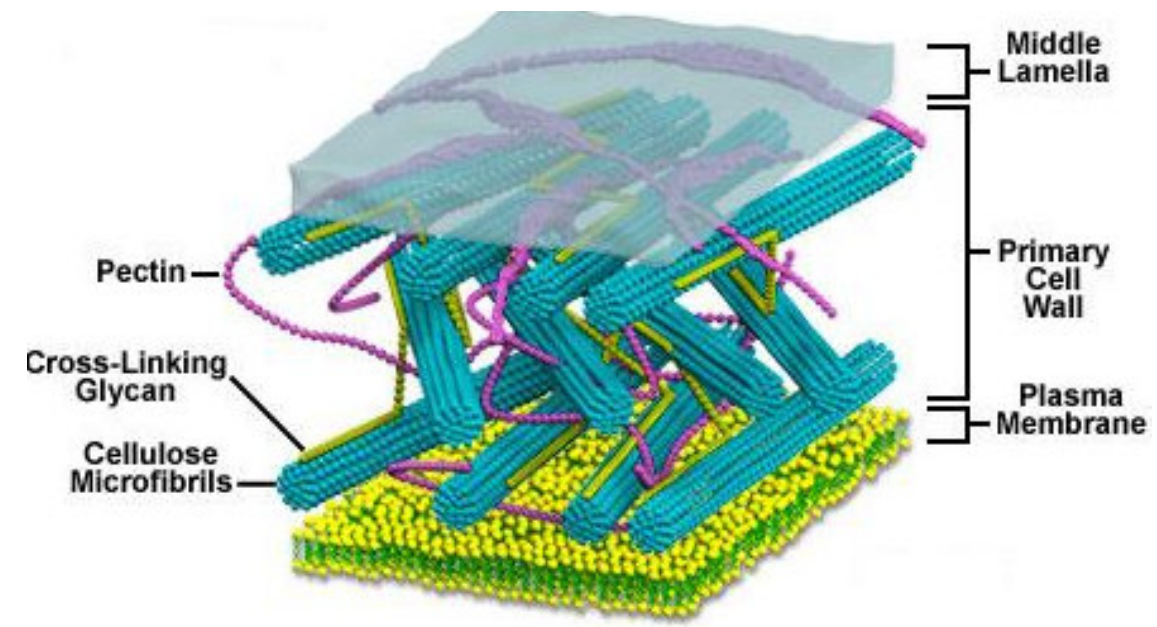

Figure 1. Cell wall diagram (Davidson, 1995) 


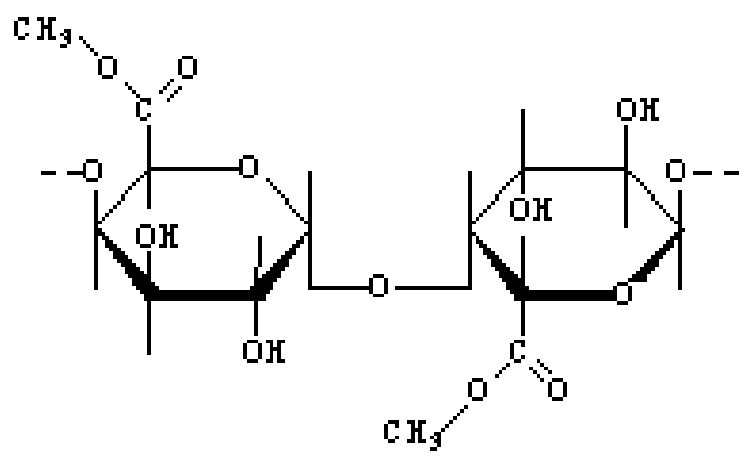

Figure 2. Schematic representation of Pectin (Hangarter, 2004). 

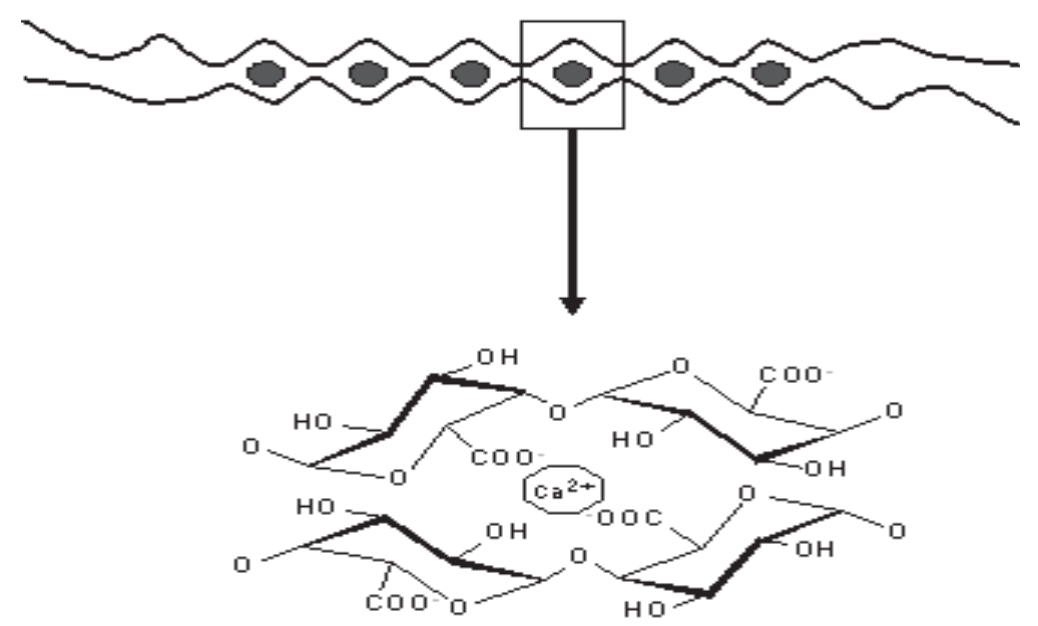

Figure 3. Schematic representation of calcium binding to polygalactoronate sequences: 'egg box' dimer and 'egg-box'cavity (Axelos \& Thibault, 1991). 


\section{References}

Adams, F. and J.B. Henderson. 1962. Magnesium availability as affected by deficient and adequate levels of potassium and lime. Soil Sci. Soc. Am. J. 26:65-68.

Albrecht, W.A. 1975. The Albrecht Papers vol. 1: Foundation Concepts. Acres, U.S.A, Kansas City.

Ammerman, C.B. and R.D. Goodrich. 1983. Advances in mineral nutrition in ruminants. J. Anim. Sci. 57:519-533.

Ariza, P., A. Bach, M.D. Stern and M.B. Hall. 2001. Effects of carbohydrates from citrus pulp and hominy feed on microbial fermentation in continuous culture. J. Anim. Sci. 79:2713.

Arshad, M.A. and K.S. Gill. 1996. Field pea response to liming of an acid soil under two tillage systems. Can. J. Soil Sci. 76:549-555.

Asay, K.H., D.A. Johnson, T.A. Monaco, G. Han, K.B. Jensen and B.L. Waldron. 2002. Forage quality of tall fescue across an irrigation gradient. Agron. J. 94:1337-1343.

Axelos, M.A.V., J.F. Thibault, C.M.G.C. Renard and C. Garnier. 1996. Interactions of pectins with multivalent cations: Phase diagrams and structural aspects. p. 35-45. In J. Visser and A.G.J. Voragen (eds.) Pectins and Pectinases. Elsevier Science, 1996, Wageningen, The Netherlands.

Balasko, J.A. 1977. Effects of N, P, and K fertilization on yield and quality of tall fescue forage in winter. Agron. J. 65:425-428. 
Ball, D.M., M. Collins, G.D. Lacefield, N.P. Maitin, D.A. Mertens, K.E. Olson, D.H. Putnam D.J. Undersander and M.W. Wolf MW. 2001. Understanding Forage Quality. American Farm Bureau Federation Publication 1-01: Park Ridge, IL: American Farm Bureau Federation.

Baligar, V.C., R.J. Wright, O.L. Bennett, J.L. Hern, H.D. Perry and M.D. Smedley. 1985. Lime effect on forage legume growth and mineral composition in an acid subsoil. Commun. Soil Sci. Plant Anal. 16:1079-1093.

Bangerth, F. 1979. Calcium related physiological disorders of plants. Ann. Rev. Phytopathol. 7:97-112.

Bear, F.E. and S.J. Toth. 1948. Influence of calcium on availability of other soil cations. Soil Sci. 65:69-75.

Beegle, D.B. and D.D. Lingenfelter. 1995. Soil acidity and aglime. [Online.] Available at http://cropsoil.psu.edu/Extension/Facts/AgFact3.pdf. (accessed 10 January, 2010) Rep. RV5M995. Penn State Cooperative Extension, PA.

Bolan, N.S., D.C. Adriano and D. Curtin. 2003. Soil acidification and liming interactions with nutrient and heavy metal transformation and bioavailability. Adv. Agron. 78:215-272.

Bolland, M.D.A., L.D. Osborne, L. Paszkudzka-Baizert and Z. Rengel. 2001. Responses of subterranean clover and italian ryegrass to application of lime. Aust. J. Exp. Agric. 41:177-185.

Boyer, D.G., R.J. Wright, W.M. Winant and H.D. Perry. 1990. Soil water relations on a hilltop cornfield in central Appalachia. Soil Sci. 149:383-392. 
Bronson, K.F., A.B. Onken, J.D. Booker, R.J. Lascano, T.L. Provin and H.A. Torbert. 2001. Irrigated cotton lint yields as affected by phosphorus fertilizer and landscape position. Commun. Soil Sci. Plant Anal. 32:1959-1967.

Burke, J.J. 2001. Identification of genetic diversity and mutations in higher plant acquired thermotolerance. Physiologia. Plantarum. 112:167-170.

Burstrom, H.G. 1968. Calcium and plant growth. Biol. Rev. (Camb.). 43:287-316.

Buxton, D.R. 1996. Quality-related characteristics of forage as influenced by plant environment and agronomic factors. Animal Feed Sci. Tech. 59:37-49.

Buxton, D.R. and G.C. Marten. 1989. Forage quality of plant parts of perennial grasses and relationship to phenology. Crop Sci. 29:429-435.

Caddel, J.L., K. Wise and H. Zhang. 2004. Responses of alfalfa, red clover, and white clover to soil $\mathrm{pH}$ and lime treatments. [Online.] Available at http://www.plantmanagementnetwork.org/pub/fg/research/2004/lime/. (accessed 12 January, 2010) Forage and Grazinglands.

Cakmak, I. and E.A. Kirkby. 2008. Role of magnesium in carbon partitioning and alleviating photooxidative damage. Physiol. Plantarum. 133:692-704.

Campbell, N.A., K.M. Stika and G.H. Morrison. 1979. Calcium and potassium in the motor organ of the sensitive plant: Localization by ion microscopy. Science 204:185-187.

Capel, F., T. Nicolai, D. Durand, P. Boulenguer and V. Langendorff. 2006. Calcium and acid induced gelation of amidated low methoxyl pectin. Food Hydrocoll. 20:901-907.

Carver, B.E. and J.D. Ownby. 1995. Acid soil tolerance in wheat. Adv. Agron. 54:117-173. 
Casler, M.D. and K.P. Vogel. 1999. Accomplishments and impact from breeding for increased forage nutritional value. Crop Sci. 39:12.

Chen, J.H. and S.A. Barber. 1990. Effect of liming and adding phosphate on predicted phosphorus uptake by maize on acid soils of three soil orders. Soil Sci. 150:844-850.

Collins, M. and J. O. Fritz. 2003. Forage quality. p. 363-390. In R.F. Barnes, C. J. Nelson, M. Collins and K. J. Moore. (eds.) Forages: An Introduction to Grassland Agriculture. 6th ed. Iowa State Press, Ames, Iowa.

Dainty, J. and A.B. Hope. 1961. The electric double layer and the Donnan equilibrium in relation to plant cell walls. Austr. J. Biol. Sci. 14:541-551.

Davidson, M.W. 1995 Plant Cell Wall [Online.] Available at. http://www.molecularexpressions.com/cells/plants/cellwall.html. (accessed 12 January, 2010). Florida State University.

Deetz, D.A., D.R. Buxton and H.G. Jung. 1996. Water-deficit effects on cell-wall composition and in vitro degradability of structural polysaccharides from alfalfa stems. Crop Sci. $36: 383-388$.

Demarty, M., C. Morvan and M. Thellier. 1984. Calcium and the cell wall. Plant, Cell and Envir. 7:441-448.

Demarty, M., C. Morvan and M. Thellier. 1978. Exchange properties of isolated cell walls of Lemna minor L. Plant Physiol. 62:477-481. 
DeWalle, D.R., G.C. Ribblett, J.D. Helvey and J. Kochenderfer. 1985. Laboratory investigation of leachate chemistry from six Appalachian forest floor types subjected to simulated acid rain. J. Environ. Qual. 14:234-240.

Eckert, D.J. 1987. Soil test interpretations: Basic cation saturation ratios and sufficiency levels. p. 53-64. In J.R. Brown (ed.) Soil Testing: Sampling, Correlation, Calibration and Interpretation. Spec. Publ. 21 ed. SSSA, Madison, WI.

Evangelou, V.P. 1995. Pyrite Oxidation and its Control. CRC/Lewis Press, Boca Raton, FL.

Fiez, T.E., B.C. Miller and W.L. Pan. 1994. Winter wheat yield and grain protein across varied landscape positions. Agron. J. 86:1026-1032.

Goff, J.P. 2000. Determining the mineral requirement of dairy cattle. p. 106-132. In Determining the mineral requirement of dairy cattle. Proc. 11th Annual Florida Ruminant Nutrition Symposium, University of Florida. 2000. Gainesville, FL.

Goulding, K.W.T, and B. Annis. 1998. Lime, liming and the management of soil acidity. p. 36. In Lime, liming and the management of soil acidity. Proc. Fertilizer Soc. No. 410, York.1998. The International Fertilizer Society, UK.

Graham, E.R. 1959. An explanation of theory and methods of soil testing. Rep. 734. Missouri Agric. Exp. Stn., Columbia, USA.

Grant, G.T., E.R. Morris, D.A. Rees, P.J.C. Smith and D. Thom. 1973. Biological interactions between polysaccharides and divalent cations: The egg-box model. FEBS Lett. 32:195198. 
Haby, V.A., M.P. Russelle and E.O. Skogley. 1990. Testing soils for potassium, Ca, and Mg. p. 181-227. In R.L. Westerman (ed.) Soil Testing and Plant Analysis. 3rd ed. SSSA. Book Ser. 3. SSSA, Madison, Wisconsin, USA.

Hall, M. 2004. Managing for quality forage. In K. Cassida (ed.) Proc. Ame. Forages and Grassl. Counc, Roanoke, Virginia. June 12-16 2004.

Hall, M.B., L.E. Chase, P.J. Van Soest and B.A. Lewis. 1997. A simple method for estimation of neutral detergent-soluble fibre. J. Sci. Food Agric. 74:441-449.

Hangarter, R. 2004. Mechanism of Plant Growth and Develpoment. [Online.] Available at. http://www.bio.indiana.edu/ hangarterlab/courses/index.html. (accessed 12 January, 2010).

Hardter, R., M. Rex and K. Orlovius. 2004. Effects of different Mg fertilizer sources on the magnesium availability in soils. Nutr. Cycl. Agroecosyst. 70:249-259.

Harris, P.J. 2005. Diversity in plant cell walls. p. 201-227. In R.J. Henry (ed.) Plant Diversity and Evolution: Genotypic and Phenotypic Variation in Higher Plants. CAB International Publishing, Wallingford, Oxon, UK.

Hatfield, R.D. 1989. Structural polysaccharides in forages and their degradability. Agron. J. 81:39-46.

Hatfield, R.D. and J. Ralph. 1999. Cell wall structural foundations: Molecular basis for improving forage digestibilities. Crop Sci. 39:27. 
Hatfield, R.D. and P.J. Weimer. 1995. Degradation characteristics of isolated and in situ cell wall lucerne pectic polysaccharides by mixed ruminal microbes. J. Sci. Food Agric. 69:185196.

Henning, P.H., H.H. Meissner and D.G. Steyn. 1993. Effect of synchronization of energy and nitrogen supply on ruminal characteristics and microbial growth. J. Anim. Sci. 71:25162528.

Henning, J.C., G. D. Lacefield, D. A. Phillips 1995. Interpreting Forage Quality [Online.] Available at. http://www.ca.uky.edu/agc/pubs/id/id101/id101.pdf.(accessed 12 January, 2010. Reports, Cooperative Extension Service, University of Kentucky.

Hintz, R.W 1995. Defining Forage Quality. [Online.] Available at http://ucanr.org/alf_symp/1995/95-97.pdf. (accessed January 12, 2010) Alfalfa Symposium, California

Iannucci, A., M. Russo, L. Arena, N. Di Fonzo and P. Martiniello. 2002. Water deficit effects on osmotic adjustment and solute accumulation in leaves of annual clovers. Eur. J. Agron. $16: 111$.

Iiyama, K., T. Lam and B.A. Stone. 1994. Covalent cross-links in the cell wall. Plant Physiol. 104:315-320.

Johnson, G.V. and H. Zhang. 2010. Cause and effects of soil acidity. [Online.] Available at http://pss.okstate.edu/publications/soilsandsoilfertility/PSS-2239.pdf.(accessed 16 Feb, 2010) Rep. Fact Sheet PSS-2239. Oklahoma Cooperative Extension Service. 
Jones, M.M., N.C.Turner and C.B. Osmond. 1981. Mechanisms of drought resistance. p. 20-35. In L.G. Paleg and D. Aspinall (eds.) The Physiology and Biochemistry of Drought Resistance in Plants. Academic Press, Sydney.

Jung, H.G. 1996. Breeding for improved forage quality in alfalfa: An animal nutritionist's view. p. 7. In Breeding for Improved Forage Quality in Alfalfa: An Animal Nutritionist's View. 35th North American Alfalfa Improvement Conf. June 16-19 1996. Oklahoma City, OK.

Jung, H.G. and M.S. Allen. 1995. Characteristics of plant cell walls affecting intake and digestibility of forages by ruminants. J. Anim. Sci. 73:2774-2790.

Kamprath, E.J. 1971. Potential detrimental effects from liming highly weathered soils to neutrality. Proc. Soil Crop Sci. Soc. Fla. 31:200-203.

Keltjens, W.G. and W.J. Dijkstra. 1991. The role of magnesium and calcium in alleviating aluminium toxicity in wheat plants. Dev. in Plant Soil Sci. 45:763-768.

Kramer, D., M. Desbiez, J.P. Garrec, M. Thellier, A. Fourcy and J.P. Bossy. 1980. The possible role of potassium in the activation of axillary buds of Bidens pilosus L. after decapitation of the apex: An Examination by X-Ray Microanalysis. J. Exp. Bot. 31:771-776.

Kugler, J.(ed.) 2004 Proc. National Alfalfa Symp., 13-15 Dec. 2004. [Online.] Available at http://grant-adams.wsu.edu/agriculture/forage/pubs/06-12 02producinghighqualityorchardgrassandtimothyhay.pdf. (accessed 16 Feb,2010) San Diego, CA. 
Lagowski, J.M., H.M. Sell, C.F. Huffman and C.W. Duncan. 1958. The carbohydrates in alfalfa Medicago sativa. I. General composition, identification of a nonreducing sugar and investigation of the pectic substances, Arch. Biochem. Biophys. 76:306-316.

Li, H., R.J. Lascano, J. Booker, L.T. Wilson and K.F. Bronson. 2001. Cotton lint yield variability in a heterogeneous soil at a landscape scale. Soil and Tillage Res. 58:245-258.

Liebhardt, W.C. 1981. The basic cation saturation ratio concept and lime and potassium recommendations on Delaware's coastal plain soils. Soil Sci. Soc. Am. J. 45:544-549.

Linn, J.G. and N. P. Martin. 1999. Forage quality test and interpretations. Rep. AG-FO-2637. Minnesota Extension Service, University of Minnesota, St. Paul.

Liu, H., D. Sun and R. Zhou. 2005. $\mathrm{Ca}^{2+}$ and AtCaM3 are involved in the expression of heat shock protein gene in Arabidopsis. Plant Cell Environ. 28:1276-1284.

Loew, O. and D.W. May. 1901. The relation of lime and magnesia to plant growth. Rep. Bull. 1. USDA Bur. of Plant Industries, Washington, DC.

Longhurst, J.W.S. 1991. Acid Deposition: Origin, impacts and abatement strategies. Springer Verlag, NY,USA.

Lozier, J., E. Rayburn and J. Shaw. 2004. Growing and selling pasture-finished beef: Results of a nationwide survey. J. Sustainable Agric. 25:93-112.

Lyngstad, I. 1992. Effect of liming on mineralization of soil nitrogen as measured by plant uptake and nitrogen released during incubation. Plant Soil 144:247-253.

Marschner, H. 1995. Mineral Nutrition of Higher Plants. Academic Press, London ; San Diego. 
McCormick, M.E., D.C. Blouin, J.D. Ward and D.D. Redfearn. 2001. Effect of protein source and soluble carbohydrate addition on rumen fermentation and lactation performance of Holstein cows. J. Dairy Sci. 84:1686-1697.

McLean, E.O. 1977. Contrasting concepts in soil test interpretation: Sufficiency levels of available nutrients versus basic cation saturation ratios. p. 39-54. In T.R. Peck (ed.) Correlating and Interpreting the Analytical Result. ASA Spec. Publ. 29 ed. ASA, CSSA, and SSSA, Madison, WI.

McLean, E.O. and M.D. Carbonell. 1972. Calcium, magnesium, and potassium saturation ratios in two soils and their effects upon yields and nutrient contents of German millet and alfalfa. Soil Sci. Soc. Am. J. 36:927-930.

Michaux, A. 1951. Structural materials of vegetable cellular membranes during digestion by the ewe. C. R. Acad. Sci 232:121-123.

Miron, J., D.E. Bauman, R. Solomon, L.E. Chase, E. Yosef and D. Ben-Ghedalia. 2002. Digestibility by dairy cows of monosaccharide constituents in total mixed rations containing citrus pulp. J. Dairy Sci. 85:89-94.

Misra, A. and G. Tyler. 2000. Effect of wet and dry cycles in calcareous soil on mineral nutrient uptake of two grasses, Agrostis stolonifera L. and Festuca ovina L. Plant Soil 224:297303.

Moore, K.J. and H.G. Jung. 2001. Lignin and fiber digestion. J. Range Manage. 54:420-430.

Moschler, W.W., D.C. Martens, C.I. Rich and G.M. Shear. 1973. Comparative lime effects on continuous no-tillage and conventionally tilled corn. Agron. J. 65:781-783. 
NASS. 2005. National Agricultural statistics service. . [Online.] Available at http://www.nass.usda.gov/. (Accessed 10 January 2010).

Nielsen, D.C. 2004. Kenaf forage yield and quality under varying water availability. Agron. J. 96:204-213.

Nielsen, D.C., J.G. Benjamin and M.F. Vigil. 2006. Forage yield response to water use for dryland corn, millet, and triticale in the central Great Plains. Agron. J. 98:992-998.

Nyborg, M. and P.B. Hoyt. 1978. Effects of soil acidity and liming on mineralization of soil nitrogen. Can. J. Soil Sci.331-338.

Nye, P.H. 1981. Changes of pH across the rhizosphere induced by roots. Plant Soil 61:7-26.

Olsen, S.R., W.D. Kemper and J.C. Van Schaik. 1965. Self-diffusion coefficients of phosphorus in soil measured by transient and steady-state methods. Soil Sci. Soc. Am. J. 29:154-158.

Osemwota, I.O., A.I. Ogboghodo and J.A.I. Omueti. 2007. Effect of Calcium/Magnesium ratio in soil on magnesium availability, yield, and yield components of maize. Commun. Soil Sci. Plant Anal. 38:2849-2860.

Patterson, G. (2010). Calcium nutrition in plants. [Online.] Available at http://www.calciumproducts.com/Calcium_Nutrition_in_plants.pdf. (accessed 16 Jan. 2010).

Pennock, D.J., B.J. Zebarth and E. De Jong. 1987. Landform classification and soil distribution in hummocky terrain, Saskatchewan, Canada. Geoderma 40:297-315.

Philipp, D., C.P. Brown, V.G. Allen and D.B. Wester. 2006. Influence of irrigation on mineral concentrations in three old world bluestem species. Crop Sci. 46:2033-2040. 
Piaggio, L. and E. R. Prates. 1997. Dry matter intake and liveweight gain related to sward characteristics and quality. In XVIII International Grassland Congress, Winnipeg, Manitoba Saskatoon, Saskatchewan, Canada. June 8-19 1997.

Pierce, J. 1986. Determinants of substrate specificity and the role of metal in the reactions of ribulosebisphosphate carboxylase/oxygenase. Plant Physiol. 81:943-945.

Queitsch, C., S. Hong, E. Vierling and S. Lindquist. 2000. Heat shock protein 101 plays a crucial role in thermotolerance in Arabidopsis. Plant Cell 12:479-492.

Ranieri, A., G.F. Soldatini, P. Lanese and R. Bernardi. 1989. Changes in free amino acid content and protein pattern of maize seedlings under water stress. Environ. Exp. Bot. 29:351-357.

Reichman, G.A., D.L. Grunes and F.G. Viets Jr. 1966. Effect of soil mositure on ammonification and nitrification in two northern plains soils. Soil Sci. Soc. Am. J. 30:363-366.

Ridley, B.L., D. Mohnen and M.A. O'Neill. 2001. Pectins: Structure, biosynthesis, and oligogalacturonide-related signaling. J. Phytochemistry 57:929-967.

Ritchey, K.D. and J.D. Snuffer. 2002. Limestone, gypsum, and magnesium oxide influence restoration of an abandoned Appalachian pasture. Agron. J. 94:830-839.

Robinson, J.B.D. 1957. The critical relationship between soil moisture content in the region of wilting point and mineralization of natural soil nitrogen. J. Agric. Sci. 49:100-105.

Rossignol, M., D. Lamant, L. Salsac and R. Heller. 1977. Calcium fixation by the roots of calcicole and calcifuge plants: The importance of membrane systems and their lipid composition. p. 483-490. In M. Thellier, A. Monnier, M. Demarty and J. Dainty (eds.) 
Transmembrane Ionic Exchange in Plants. Editions du CNRS ed. Paris et Editions de l'Universite, Rouen.

Saeed, I.A.M. and A. El-Nadi. 1998. Forage sorghum yield and water use efficiency under variable irrigation. Irrig. Sci. 18:67-71.

Schulte E.E. and K.A. Kelling. 1993. Soil calcium to magnesium ratios - should you be concerned? Rep. A2986. Cooperative Extension Publications, University of Wisconsin.

Schroeder, J.W 1994. Interpreting Forage Analysis. [Online.] Available at http://www.ag.ndsu.edu/pubs/plantsci/hay/r1080w.htm.(accessed 16 Jan. 2010) Pioneer Forage Manual AS 1080.

Seguin, P., A.F. Mustafa and C.C. Sheaffer. 2002. Effects of soil moisture deficit on forage quality, digestibility, and protein fractionation of kura clover. J. Agron. Crop Sci. 188:260-266.

Sentenac, H. and C. Grignon. 1981. A model for predicting ionic equilibrium concentrations in cell walls. Plant Physiol. 68:415-419.

Shaul, O. 2002. Magnesium transport and function in plants: The tip of the iceberg. Biometals 15:309-323.

Simon, E.W. 1978. The symptoms of calcium deficiency in plants. New Phytol. 80:1-15.

Smith, G.E. and W.A. Albrecht. 1942. Feed efficiency in terms of biological assays of soil treatments. Soil Sci. Soc. Am. Proc 7:322-330. 
Sniffen, C.J., D.G. Fox, J.B. Russell, J.D. O'Connor and P.J. Van Soest. 1992. A net carbohydrate and protein system for evaluating cattle diets. II. Carbohydrate and protein availability. J. Anim. Sci. 70:3562-3577.

Skousen, J. and L.M. McDonald. 2005. Liming principles and lime products. [Online.] Available at http://anr.ext.wvu.edu/r/download/44896. (accessed June 3 2010). Extension Service West Virginia University, WV

Tepfer, M. and J.E.P. Taylor. 1981. The interaction of divalent cations with pectic substances and their influence on acid induced cell wall loosening. Can. J. Bot. 59:1522-1525.

Thibault, J.F. and M. Rinaudo. 1985. Interactions of mono- and divalent counterions with alkaliand enzyme-deesterified pectins in salt-free solutions. Biopolymers 24:2131-2143.

Thom, D., G.T. Grant, E.R. Morris and D.A. Rees. 1982. Characterisation of cation binding and gelation of polyuronates by circular dichroism. Carbohydr. Res. 100:29-42.

Tilman, D., M.E. Dodd, J. Silvertown, P.R. Poulton, A.E. Johnston and M.J. Crawley. 1994. The Park Grass experiment: Insights from the most long-term ecological study. p. 287-303. In R.A. Leigh and A.E. Johnston (ed.) Long-term Experiments in Agricultural and Ecological Sciences. CAB International,Wallingford, UK.

Tisdale, S.L., W.L. Nelson, J.D Beaton and J.L. Havlin. 1993. Soil and fertilizer sulfur, calcium and magnesium. p. 266-302. In Soil Fertility and Fertilizers. 5th ed. Macmillan publishing company, New york.

Truog, E. 1948. Lime in relation to availability of plant nutrients. Soil Sci. 65:1-8. 
Ulrich, B. 1994. Nutrient and acid-base budget of central European forest ecosystems. p. 1-50. In D. L. Godbold and A. Hüttermann (eds.) Effects of Acid Rain on Forest Processes. Wiley Liss, New York.

Undersander, D. 2004. What is forage quality and is it worth making? Am. Forag. Grassl. Counc. Proc. 13:149-155.

Van Itallie. Th. B. 1948. Cation equilibria in plants in relation to the soil: II. Soil Sci. 65(5):393416.

Van Raij, B. and J.A. Quaggio. 1990. Extractable phosphorus availability indexes as affected by liming. Commun. Soil Sci. Plant Anal. 21:1267-1276.

Van Soest, P.J. 1994. Nutritional ecology of the ruminant. Cornell University Press, Ithaca, NY.

Van Soest, P.J. 1995. What constitutes alfalfa quality: New considerations. p. 1-15. In What Constitutes Alfalfa Quality: New considerations. 25th Natl. alfalfa symposium, Liverpool, NY. Feb 27-28 1995.

Van Soest, P.J., J.B. Robertson and B.A. Lewis. 1991. Methods for dietary fiber, neutral detergent fiber, and nonstarch polysaccharides in relation to animal nutrition. J. Dairy Sci. 74:3583-3597.

Viands, D.R. 1995. What breeding objectives really will improve forage quality of alfalfa? p. 2428. In What Breeding Objectives Really Will Improve Forage Quality of Alfalfa? 25th Natl. Alfalfa Symposium. Feb. 27-28 1995. Liverpool, NY. 
Volaire, F. and H. Thomas. 1995. Effects of drought on water relations, mineral uptake, watersoluble carbohydrate accumulation and survival of two contrasting populations of cocksfoot (Dactylis glomerata L.). Ann. Bot. 75:513-524.

Waite, R. and A.R.N. Gorrod. 1959. The comprehensive analysis of grasses. J. Sci. Food Agric. $10: 317-326$.

White, P.J. and M.R. Broadley. 2003. Calcium in plants. Ann. Bot. 92:487-511.

White, P. et al., (2009). Increasing dietary $\mathrm{K}, \mathrm{Mg}$ and Ca intake through plants. [Online.] Available at http://www.scitopics.com/Increasing_dietary_K_Mg_and_Ca_intake_through_plants.htm 1. (accessed Feb 12 2010).

Williams, R.J.P. 1976. Calcium chemistry and its relation to biological function. p. 1-17. In Calcium in Biological Systems. Cambridge Univ. Press, Cambridge.

Wuytack, R. and C. Gillet. 1978. Nature des liaisons de Pion calcium dans la paroi de Nitella flexilis. (In French with English abstract.) Canad. J. Bot. 56:1439-1443.

Zhang, H., O.M. Kachurina, M.E. Payton, J.L. Schroder and E.G. Krenzer. 2004. Yield and quality of winter wheat forage as affected by lime. [Online.] Available at http://www.plantmanagementnetwork.org/pub/fg/research/2004/lime/. (accessed March 2, 2010) at Forage and Grazinglands. 


\section{CHAPTER 3}

\section{Effect of Water Potential and Liming Agent Calcium/Magnesium Ratio of on Sudangrass and Red clover Forage Yield and Quality}

\subsection{Introduction}

Approximately 25\% of land on earth (Pearson and Ison, 1997) and 50\% of all agricultural land in USA is under pasture (Lubowski et al., 2002). In West Virginia, of the 1.4 million hectares of farm land, 0.21 million hectares is under pasture (National Agricultural Statistics Service, 2005). Pasture-raised beef and sheep production is a major agricultural activity in the mountainous terrain of West Virginia. Undulating topography and uneven rainfall distribution causes variability in soil water potential across a field affecting nutrient status and crop productivity.

Much of the soil in WV is acidic (Ritchey and Snuffer, 2002), low in native fertility, and found on steep slopes. Basic cations are removed at a faster rate than their liberation from nonexchangeable forms (De Walle et al., 1985). Under acidic conditions, the available pool of alkali (K) and alkaline earth cations $(\mathrm{Ca}$ and $\mathrm{Mg}$ ) is reduced and the pool of potentially toxic cations such as $\mathrm{Al}$ ions, $\mathrm{H}^{+}$ion or $\mathrm{Mn}^{2+}$ ion is significantly increased (Ulrich, 1994). The conditions for nitrogen fixation and phosphate availability also become less favorable (Truog, 1948). Soil acidity reduces the overall agronomic yield by decreasing the number of plant species in grasslands and also reduces the nutritional quality of forage (Goulding and Annis, 1998; Tilman et al., 1994). 
Liming is the most common practice to correct soil acidity. Liming improves soil $\mathrm{pH}$ and enhances the availability of alkali and alkaline earth cations. However continuous use of calcitic liming agents can induce magnesium deficiency in plants because of the tendency of calcium ions to compete with $\mathrm{Mg}$ ions. Animals grazed on such lands are susceptible to Mg deficiency disease, known as Grass Tetany or Grass Staggers. (Goff, 2010; Ammerman and Goodrich, 1983).

Thus soil acidity and low soil moisture are two important limitations affecting forage yield and quality in WV. Several studies have examined the response of grassland to liming and soil moisture conditions measured independently as forage yield or quality. Most of the work on forage yield response to soil fertility has focused on the relationships between soil nitrogen and forage crude protein; other effects such as pectin concentration response have not received as much attention. Nor has much work been done to study the effect of $\mathrm{Ca} / \mathrm{Mg}$ ratio of the liming agent or its interaction with water potential on dry matter yield, crude protein concentration, mineral concentration, and, fiber and pectin concentration of forage crops. The objective of this experiment was to determine the effect of molar combinations of $\mathrm{Ca}$ : $\mathrm{Mg}$ in liming agent and water potential on yield and forage quality of a sudangrass and red clover mixture. Forage quality parameters included mineral composition, crude protein percentage, fiber and pectin concentration.

\subsection{Materials and Methods}

\subsubsection{Soil Sampling and Characterization}

A bulk sample $(\sim 100 \mathrm{~kg})$ of the A-horizon $(0-15 \mathrm{~cm})$ was collected from a farm located in Preston county, WV and transported to the WVU greenhouse. The soil was air-dried, sieved 
through a $10 \mathrm{~mm}$ mesh to remove large clods, stones and plant debris and stored in plastic containers. Soil was mapped as Ernest (fine-loamy, mixed, superactive, mesic aquic Fragiudults). Soil was primarily formed from parent material of acid colluvium derived from sandstone and shale (Soil Survey Staff, 2010).

A representative soil sample was drawn from the composite sample, and sieved through a $2 \mathrm{~mm}$ sieve. Soil was analyzed in duplicate for all physical and chemical properties. Soil physical and chemical properties were determined using standard protocols. Soil $\mathrm{pH}$ was measured in a 1:2 soil to water ratio (Schofield and Taylor, 1955) using a combination $\mathrm{pH}$ electrode (MettlerToledo, Inc., Columbus, OH, USA). Soil particle size was determined by a modified pipette procedure (Indorante et al., 1990). Total carbon and total nitrogen were determined by dry combustion (LECO Truspec CHN, Leco Corp. St. Joseph, MI) (Nelson and Sommers, 1996). Mehlich 1 extraction was used for secondary nutrient ( $\mathrm{Ca}, \mathrm{Mg}, \mathrm{K}$ and $\mathrm{P}$ ) determination (NEC67); micronutrients were determined by DTPA extraction (Whitney, 1998). Effective CEC was determined by summation of exchangeable base cations ( $\mathrm{K}, \mathrm{Ca}, \mathrm{Mg}$ ) and acid cation (Al) by 0.1 $\mathrm{M} \mathrm{BaCl}_{2}$ extraction (Hendershot, 1986). Exchangeable acidity was determined by $1 \mathrm{M} \mathrm{KCl}$ extraction (Sims, 1996). All elemental concentrations were determined by ICP (Perkin Elmer, Optima, 2100 DV, Norwalk, CT).

\subsubsection{Lime Requirement and Incubation Experiment}

Soil lime requirement was determined by direct titration with $0.022 \mathrm{M} \mathrm{Ca}(\mathrm{OH})_{2}$ (Liu et al., 2004) to a target $\mathrm{pH}$ of 6.5 (WVU Soil Test Laboratory recommendation). Titration was performed in 1:1 (w:v) soil water ratio. Ten $\mathrm{g}$ of air dried, ground, sieved $(2 \mathrm{~mm})$ soil was mixed with $10 \mathrm{ml}$ water and titrated with $0.022 \mathrm{M} \mathrm{Ca}(\mathrm{OH})_{2}$. The sample was covered with Parafilm to 
minimize evaporation. A thin slit was cut to allow air exchange. The base was added in 1.0 and $0.2 \mathrm{ml}$ increments for the $1 \mathrm{st}$ and $2 \mathrm{nd}$ day and $0.1 \mathrm{ml}$ for the $3 \mathrm{rd}$ and 4 th days. Suspensions were stirred continuously during the day and allowed to stand overnight. Suspension $\mathrm{pH}$ was recorded after 30 min of addition of base and monitored until final $\mathrm{pH}$ was achieved at the end of the 5 th day. The soil was incubated for two more days at room temperature $\left(25 \pm 1^{\circ} \mathrm{C}\right)$ and $\mathrm{pH}$ was recorded every $24 \mathrm{hr}$ until the end of the 7 th day.

Soil $\mathrm{pH}$ as a function of $\mathrm{Ca}(\mathrm{OH})_{2}$ was plotted and data points were fit using linear regression. Lime requirement was estimated by calculating the corresponding amount of $\mathrm{Ca}(\mathrm{OH})_{2}$ required to reach the target $\mathrm{pH}(6.5)$ using the regression equation. Based on the estimated lime requirement to reach the final $\mathrm{pH}$ of 6.5 , soil was amended with $\mathrm{Ca}(\mathrm{OH})_{2}$ and $\mathrm{Mg}(\mathrm{OH})_{2}$ in nine different molar ratios $(\mathrm{Ca} / \mathrm{Mg})$ ranging between 0 to $100(0 / 100,25 / 75,50 / 50$, 60/40, 70/30, 75/25, 80/20, 90/10, 100/0).

Ten $\mathrm{kg}$ of soil was used for each treatment ratio combination. The calculated amount of $\mathrm{Ca}(\mathrm{OH})_{2}$ and $\mathrm{Mg}(\mathrm{OH})_{2}$ were added to the soil and mixed thoroughly. Water was added approximately to field capacity and mixed. Soil was allowed to air dry on a plastic sheet for one week and mixed again in the same fashion. This was repeated two more times to ensure proper mixing of the lime. Soils were then placed in bottom drained plastic pots $\left(1 \mathrm{~kg} \mathrm{pot}^{-1}\right)$ lined with coffee filter paper to prevent soil loss. Each pot $(15.2 \mathrm{~cm}$ x $10.8 \mathrm{~cm}$ x $10.2 \mathrm{~cm})$ was then placed in a clear plastic saucer $(15.2 \mathrm{~cm} \times 15.2 \mathrm{~cm}$ x $5.1 \mathrm{~cm})$ containing water. Once water reached the surface, the plastic saucer was removed and pots were drained from top. This leaching cycle was repeated two more times. The capillary action of water allowed uniform mixing, provided enough reaction time and washed away excess salt from all the pots. Soils from same treatment 
pots were then bulked together, mixed, and air dried before adding to the final experimental unit pots.

\subsubsection{Water Potential Treatments and the Experimental Setup}

The experiment was a $9 \times 2$ factorial in a completely randomized design with five replications. The treatments consisted of nine levels of $\mathrm{Ca} / \mathrm{Mg}$ ratio of liming agent $\left(\right.$ as $\mathrm{Ca}(\mathrm{OH})_{2}$ and $\left.\mathrm{Mg}(\mathrm{OH})_{2}\right)$ and two water levels. Water treatments were low water potential (frequently irrigated) and high water potential (poorly irrigated).

One kilograms of weighed air dry soil was placed in pots and randomly assigned to water potential and positions on the greenhouse bench. Soil moisture content was controlled using a sensor-based irrigation system (Acclima SC6/12 closed loop irrigation systems, Acclima Inc.). Volumetric moisture content was set at $10 \pm 2 \%$ (poorly irrigated) and $40 \pm 5 \%$ (frequently irrigated). The dripper was inserted at the center of the pot and water volume delivered was measured periodically to ensure proper functioning of the irrigation system. Water potential was measured on randomly selected pots every week with a Dew Point potentiometer (WP4-T, Decagon Devices, Pullman, WA). Pots were seeded with sudangrass (Sorghum X drummondii) and red clover (Trifolium pretense) each at a rate of $4 \mathrm{gm} \mathrm{pot}^{-1}$ on $18^{\text {th }}$ June 2008 . Red clover was inoculated with Rhizobium trifoli by spraying, prior to seeding. Pots were misted to facilitate germination using an automatic electronic leaf system (Electronic Leaf, Phytotronics. Co.). After emergence, the misting system was replaced with the Acclima irrigation system for controlling water potential. Weeds were removed periodically and daily max/min temperature was recorded for the entire growing period with a temperature data logger (Watch Dog 2000, Spectrum Technologies, Inc., USA). 
Sudangrass and red clover were harvested separately by clipping at $9 \mathrm{~cm}$ and $2 \mathrm{~cm}$ respectively above the soil surface. Sudangrass was harvested 77 days after sowing in late boot stage (R0) to inflorescence emergence stage (R1) (Moore et al. 1991). Red clover was harvested 185 days after sowing in late vegetative to early bloom stage. The reason for the late clover harvest was suppression by sudangrass. In anticipation of sudangrass re-growth after its $1^{\text {st }}$ harvest, pots were fertilized with ammonium nitrate at a rate of $67 \mathrm{~kg} / \mathrm{ha}$ in two split doses at an interval of 35 days. Sudangrass failed to emerge after the $1^{\text {st }}$ cut due to suppression by red clover.

Following harvest, sudangrass was separated into three parts-young leaf blade, old leaf blade, and stem; red clover was not separated. Fresh weight was recorded to the nearest $0.01 \mathrm{~g}$. All parts except stem portion (sudangrass), were dipped in liquid nitrogen (-196 degree Celsius) to arrest physiological processes, stop enzymatic reactions and stabilize the sample. Samples were then freeze dried (Virtis Freezemobile 12SL, Vertis Gardiner Inc., NY, USA) for 48 hours. Sudangrass stems were oven-dried for $72 \mathrm{hr}$ at 50 degree Celsius. After drying, samples were ground to pass a $1 \mathrm{~mm}$ screen using a Wiley mill (Thomas-Wiley Model 4, Arthur M. Thomas Co.) and preserved in airtight polypropylene containers.

\subsubsection{Forage Determinations}

Herbage accumulation was measured as drymatter. (AOAC, 922.02, 1990). Crude protein was determined as a percentage of total $\mathrm{N}$ multiplied by 6.25 . Total $\mathrm{N} \%$ was determined by dry combustion (AOAC, 990.03, 1990) using LECO Truspec CHN. Plant minerals (Ca, Mg, P and K) were determined by nitric acid digestion using microwave (MARS 5, CEM Corp., Matthews, NC, USA) followed by ICP-OES (Perkin Elmer 2100 DV, Norwalk, CT) analysis of the extract (Havlin and Solltanpour, 1980). Nutrient concentrations were expressed on a tissue dry mass 
percentage basis. Pectin was determined according to the method outlined by Stern and Endres (1991) with a few modifications in reagent concentration (Appendix 4). neutral detergent fiber (NDF), acid detergent fiber (ADF) and acid detergent lignin (ADL) in forage samples were determined with an ANKOM A200 Filter Bag Technique (FBT) as outlined in ANKOM application note 05/03 (Appendix 5).

\subsubsection{Statistical Analysis}

Data for forage yield and quality parameters were analyzed as a $9 \times 2$ factorial experiment in a completely randomized deign with five replications. All the data were analyzed using the general linear model procedure in the statistical package SAS (Ver 9.1, SAS Institute, Inc., Cary, NC, USA). The alpha value was set at 0.05 for all analysis. Data were checked for normality and homoscedacity assumptions. Treatment means were compared by using Fisher's LSD $(\mathrm{P}=0.05)$ when the main effect was found significant. Unless stated, data are presented as LSmeans. Best fit polynomial was used to show relationships among the parameters.

\subsection{Results and Discussion}

The initial $\mathrm{pH}$ of the soil as collected was 5.7. Clay content was 37\%; silt content was $40 \%$. Exchangeable acidity was $3.8 \mathrm{cmol}_{\mathrm{c}} \mathrm{kg}^{-1}$ soil, and exchangeable $\mathrm{H}^{+}$was $3.5 \mathrm{cmol}_{\mathrm{c}} \mathrm{kg}^{-1}$ soil. Soil had an initial concentration of Mg: $98 \mathrm{mg} \mathrm{kg}^{-1}$, Ca: $1265 \mathrm{mg} \mathrm{kg}^{-1}, \mathrm{~K}: 116 \mathrm{mg} \mathrm{kg}^{-1}$ and P: 39 $\mathrm{mg} \mathrm{kg}^{-1}$.The relative availability or sufficiency levels of all these macronutrients fall under: $\mathrm{Mg}$ (medium), Ca (medium high) $\mathrm{K}$ (high) and $\mathrm{P}$ (high) (As per the fertlilizer recommendations of soil test lab by West Virginia University). The CEC of soil was $8 \mathrm{cmol}_{\mathrm{c}} \mathrm{kg}^{-1}$. The acidity saturation \% (H+Al) was $48 \%$ (Table 3.1). All high water potential (poorly irrigated) had on an average, a $\mathrm{kPa}$ of -2463 and low water potential (frequently irrigated) had $\mathrm{kPa}$ of -16 . This 
corresponded to a $10 \%$ and $40 \%$, volumetric water respectively (Appendix A1.1). The lime requirement of the soil was $0.89 \mathrm{Mg} \mathrm{CaCO}_{3} \mathrm{ha}^{-1}$. Molar ratios of $\mathrm{Ca}$ and $\mathrm{Mg}$ were calculated based on this value (Appendix 2). Addition of the molar combination of $\mathrm{Ca}(\mathrm{OH})_{2}$ and $\mathrm{Mg}(\mathrm{OH})_{2}$ followed by mixing increased the $\mathrm{pH}$ of the soil across all the nine treatment combinations. The average $\mathrm{pH}$ was $6.4 \pm 0.02$. The resulting $\mathrm{Ca}: \mathrm{Mg}$ ratio obtained from soil the Mehlich1 test ranged from $4: 1$ to $17: 1$.

\subsubsection{Crop Yield}

There were significant main effects of water potential and $\mathrm{Ca} / \mathrm{Mg}$ ratio on drymatter yield of sudangrass, with interaction between water potential and $\mathrm{Ca} / \mathrm{Mg}$ ratio (Table 3.3). Fisher's LSD test on means for main effects of water potential and $\mathrm{Ca} / \mathrm{Mg}$ ratio indicated a least significant difference of 1.3 and $2.8 \mathrm{~g} \mathrm{pot}^{-1}$ respectively (Table 3.6a Table 3.6b). Sudangrass maintained under high irrigation condition (frequently irrigated) produced higher drymatter yield (Table 3.6.a). Comparison between means for drymatter indicated a higher drymatter yield for 4:1 Ca/Mg ratio than $17: 1$ (Table 3.6b). With an increase in $\mathrm{Ca} / \mathrm{Mg}$ ratio from $4: 1$ to $8: 1$, drymatter first decreased from $23.88 \mathrm{~g} \mathrm{pot}^{-1}$ to $19.76 \mathrm{~g} \mathrm{pot}^{-1}$ and then increased to $25.15 \mathrm{~g} \mathrm{pot}^{-1}$ (at a ratio of 12:1). This finding agrees with the report of Osemwota et al., (2007) in which they found a similar pattern in maize yield response to soil $\mathrm{Ca} / \mathrm{Mg}$ ratio. They found the highest drymatter yield at an applied soil $\mathrm{Ca} / \mathrm{Mg}$ ratio of $8: 1$.

The $\mathrm{Ca} / \mathrm{Mg}$ ratio of agronomic interest is from 7:1 to $17: 1$ corresponding to pure dolomite $(50-50 \mathrm{Ca} / \mathrm{Mg})$ to pure calcite $(100 \% \mathrm{Ca})$. Within this range the highest drymatter was produced at $\mathrm{Ca} / \mathrm{Mg}$ ratio of $12: 1$. The effect of one cation is masked by the abundance of other cation. 
However they produce a synergistic effect when present in a favorable range (12:1 for sudangrass).

In red clover, there was a significant main effect of water potential (Table 3.3 ) but not of the $\mathrm{Ca} / \mathrm{Mg}$ ratio. Frequently irrigated pots produced more drymatter compared to poorly irrigated $(\mathrm{LSD}=0.60)$ (Table 3.7). This response to $\mathrm{Ca}: \mathrm{Mg}$ ratio agrees with the findings of Hunter (1949), who did not find any significant response of $\mathrm{Ca} / \mathrm{Mg}$ ratio on alfalfa. Herbage response to calcium /magnesium also varies widely between plant species and genotypes. Several researchers have found that the effect of soil $\mathrm{Ca} / \mathrm{Mg}$ ratio on yield varies from non significant response to small differences in response (Hunter et al., 1943; Sanik 1952).

Water potential had a significant effect on drymatter because of the mass flow effect. Mass flow is the mechanism for $\mathrm{Ca}$ and $\mathrm{Mg}$ uptake in plants rather than root interception. In well irrigated condition, the magnitude of mass flow and diffusion increases (Mackay and Barber, 1985). Compared to low irrigated condition, a higher dry matter response to increased irrigation was also found by Nielsen (2004) in Kenaf (Hibiscus cannabinus L.). According to this model, the dry matter of Kenaf increased by $17.1 \mathrm{~kg} / \mathrm{ha}$ for every mm of water use after an initial use of 157 mm water. If a third water potential level (intermediate between the two levels used) would have been included in the present study, it would have given a better picture of the trend in the relationship between dry matter production of water potential.

\subsubsection{Crude Protein}

The main effects of $\mathrm{Ca} / \mathrm{Mg}$ ratio and water potential on crude protein concentration were significant both in the young and old leaf blades, with no interaction (Table 3.4). Crude protein percentage was higher in dry condition (poorly irrigated) than in well irrigated condition 
(frequently irrigated) (Table3.6a). Highest $\mathrm{CP}$ percentage was observed at a $\mathrm{Ca} / \mathrm{Mg}$ ratio of 7:1 in young leaf blade and 4:1 in old leaf blade (Table 3.6b).

Red clover responded in a similar fashion as the sudangrass except that the interaction was significant (Table 3.4, Figure 3.1). Under poorly irrigated condition, the crude protein percentage increased with increase in $\mathrm{Ca} / \mathrm{Mg}$ ratio (Table 3.7). One reason for increase in crude protein might be because of the effect of $\mathrm{NH}_{4} \mathrm{NO}_{3}$ fertilization that was applied after the harvest of sudangrass in anticipation for its regrowth.

Several researchers reported that crude protein response to soil moisture conditions was inconsistent. Seguin (2002) found no effect of soil moisture deficit on crude protein concentration of Kura clover. However, many other researchers have reported that CP concentration increase in moisture deficit conditions. Nielsen (2004) reported a decline in crude protein content of Kenaf forage under high irrigation condition ( $450 \mathrm{~mm}$ water use). Seguin (2002) did not find any difference in CP concentration probably because Kura clover is often reported to be highly drought tolerant (Watson et al., 1998) and hence the CP response was masked under moisture deficit condition.

Crude protein response to soil moisture regime seems to depend on the severity of moisture deficit and on the plant's ability to tolerate moisture stress by synthesizing more proteins. Lary (1984) reported that crude protein concentration of legumes was almost double than grasses which is consistent with our findings.

\subsubsection{Mineral Concentration}

In the young sudangrass leaf blade, the main effect of $\mathrm{Ca} / \mathrm{Mg}$ ratio was significant only for $\mathrm{Ca}, \mathrm{Mg}$ and $\mathrm{K}$ (Table 3.5). The main effect of water potential was significant only for $\mathrm{Ca}$ and 
$\mathrm{Mg}$ (Table 3.5). Interaction effect was significant only for Ca (Figure 3.2). Calcium

concentration in young leaf blade increased with increasing soil $\mathrm{Ca} / \mathrm{Mg}$ ratio (Figure 3.2). The highest $\mathrm{Ca}$ concentration $(0.35 \%)$ was found at a ratio of 11:1. The $\mathrm{Mg}$ concentration decreased with increasing $\mathrm{Ca}$ : $\mathrm{Mg}$ ratio (Figure 3.2). However an increase in $\mathrm{Mg}$ concentration was observed at 11:1 $\mathrm{Ca} / \mathrm{Mg}$ ratio. $\mathrm{K}$ showed no trend except that $\mathrm{K}$ concentration was higher in poorly irrigated condition and at a $\mathrm{Ca} / \mathrm{Mg}$ ratio of 17:1(Table 3.6a, Table 3.6b).

In the sudangrass old leaf blade, all the four mineral elements ( $\mathrm{Ca}, \mathrm{Mg}, \mathrm{P}$, and $\mathrm{K}$ ) were significant for the main effect of $\mathrm{Ca} / \mathrm{Mg}$ ratio and water potential (Table 3.5). There were no significant interaction for any of the mineral elements Calcium concentration declined until a ratio of 7:1 and thereafter it increased again (Table 3.6b). On the other hand, Mg concentration showed a declining trend with increasing $\mathrm{Ca} / \mathrm{Mg}$ ratio. Potassium concentration was higher in poorly irrigated condition as in young leaf blade of sudangrass. It first declined with increasing $\mathrm{Ca} / \mathrm{Mg}$ ratio and then increased again (Table 3.6b).

In red clover there was a main effect of $\mathrm{Ca} / \mathrm{Mg}$ ratio and water potential with no significant interaction on all the four tissue mineral concentration (Table 3.5). Calcium concentration in the tissue first declined and then increased with increasing $\mathrm{Ca} / \mathrm{Mg}$ ratio (Figure 3.3). The highest $\mathrm{Ca}(2.7 \%)$ was obtained at a $\mathrm{Ca} / \mathrm{Mg}$ ratio of $11: 1$. (Table.3.7). Contrary to this, $\mathrm{Mg}$ followed a reverse trend. The highest $\mathrm{Mg}$ concentration (1\%) was found at a $\mathrm{Ca} / \mathrm{Mg}$ ratio of 6:1 and decreased with increasing $\mathrm{Ca} / \mathrm{Mg}$ ratio. Calcium and $\mathrm{Mg}$ concentration were higher in frequently irrigated condition than poorly irrigated condition (Table 3.7). However K concentration was higher in poorly irrigated condition. Calcium/Magnesium ratio in soil was also found to be positively and significantly correlated $(\mathrm{P}<0.05)$ with tissue Ca concentration and 
negatively and significantly correlated $(\mathrm{P}<0.05)$ with tissue $\mathrm{Mg}$ concentration in both the species. With increasing $\mathrm{Ca} / \mathrm{Mg}$ ratio in soil, plant $\mathrm{Mg}$ concentration decreased while $\mathrm{Ca}$ concentration increased in both sudangrass and red clover. This finding is consistent with the work of Wheeler and Edmeades (1995) and Osemwota (2007) where they found that with an increase in Ca concentration in culture media, plant $\mathrm{Mg}$ uptake decreased. Wheeler and Edmeades (1995) also suggested that Ca competes with $\mathrm{Mg}$ when $\mathrm{Mg}$ is transported from the roots; a "competitive ion effect" (Wheeler and Edmeades 1995). They also reported an "ameliorative effect" of adding $\mathrm{Ca}$ and $\mathrm{Mg}$ ion when $\mathrm{Al}$ is present in the culture media. Yield tends to increase even when $\mathrm{Al}$ is present in the culture media (Wheeler and Edmeades, 1995).

The uptake of $\mathrm{Ca}, \mathrm{Mg}$ and $\mathrm{K}$ by roots and their translocation to shoots were affected by $\mathrm{Ca}: \mathrm{Mg}$ ratio and water potential. In poorly irrigated condition, the increased concentration of $\mathrm{K}$ may be the result of increased net translocation of $\mathrm{K}$ from roots to shoots, rather than increased absorption of $\mathrm{K}$ by roots since its concentration in the soil was limiting. Although the $\mathrm{Ca} / \mathrm{Mg}$ ratio significantly affected phosphorous concentration in plant tissue but no pattern is evident nor it be explained.

\subsubsection{Pectin concentration}

Pectin concentration ( Galacturonic concentration) in both parts of sudangrass (young and old leaf blade) was significantly affected by $\mathrm{Ca} / \mathrm{Mg}$ ratio but not by water potential (Table 3.9). There was a significant interaction for both the factors (Figure 3.4). Higher $\mathrm{Ca}$ : $\mathrm{Mg}$ ratio favored pectin synthesis. A comparison of $\mathrm{LS}$ means for $\mathrm{Ca} / \mathrm{Mg}$ ratio 17:1 and 4:1 indicated higher pectin concentration for17:1 in well irrigated condition. In poorly irrigated condition both ratios had similar effect on pectin concentration. 
In sudangrass young leaf blade, the highest pectin concentration (2.7\%) was found under frequently irrigated condition (17:1 $\mathrm{Ca} / \mathrm{Mg}$ ratio), while in poorly irrigated condition $\mathrm{Ca} / \mathrm{Mg}$ ratio of 10:1 had the highest concentration (2.5\%) (Figure 3.4). A similar response was observed in old leaf blade as well (Figure 3.5). The pectin concentration in poorly irrigated condition for $\mathrm{Ca} / \mathrm{Mg}$ ratio 10:1 was not significantly different than frequently irrigated condition for $\mathrm{Ca} / \mathrm{Mg}$ ratio of 17:1.

In the sudangrass young leaf blade, a positive correlation was found between the soil $\mathrm{Ca} / \mathrm{Mg}$ ratio and tissue $\mathrm{Ca} / \mathrm{Mg}$ ratio $(\mathrm{P}<0.001, \mathrm{r}=0.76)$ and with pectin concentration $(\mathrm{P}<$ $0.001, r=0.64)$. There was no significant correlation between water potential and pectin concentration $(\mathrm{P}=0.8543)$.

In the sudangrass old leaf blade, the pectin concentration was positively and very weakly correlated with soil $\mathrm{Ca} / \mathrm{Mg}$ ratio $(\mathrm{P}<0.001, \mathrm{r}=0.28)$ and tissue $\mathrm{Ca} / \mathrm{Mg}$ ratio $(\mathrm{P}<0.001, \mathrm{r}=0.23)$. Growing tissues such as the young leaf blade have maximum demand for $\mathrm{Ca}$ and acts as sink because of formation of new binding sites (Kirkby and Pilbeam, 1984).These significant correlations among soil $\mathrm{Ca} / \mathrm{Mg}$, tissue $\mathrm{Ca} / \mathrm{Mg}$ and pectin concentration (though not strong) is indicative of the probability of elongation of uronic acid chains through $\mathrm{Ca}$ and $\mathrm{Mg}$ cross linkages and hence an increase in pectin concentration.

In poorly irrigated condition, it appears that the pectin synthesis is governed by other factors besides Ca:Mg ratio alone. Maas (1969) reported that uptake of $\mathrm{Ca}$ is chiefly concentration dependent and $\mathrm{Ca}$ moves into the root by diffusion at higher soil $\mathrm{Ca}$ concentration whereas in low Ca concentration uptake is metabolically controlled. Several researchers have reported that environmental signals such as drought induced abscisic acid (ABA), auxin (IAA), 
pathogenic infection or mechanical stress activate calcium channels in membranes and increase calcium influx. (Tester, 1990; Felle, 1988; Atkinson et al., 1990; Rincon and Hanson, 1986). Another possible reason for this response might be because of increased evapotranspiration (ET) demand during summer season. Calcium movement takes place mainly through xylem (apoplastic pathway) and is passive in nature (Armstrong and Kirkby, 1976b). Because of higher ET demand, the influx of $\mathrm{Ca}$ and $\mathrm{Mg}$ could have increased and thus pectin synthesis was similar irrespective of water supply conditions.

Pectin concentration in red clover was significantly affected by $\mathrm{Ca} / \mathrm{Mg}$ ratio as well water potential (Table 3.9). However the interaction between these two factors was also found significant. It appeared from the data that the interaction was significant mainly due to difference in magnitude of response and not a synergism or interference response. Pectin concentration was higher in the frequently irrigated condition $(3.5 \%)$ than in the poorly irrigated condition $(2.1 \%)$ (Figure 3.6). Among all nine levels of $\mathrm{Ca} / \mathrm{Mg}$ ratio, the highest pectin was found at a $\mathrm{Ca} / \mathrm{Mg}$ ratio of 11:1 while the lowest was produced at 4:1. Within the agronomic region, pectin concentration first increased with increasing $\mathrm{Ca} / \mathrm{Mg}$ ratio, reached the highest at 11:1 and then declined (Figure 3.6). It can also be inferred that since the lowest pectin concentration was at a $\mathrm{Ca} / \mathrm{Mg}$ ratio of 4:1, Mg is not the primary cation in cross linking uronic acid molecules. It appears that $\mathrm{Ca}$ and $\mathrm{Mg}$ interact synergistically within a narrow range of $\mathrm{Ca} / \mathrm{Mg}$ ratio and favors the interchain association of uronic acid leading to higher pectin synthesis. The applied soil $\mathrm{Ca} / \mathrm{Mg}$ ratio was also weakly correlated with tissue $\mathrm{Ca} / \mathrm{Mg}$ ratio in red clover $(\mathrm{P}<0.0001, \mathrm{r}=$ $0.62)$ and pectin concentration $(\mathrm{P}<0.001, \mathrm{r}=0.34)$. Tissue $\mathrm{Ca} / \mathrm{Mg}$ ratio and pectin concentration were weakly correlated $(\mathrm{P}<0.001, \mathrm{r}=0.49)$ in red clover is further implicative of the probability of $\mathrm{Ca}$ and $\mathrm{Mg}$ cross linkage formation between uronic acid chains and thus greater synthesis of 
pectin molecules. Pectin concentration was also negatively and significantly correlated to soil water potential $(\mathrm{P}<0.0001, \mathrm{r}=-0.40)$.

In red clover, the pectin concentration was as high as $6.43 \%$ where as in sudangrass, it was $2.70 \%$. Many researchers have reported a higher Ca demand for legumes than grasses (Loneragan and Snowball, 1969) and this might be the reason for higher pectin concentration in red clover than sudangrass.

\subsubsection{Fibers}

In the young leaf blade of sudangrass, only NDF and ADF fractions were significantly affected by both $\mathrm{Ca} / \mathrm{Mg}$ ratio and water potential treatment (Table 3.10). Acid detergent lignin concentration was not significant (Table 3.10). Also, no significant interaction was found between these two factors on either of the two fiber fractions. Both NDF as well ADF fractions were higher in frequently irrigated condition than in poorly irrigated condition (Table 3.10a). The fiber concentrations (NDF, ADF) were respectively about $3.3 \%$ and $6.3 \%$ lower for poorly irrigated condition than well irrigation condition. In the old leaf blade (sudangrass), there was no significant effect of $\mathrm{Ca} / \mathrm{Mg}$ ratio on $\mathrm{NDF}$ and $\mathrm{ADF}$ fractions. However there was a significant main effect on ADL (Table 3.10).Water potential had significant effect only on NDF and ADF fractions. The interaction was not significant for all the three fractions (Table3.10). Frequently irrigated condition significantly increased the NDF and ADF fraction by $6.7 \%$ and $5.9 \%$ respectively. Within the agronomic region, the lowest $\mathrm{ADL}$ was produced at $\mathrm{Ca} / \mathrm{Mg}$ ratio of 11:1. However the value was statistically the same as for the $\mathrm{Ca} / \mathrm{Mg}$ ratio of $17: 1$.

In red clover, NDF was significantly affected by water potential but not by $\mathrm{Ca} / \mathrm{Mg}$ ratio (Table 3.10). The ADF and ADL fractions were significantly affected by both $\mathrm{Ca} / \mathrm{Mg}$ ratio and 
water potential (Table 3.10). The Interaction was not significant for all the three fractions. An increase in water availability from poorly irrigated condition to frequently irrigated condition increased the NDF fraction by $14.4 \%$, ADF fraction by $14.3 \%$ and ADL fraction by $11.2 \%$. Within the agronomic region of interest, all the levels of $\mathrm{Ca} / \mathrm{Mg}$ ratio had nearly the same effect on $\mathrm{ADF}$ fraction, however $\mathrm{ADL}$ fraction was lowest at $\mathrm{Ca} / \mathrm{Mg}$ ratio of 11:1.

Several researchers have found the concentration of fiber components (NDF, ADF, ADL) differ among plant species (Trlica, 1999; Tedeschi et al., 2001) as well with soil water availability (Seguin et al., 2002; Tran et al., 2009). A higher fiber response (NDF, ADF) in frequently irrigated condition was also observed by Tran et al., (2009) in temperate grasses. Increased water supply increases the growth rate and reduces the vegetative stage resulting in higher fiber concentration. High temperature during summer could be another factor which increased the fiber concentration. Higher temperatures usually increase metabolic activity and promote the fiber growth (Coleman and Henry, 2002). Also, higher fiber concentration helps plants to resist wilting associated with high temperature. At the same time, other cell wall components have to be compromised since higher fiber leads to dilution of cell wall components (Poppi et al., 1999).This also suggests why pectin concentration of red clover was higher than sudangrass.

\subsection{Conclusion}

Under greenhouse conditions, it can be concluded that water potential and $\mathrm{Ca} / \mathrm{Mg}$ ratio in liming agents and hence soil, have some significant effects on dry matter yield, crude protein concentration and uptake of $\mathrm{Ca}, \mathrm{Mg}, \mathrm{P}$ and $\mathrm{K}$ in both sudangrass and red clover. Within the region of agronomic interest, soil $\mathrm{Ca} / \mathrm{Mg}$ between $11: 1$ to $12: 1$, which was obtained from 
application of 75-25 (\%) and 80-20 (\%) $\mathrm{Ca}(\mathrm{OH})_{2}-\mathrm{Mg}(\mathrm{OH})_{2}$ respectively, was found to be optimal. Also this optimal ratio occurred in the 'High' sufficiency levels for $\mathrm{Ca}$ and $\mathrm{Mg}$ (As per the fertilizer recommendations of soil test lab by West Virginia University).It seems that within the sufficiency range, there exists a critical point at which the forage quality parameters start changing. This critical point exists within a narrow range above which forage quality parameters start to decline and below which the optimal has not been attained.

Pectin and fiber components in both the species were significantly affected by $\mathrm{Ca} / \mathrm{Mg}$ ratio. Frequently irrigated condition increased fiber components as compared to poorly irrigated condition. Pectin concentration was markedly influenced by $\mathrm{Ca} / \mathrm{Mg}$ ratio- a significant finding of our study. $\mathrm{A} \mathrm{Ca} / \mathrm{Mg}$ ratio of 11:1 appears to be the ratio of choice for liming recommendation since ADL was lowest and pectin content was higher. There seems to be merit in exploring more responses at this ratio. Based on the magnitude of differences for pectin, NDF, ADF and ADL, we conclude that $\mathrm{Ca} / \mathrm{Mg}$ ratio as well soil moisture conditions must be given consideration for soils that require liming for $\mathrm{pH}$ correction. More investigation is needed to find the critical point within the sufficiency range of nutrients. Multiple regressions can be used to construct the model but it will require more data points for precision of the model. Model development and prediction may be taken over for further investigation. 


\section{References}

Ammerman, C.B. and R.D. Goodrich. 1983. Advances in mineral nutrition in ruminants. J. Anim. Sci. 57:519-533.

AOAC. 1990. Official Methods of Analysis. Association of the Official Analytical Chemists, Arlington.

Armstrong, M.J. and E.A. Kirkby. 1979. Estimation of potassium recirculation in tomato plants by comparison of the rates of potassium and calcium accumulation in the tops with their fluxes in the xylem stream. Plant Physiol. 60:1143-1148.

Atkinson, M.M., L.D. Keppler, E.W. Orlandi, C.J. Baker and C.F. Mischke. 1990. Involvement of plasma membrane calcium influx in bacterial induction of the $\mathrm{K}+\mathrm{H}+$ and hypersensitive responses in tobacco. Plant Physiol. 92:215-221.

Coleman, S.W. and D. A. Henry. 2002. Nutritive value of herbage. p. 1-26. In M. Freer and H. Dove (eds.) Sheep Nutrition. CAB International, Wallingford, UK.

DeWalle, D.R., G.C. Ribblett, J.D. Helvey and J. Kochenderfer. 1985. Laboratory investigation of leachate chemistry from six Appalachian forest floor types subjected to simulated acid rain. J. Environ. Qual. 14:234-240.

Dunn, L.E. 1943. Lime requirement determination of soils by means of titration curves. Soil Sci. $56: 341-351$.

Felle, H. 1988. Cytoplasmic free calcium in Riccia fluitans L. and Zea mays L.: Interaction of $\mathrm{Ca}^{2+}$ and pH? Planta. 176:248-255. 
Filisetti-Cozzi, T.M.C.C. and N.C. Carpita. 1991. Measurement of uronic acids without interference from neutral sugars. Anal. Biochem. 197:157-162.

Goff, J.P. 2000. Determining the mineral requirement of dairy cattle. p. 106-132. In Determining the Mineral Requirement of Dairy Cattle. Proc. 11th Annual Florida Ruminant Nutrition Symposium, University of Florida, Gainesville, FL. 2000.

Goulding, K.W.T, and B. Annis. 1998. Lime, liming and the management of soil acidity. p. 36. In Lime, Liming and the Management of Soil Acidity. Proc. Fertilizer Soc. No. 410, York, UK. 1998. The International Fertilizer Society.

Hatfield, R.D. and J. Ralph. 1999. Cell wall structural foundations: Molecular basis for improving forage digestibilities. Crop Sci. 39:27.

Havlin, J.L. and P.N. Soltanpour. 1980. A nitric acid plant tissue digest method for use with inductively coupled plasma spectrometry. Commun. Soil Sci. Plant Anal. 11:969-980.

Hendershot, W.H. and M. Duquette. 1986. A simple barium chloride method for determining cation exchange capacity and exchangeable cations. Soil Sci. Soc. Am. J. 50:605-608.

Hunter, A.S., S. J. Toth and F.E. Bear. 1943. Calcium-potassium ratios for alfalfa. Soil Sci. $56: 61-72$.

Indorante, S.J., R.D. Hammer, P.G. Koenig and L.R. Follmer. 1990. Particle-size analysis by a modified pipette procedure. Soil Sci. Soc. Am. J. 54:560-563.

Islam, M.A., P.J. Milham, P.M. Dowling, B.C. Jacobs and D.L. Garden. 2004. Improved procedures for adjusting soil $\mathrm{pH}$ for pot experiments. Comm. Soil Sci. Plant Anal. 35:2537. 
Kirkby, E.A. and D.J. Pilbeam. 1984. Calcium as a plant nutrient. Plant, Cell and Environ. 7:397-405.

Lagowski, J.M., H.M. Sell, C.F. Huffman and C.W. Duncan. 1958. The carbohydrates in alfalfa Medicago sativa. I. General composition, identification of a nonreducing sugar and investigation of the pectic substances, Arch. Biochem. Biophys. 76:306-316.

Larry, M. W. and J. R. Wight. 1984. Forage yield and quality of dryland grasses and legumes. J. of Range Mang. 37:233-236.

Liu, M., D.E. Kissel, P.F. Vendrell and M.L. Cabrera. 2004. Soil lime requirement by direct titration with calcium hydroxide. Soil Sci. Soc. Am. J. 68:1228-1233.

Loneragan, J.F. and K. Snoball. 1969a. Calcium requirements of plants. Aust. J. Agr. Res. $20: 465-478$.

Lubowski, R.N., M. Vesterby, S. Bucholtz, A. Baez and M.J. Roberts. 2006. Major uses of land in the United States, 2002. Rep. 14. Economic Research Services, USDA.

Maas, E.V. 1969. Calcium uptake by excised maize roots and interactions with alkali cations. Plant Physiol. 44:985-989.

Mackay, A.D. and S. A. Barber. 1985. Soil moisture effects on root growth and phosphorus uptake by corn. Agron. J. 77:519-523.

Magdoff, F.R. and R.J. Bartlett. 1985. Soil pH buffering revisited. Soil Sci. Soc. Am. Proc. 49:145-148. 
Moore, K.J., L.E. Moser, K.P. Vogel, S.S. Waller, B.E. Johnson and J.F. Pedersen. 1991. Describing and quantifying growth stages of perennial forage grasses. Agron. J. 83:10731077.

NASS. 2005. National Agricultural Statistics Service. [Online.] Available at. http://www.nass.usda.gov/. (Accessed 10 January 2010).

NEC-67. 1995. Northeast coordinating committee on soil testing 1995. Recommended Soil Testing Procedures for the Northeastern United States. Northeastern Regional Publication No.493. Agricultural Experiment Station, University of Delaware.

Nelson, D.W. and L.E. Sommers. 1996. Total carbon, organic carbon, and organic matter. p. 961-1010. In Methods of Soil Analysis Part 2, 2nd edition (ed.) A.L. Page et al. Am. Soc. Agron. Madison, WI.

Nielsen, D.C. 2004. Kenaf forage yield and quality under varying water availability. Agron. J. 96:204-213.

Osemwota, I.O., A.I. Ogboghodo and J.A.I. Omueti. 2007. Effect of Calcium/Magnesium ratio in soil on magnesium availability, yield, and yield components of maize. Commun. Soil Sci. Plant Anal. 38:2849-2860.

Pearson, C.J. and R.L. Ison. 1997. Agronomy of Grassland Systems. Cambridge University Press, NY.

Poppi, D.P., S.R. McLennan, S. Bediye, A. de Vega and J. Zorrila-Rios. 1999. Forage quality: Strategies for increasing nutritive value of forages. p. 307-322. In J.G. Buchanon-Smith, L.D. Bailey and P. McCaughey (eds.) XVIII International Grassland Congress, Winnipeg 
and Saskatoon, Calgary, Canada. June 8-17 1999. Association Management Centre, Canada.

Rincon, M. and J.B. Hanson. 1986. Controls on calcium ion fluxes in injured or shocked corn root cells: Importance of proton pumping and cell membrane potential. Physiol. Plantarum 67:576-583.

Ripp, J. 1996. Analytical detection limit guidance and laboratory guide for determining method detection limits. Rep. PUBL-TS-056-96. Wisconsin Department of Natural Resources, Madison, WI.

Ritchey, K.D. and J.D. Snuffer. 2002. Limestone, gypsum, and magnesium oxide influence restoration of an abandoned Appalachian pasture. Agron. J. 94:830-839.

Sanik, J. 1952. The effect of Ca: Mg ratio on availability of plant nutrients. Soil Sci. Soc. Am. Proc. 16:263-267.

SAS Institute. 2002. The SAS systems for Windows. Release version 9.1. SAS Institute Inc. Cary, NC.

Schofleld, R. K. and A. W. Taylor. 1955. The measurement of soil pH. Soil Sci. Soc. Am. Proc. 19:164-167.

Seguin, P., A.F. Mustafa and C.C. Sheaffer. 2002. Effects of soil moisture deficit on forage quality, digestibility, and protein fractionation of kura clover. J. Agron. Crop Sci. 188:260-266. 
Sims, J.T. 1992. Lime requirement. p. 491-516. In In D.L. Sparks (ed.) Methods of Soil Analysis. Part3- Chemical Methods. SSSA Book Series no.5. American Society of Agronomy, Madison, WI.

Soil Survey Staff, Natural Resources Conservation Service, United States Department of Agriculture. Official Soil Series Descriptions. [Online.] Available at. http://www2.ftw.nrcs.usda.gov/osd/dat/E/ERNEST.html. ( Accessed 10 May 2010). USDA- NRCS, Lincoln, NE.

Stern, M.O. and M. J. Endres. 1991. Uronic acid assay. p. 28-36. In Research Techniques in Ruminant Nutrition. Dep. Of Animal Science, University Of Minnesota.

Tedeschi, L.O., A.N. Pell, D.G. Fox and C.R. Llames. 2001. The amino acid profiles of the whole plant and of four plant residues from temperate and tropical forages. J. Anim. Sci. 79:525-532.

Tester, M. 1990. Plant ion channels: Whole-cell and single-channel studies. New Phytol 114:305-340.

Thom, D., G.T. Grant, E.R. Morris and D.A. Rees. 1982. Characterisation of cation binding and gelation of polyuronates by circular dichroism. Carbohydr. Res. 100:29-42.

Tilman, D., M.E. Dodd, J. Silvertown, P.R. Poulton, A.E. Johnston and M.J. Crawley. 1994. The Park Grass experiment: Insights from the most long-term ecological study. p. 287-303. In R.A. Leigh and A.E. Johnston (ed.) Long-term Experiments in Agricultural and Ecological Sciences, Wallingford. 1994. CAB International, . 
Tran, H., P. Lecomte and P. Salgado. 2009. Species, climate and fertilizer effects on grass fibre and protein in tropical environments J. Agric. Sci. 147:555-568.

Trlica, M.J. 1999. Grass growth and response to grazing. Rep. 6.108. Colorado State University Cooperative Extension, Fort Collins, CO.

Truog, E. 1948. Lime in relation to availability of plant nutrients. Soil Sci. 65:1-8.

U.S. Environmental Protection Agency (EPA). 1994. Test methods for evaluating solid waste . In SW-846, 3rd ed., ed. Office of Solid Waste and Emergency Response, Washington, D.C.

Ulrich, B. 1994. Nutrient and acid-base budget of central European forest ecosystems. p. 1-50. In D L Godbold and A Hüttermann (eds.) Effects of Acid Rain on Forest Processes. Wiley Liss, New York.

Watson, R.N., F. J. Neville and N. L. Bell. 1998. Caucasian clover performance in a year of severe drought. Proc. NZ Grassl. Assoc. 60:119-125.

Weaver, A.R., D.E. Kissel, F. Chen, L.T. West, W. Adkins, D. Rickman and J.C. Luvall. 2004. Mapping soil pH buffering capacity of selected fields in the coastal plain. Soil Sci. Soc. Am. J. 68:662-668.

Wheeler, D.M. and D. C. Edmeades. 1995. Effect of varying solution calcium or magnesium concentrations in the presence or absence of aluminum on yield and plant calcium or magnesium concentrations in wheat. J. Plant Nutr. 18:2229-2245.

Whitney, D.A. 1998. Soil salinity. p. 59. In Recommended Chemical Soil Test Procedures for the North Central Region. Res. Publ. No. 221 (revised). Jan. 1998. Missouri Agri. Exp. Stn. Columbia, MO. 


\section{Tables and Figures}

Table 3.1. Soil physical and chemical properties prior to liming treatment application.

\begin{tabular}{|c|c|c|c|}
\hline Parameter & Unit & Mean & Std Dev \\
\hline $\mathrm{pH}$ & & 5.7 & 0.15 \\
\hline Sand & $\%$ & 23 & 0.19 \\
\hline Silt & $\%$ & 40 & 1.42 \\
\hline Clay & $\%$ & 37 & 1.48 \\
\hline Total Carbon & $\%$ & 2.5 & 0.15 \\
\hline Total Nitrogen & $\%$ & 0.2 & 0.02 \\
\hline CEC & $\mathrm{cmol}_{\mathrm{c}} / \mathrm{kg}$ & 8 & 0.23 \\
\hline Exchangeable $\mathrm{Ca}$ & $\mathrm{cmol}_{\mathrm{C}} / \mathrm{kg}$ & 6.0 & 0.2 \\
\hline Exchangeable Mg & $\mathrm{cmol}_{\mathrm{C}} / \mathrm{kg}$ & 0.9 & 0.05 \\
\hline Exchangeable K & $\mathrm{cmol}_{\mathrm{c}} / \mathrm{kg}$ & 0.3 & 0.06 \\
\hline Exchangeable Al & $\mathrm{cmol}_{\mathrm{C}} / \mathrm{kg}$ & 0.2 & 0.01 \\
\hline Exchangeable $\mathrm{H}$ & $\mathrm{cmol}_{\mathrm{c}} / \mathrm{kg}$ & 3.5 & 0.14 \\
\hline Mehlich I Ca & $\mathrm{mg} / \mathrm{kg}$ & 1265 & 6.91 \\
\hline Mehlich I Mg & $\mathrm{mg} / \mathrm{kg}$ & 98 & 1.09 \\
\hline Mehlich I P & $\mathrm{mg} / \mathrm{kg}$ & 39 & 4.86 \\
\hline Mehlich I K & $\mathrm{mg} / \mathrm{kg}$ & 116 & 0.08 \\
\hline DTPA Cu & $\mathrm{mg} / \mathrm{kg}$ & 1 & 0.02 \\
\hline DTPA Fe & $\mathrm{mg} / \mathrm{kg}$ & 101 & 0.18 \\
\hline DTPA Mn & $\mathrm{mg} / \mathrm{kg}$ & 39 & 0.36 \\
\hline DTPA Zn & $\mathrm{mg} / \mathrm{kg}$ & 0.92 & 0.06 \\
\hline
\end{tabular}


Table 3.2. Soil test (Mehlich1) Ca and Mg concentrations (mg/kg soil), their sufficiency range and the resulting $\mathrm{Ca}$ : $\mathrm{Mg}$ ratios in the soil.

\begin{tabular}{|c|c|c|c|}
\hline $\mathrm{Ca}(\mathrm{OH})_{2}-\mathrm{Mg}(\mathrm{OH})_{2}$ & Soil Test Ca & Soil Test Mg & $\mathrm{Ca} / \mathrm{Mg}$ Ratio in Soil \\
\hline Treatment Combination (\%) & $\mathrm{mg} / \mathrm{kg}$ & $\mathrm{mg} / \mathrm{kg}$ & \\
\hline $0-100$ & 1265 (Medium-High) & 282(High) & $4: 1$ \\
\hline $25-75$ & 1331(High) & 228(High) & $6: 1$ \\
\hline $50-50$ & 1451(High) & 200(High) & $7: 1$ \\
\hline $60-40$ & 1470(High) & 176(High) & $8: 1$ \\
\hline $70-30$ & 1536(High) & 151(High) & $10: 1$ \\
\hline $75-25$ & 1554(High) & 143(High) & $11: 1$ \\
\hline $80-20$ & 1573(High) & 134(High) & $12: 1$ \\
\hline $90-10$ & 1631(High) & 120(High) & $14: 1$ \\
\hline $100-0$ & 1632(High) & 98(Medium-High) & $17: 1$ \\
\hline
\end{tabular}


Table 3.3. ANOVA output for herbage accumulation of sudangrass and red clover.

\begin{tabular}{|c|c|c|c|c|}
\hline Tissue & Source & Sum of Squares & Mean Square & $\mathrm{P}>\mathrm{F}$ \\
\hline \multicolumn{5}{|c|}{ Sudangrass } \\
\hline & Model & 1710.87 & 100.64 & $<0.0001$ \\
\hline & $\mathrm{Ca} / \mathrm{Mg}$ ratio (Ratio) & 558.00 & 69.75 & $<0.0001$ \\
\hline & Water Potential (WP) & 1035.03 & 1035.03 & $<0.0001$ \\
\hline & Ratio $\times \mathrm{WP}$ & 117.84 & 14.73 & 0.1646 \\
\hline \multicolumn{5}{|c|}{ Red clover } \\
\hline & Model & 130.85 & 7.70 & $<0.0001$ \\
\hline & $\mathrm{Ca} / \mathrm{Mg}$ ratio (Ratio) & 26.50 & 3.31 & 0.1388 \\
\hline & Water Potential (WP) & 98.81 & 98.81 & $<0.0001$ \\
\hline & Ratio $\times$ WP & 5.55 & 0.69 & 0.9493 \\
\hline
\end{tabular}


Table 3.4. ANOVA outout for crude protein percentage in sudangrass young leaf blade, sudangrass old leaf blade and red clover.

\begin{tabular}{|c|c|c|c|c|}
\hline Tissue & Source & $\begin{array}{c}\text { Sum of } \\
\text { Squares }\end{array}$ & $\begin{array}{c}\text { Mean } \\
\text { Square }\end{array}$ & $\mathrm{P}>\mathrm{F}$ \\
\hline \multicolumn{5}{|c|}{ Young Leaf Sudangrass } \\
\hline & Model & 105.53 & 6.21 & $<0.0001$ \\
\hline & $\mathrm{Ca} / \mathrm{Mg}$ ratio (Ratio) & 51.11 & 6.39 & $<0.0001$ \\
\hline & Water Potential (WP) & 48.39 & 48.39 & $<0.0001$ \\
\hline & Ratio $\times$ WP & 6.03 & 0.75 & 0.2455 \\
\hline
\end{tabular}

Old Leaf Sudangrass

$\begin{array}{lccc}\text { Model } & 100.31 & 5.9 & <0.0001 \\ \mathrm{Ca} / \mathrm{Mg} \text { ratio (Ratio) } & 44.4 & 5.55 & <0.0001 \\ \text { Water Potential (WP) } & 43.81 & 43.81 & <0.0001 \\ \text { Ratio } \times \mathrm{WP} & 12.1 & 1.51 & 0.0644\end{array}$

Red Clover

\begin{tabular}{lccc} 
Model & 617.34 & 36.34 & 0.0001 \\
$\mathrm{Ca} / \mathrm{Mg}$ ratio (Ratio) & 432.5 & 54.06 & 0.0001 \\
Water Potential (WP) & 142.03 & 142.03 & 0.0001 \\
Ratio $\times \mathrm{WP}$ & 43.31 & 5.41 & 0.0003 \\
\hline
\end{tabular}


Table 3.5. Model observed significance levels of $\mathrm{Ca}, \mathrm{Mg}, \mathrm{P}$, and $\mathrm{K}$ for sudangrass young leaf blade, sudangrass old leaf blade, and red clover.

\begin{tabular}{|c|c|c|c|c|c|}
\hline Tissue & Source & $\underline{\mathrm{Ca}}$ & $\underline{\mathrm{Mg}}$ & $\underline{\mathrm{P}}$ & $\underline{\mathrm{K}}$ \\
\hline & & -------------- & ---------- & F---------- & -------------. \\
\hline \multicolumn{6}{|c|}{ Young Leaf Sudangrass } \\
\hline & Ratio & $<0.0001$ & $<0.0001$ & 0.077 & $<0.0001$ \\
\hline & WP & $<0.0001$ & $<0.0001$ & 0.2241 & 0.5179 \\
\hline & Ratio $\times \mathrm{WP}$ & 0.0262 & 0.0957 & 0.7985 & 0.1483 \\
\hline \multicolumn{6}{|c|}{ Old Leaf Sudangrass } \\
\hline & Ratio & $<0.0001$ & $<0.0001$ & 0.0499 & $<0.0001$ \\
\hline & WP & $<0.0001$ & $<0.0001$ & $<0.0001$ & $<0.0001$ \\
\hline & Ratio $\times$ WP & 0.2453 & 0.2843 & 0.4198 & 0.5914 \\
\hline \multicolumn{6}{|c|}{ Red Clover } \\
\hline & Ratio & $<0.0001$ & $<0.0001$ & $<0.0001$ & $<0.0021$ \\
\hline & WP & $<0.0001$ & $<0.0001$ & $<0.0001$ & $<0.0001$ \\
\hline & Ratio $\times$ WP & 0.3705 & 0.133 & 0.9118 & 0.0611 \\
\hline
\end{tabular}


Table 3.6a. Mean herbage accumulation (whole plant), crude protein, $\mathrm{Ca}, \mathrm{Mg}, \mathrm{P}$ and $\mathrm{K}$ concentration in sudangrass young leaf blade and sudangrass old leaf blade at each water potential.

\begin{tabular}{|c|c|c|c|c|c|c|c|c|c|c|c|c|}
\hline \multirow[b]{2}{*}{ Factor } & \multirow[b]{2}{*}{ Level } & \multicolumn{7}{|c|}{ Young leaf blade } & \multicolumn{3}{|c|}{ Old leaf blade } & \multirow[b]{2}{*}{$\mathrm{K}$} \\
\hline & & $\begin{array}{c}\text { Dry } \\
\text { Matter }\end{array}$ & $\begin{array}{l}\text { Crude } \\
\text { Protein }\end{array}$ & $\mathrm{Ca}$ & $\mathrm{Mg}$ & $\mathrm{P}$ & $\mathrm{K}$ & $\begin{array}{c}\text { Crude } \\
\text { Protein }\end{array}$ & $\mathrm{Ca}$ & $\mathrm{Mg}$ & $\mathrm{P}$ & \\
\hline \multirow[t]{2}{*}{ Water Potential } & $\mathrm{H}$ & $25.24 \mathrm{a}$ & $7.42 \mathrm{a}$ & $0.32 \mathrm{a}$ & $0.25 \mathrm{a}$ & $0.20 \mathrm{a}$ & $0.98 \mathrm{a}$ & $6.16 \mathrm{a}$ & $0.62 \mathrm{a}$ & $0.41 \mathrm{a}$ & $0.14 \mathrm{a}$ & $0.50 \mathrm{a}$ \\
\hline & $\mathrm{L}$ & $18.46 b$ & $8.88 b$ & $0.23 b$ & $0.20 \mathrm{~b}$ & $0.19 \mathrm{a}$ & $0.99 \mathrm{a}$ & $7.58 \mathrm{~b}$ & $0.48 b$ & $0.31 \mathrm{~b}$ & $0.07 b$ & $0.71 b$ \\
\hline $\operatorname{LSD}(0.05)$ & & 1.31 & 0.32 & 0.01 & 0.01 & 0.01 & 0.04 & 0.37 & 0.02 & 0.02 & 0.01 & 0.04 \\
\hline
\end{tabular}

Note. Within same column and for a given main effect, means followed by same letter are not significantly different at $\mathrm{P}<0.05$. 
Table 3.6b. Mean herbage accumulation (whole plant), crude protein, $\mathrm{Ca}, \mathrm{Mg}, \mathrm{P}$ and $\mathrm{K}$ concentration in sudangrass young leaf blade and sudangrass old leaf blade at each $\mathrm{Ca} / \mathrm{Mg}$ ratio.

\begin{tabular}{|c|c|c|c|c|c|c|c|c|c|c|c|c|}
\hline \multirow[b]{2}{*}{ Factor } & \multirow[b]{2}{*}{ Level } & \multicolumn{6}{|c|}{ Young leaf blade } & \multicolumn{5}{|c|}{ Old leaf blade } \\
\hline & & $\begin{array}{c}\text { Dry } \\
\text { Matter }\end{array}$ & $\begin{array}{c}\text { Crude } \\
\text { Protein }\end{array}$ & $\mathrm{Ca}$ & $\mathrm{Mg}$ & $\mathrm{P}$ & $\mathrm{K}$ & $\begin{array}{c}\text { Crude } \\
\text { Protein }\end{array}$ & $\mathrm{Ca}$ & $\mathrm{Mg}$ & $\mathrm{P}$ & $\mathrm{K}$ \\
\hline \multirow[t]{9}{*}{$\mathrm{Ca} / \mathrm{Mg}$ Ratio } & 4 & $23.88 \mathrm{ab}$ & $8.74 \mathrm{ab}$ & $0.22 \mathrm{~d}$ & $0.22 b c$ & $0.18 b$ & $0.98 b$ & $8.48 \mathrm{a}$ & $0.58 \mathrm{a}$ & $0.47 \mathrm{a}$ & $0.10 \mathrm{abc}$ & $0.61 b c$ \\
\hline & 6 & $24.03 \mathrm{ab}$ & $8.12 b d c$ & $0.29 b c$ & $0.28 \mathrm{a}$ & $0.18 b$ & $0.95 b$ & $6.95 b c$ & $0.56 a b c$ & $0.44 \mathrm{a}$ & $0.11 \mathrm{ab}$ & $0.60 \mathrm{bc}$ \\
\hline & 7 & $19.34 \mathrm{~cd}$ & $8.92 \mathrm{a}$ & $0.22 \mathrm{~d}$ & $0.21 \mathrm{bcd}$ & $0.20 b$ & $1.00 \mathrm{~b}$ & $6.67 \mathrm{c}$ & $0.48 \mathrm{~d}$ & $0.33 \mathrm{bc}$ & $0.12 \mathrm{ab}$ & $0.61 b c$ \\
\hline & 8 & $19.76 \mathrm{~cd}$ & $7.70 \mathrm{~d}$ & $0.26 \mathrm{c}$ & $0.23 b c$ & $0.19 b$ & $0.95 b$ & $6.62 \mathrm{~cd}$ & $0.52 \mathrm{~cd}$ & $0.35 b$ & $0.09 b c$ & $0.56 b c$ \\
\hline & 10 & $23.75 \mathrm{ab}$ & $7.83 \mathrm{dc}$ & $0.26 \mathrm{~cd}$ & $0.23 b$ & $0.20 b$ & $0.98 b$ & $6.82 \mathrm{bc}$ & $0.53 b c$ & $0.35 b$ & $0.10 \mathrm{bc}$ & $0.53 \mathrm{c}$ \\
\hline & 11 & $22.02 b c$ & 8.37abcd & $0.35 \mathrm{a}$ & $0.27 \mathrm{a}$ & $0.20 b$ & $0.94 b$ & $5.84 d$ & $0.57 \mathrm{ab}$ & $0.33 b$ & $0.11 \mathrm{abc}$ & $0.59 \mathrm{bc}$ \\
\hline & 12 & $25.15 a$ & $8.44 \mathrm{abc}$ & $0.26 \mathrm{~cd}$ & $0.18 \mathrm{~d}$ & $0.19 b$ & $0.96 b$ & $6.31 \mathrm{~cd}$ & $0.59 a$ & $0.34 b$ & $0.09 \mathrm{c}$ & $0.52 \mathrm{c}$ \\
\hline & 14 & $21.51 b c$ & $8.83 \mathrm{a}$ & $0.28 b c$ & $0.18 \mathrm{~d}$ & $0.20 \mathrm{~b}$ & $0.96 b$ & $7.46 b$ & $0.58 \mathrm{a}$ & $0.31 b c$ & $0.11 \mathrm{abc}$ & $0.64 b$ \\
\hline & 17 & $17.18 \mathrm{~d}$ & $6.34 \mathrm{e}$ & $0.32 \mathrm{ab}$ & $0.2 \mathrm{~cd}$ & $0.24 \mathrm{a}$ & $1.16 \mathrm{a}$ & $6.75 b c$ & $0.57 \mathrm{ab}$ & $0.3 \mathrm{c}$ & $0.13 \mathrm{a}$ & $0.76 \mathrm{a}$ \\
\hline $\operatorname{LSD}(0.05)$ & & 2.77 & 0.67 & 0.04 & 0.03 & 0.03 & 0.09 & 0.78 & 0.05 & 0.04 & 0.03 & 0.09 \\
\hline
\end{tabular}

Note. Within same column and for a given main effect, means followed by same letter are not significantly different at $\mathrm{P}<0.05$. 
Table 3.7. Main effects of $\mathrm{Ca} / \mathrm{Mg}$ ratio and water potential on dry matter, crude protein concentration and tissue mineral concentrations in red clover.

\begin{tabular}{|c|c|c|c|c|c|c|c|}
\hline & & Dry Matter & Crude Protein & $\mathrm{Ca}$ & $\mathrm{Mg}$ & $\mathrm{P}$ & $\mathrm{K}$ \\
\hline & & -- g pot ${ }^{-1}$--- & ---------------- & -------- & $\%$ & --------- & ---------- \\
\hline Factor & Level & & & & & & \\
\hline \multirow[t]{2}{*}{ Water Potential } & $\mathrm{H}$ & $6.91 \mathrm{a}$ & $17.45 \mathrm{a}$ & $2.58 \mathrm{a}$ & $0.98 \mathrm{a}$ & $0.179 \mathrm{a}$ & $0.66 \mathrm{a}$ \\
\hline & $\mathrm{L}$ & $4.82 b$ & $19.97 b$ & $2.19 b$ & $0.86 b$ & $0.213 b$ & $0.89 b$ \\
\hline LSD (0.05) & & 0.60 & 0.48 & 0.06 & 0.01 & 0.01 & 0.03 \\
\hline \multirow[t]{9}{*}{$\mathrm{Ca} / \mathrm{Mg}$ Ratio } & 4 & & $16.01 \mathrm{~cd}$ & $2.25 \mathrm{c}$ & $0.97 b$ & $0.17 b$ & $0.76 a b c$ \\
\hline & 6 & & $15.09 \mathrm{~d}$ & $2.21 \mathrm{c}$ & $1.01 \mathrm{a}$ & $0.21 \mathrm{a}$ & $0.75 \mathrm{bcd}$ \\
\hline & 7 & & $18.26 \mathrm{~b}$ & $2.31 b c$ & $1.00 \mathrm{ab}$ & $0.18 b$ & $0.77 \mathrm{abc}$ \\
\hline & 8 & & $16.67 \mathrm{c}$ & $2.06 \mathrm{~d}$ & $0.90 \mathrm{~cd}$ & $0.21 \mathrm{a}$ & $0.84 a$ \\
\hline & 10 & & $20.33 a$ & $2.33 b c$ & $0.88 \mathrm{cde}$ & $0.18 b$ & $0.68 \mathrm{~d}$ \\
\hline & 11 & & $20.77 \mathrm{a}$ & $2.71 \mathrm{a}$ & $0.89 \mathrm{cde}$ & $0.20 \mathrm{a}$ & $0.82 \mathrm{ab}$ \\
\hline & 12 & & $19.11 b$ & $2.40 \mathrm{~b}$ & $0.87 \mathrm{de}$ & $0.21 \mathrm{a}$ & $0.84 \mathrm{a}$ \\
\hline & 14 & & $20.85 a$ & $2.72 \mathrm{a}$ & $0.85 \mathrm{e}$ & $0.18 b$ & $0.76 a b c$ \\
\hline & 17 & & $21.32 \mathrm{a}$ & $2.45 b$ & $0.92 \mathrm{c}$ & $0.18 b$ & $0.73 \mathrm{~cd}$ \\
\hline LSD (0.05) & & & 1.01 & 0.14 & 0.04 & 0.01 & 0.08 \\
\hline
\end{tabular}

Note. Within same column and for a given main effect, means followed by same letter are not significantly different at $\mathrm{P}<0.05$. 
Table 3.8. Mean and standard error (SE) for Water Potential (High or Low) and Ca/Mg Ratio for red clover dry matter yield.

\begin{tabular}{|c|c|c|c|c|}
\hline \multirow{3}{*}{$\begin{array}{c}\text { Soil } \\
\mathrm{Ca} / \mathrm{Mg} \text { Ratio }\end{array}$} & \multicolumn{4}{|c|}{ Dry Matter Yield } \\
\hline & \multicolumn{2}{|c|}{ High } & \multicolumn{2}{|c|}{ Low } \\
\hline & Mean & SE & Mean & SE \\
\hline 4 & 6.99 & 0.19 & 5.10 & 0.20 \\
\hline 6 & 5.97 & 0.40 & 4.37 & 0.21 \\
\hline 7 & 7.09 & 0.66 & 5.13 & 0.43 \\
\hline 8 & 6.22 & 0.85 & 4.48 & 0.13 \\
\hline 10 & 7.64 & 0.37 & 6.10 & 0.33 \\
\hline 11 & 8.06 & 1.97 & 4.88 & 0.56 \\
\hline 12 & 6.77 & 0.44 & 4.48 & 0.42 \\
\hline 14 & 6.96 & 0.34 & 4.90 & 0.46 \\
\hline 17 & 6.57 & 0.59 & 3.96 & 0.40 \\
\hline
\end{tabular}


Table 3.9. ANOVA output for pectin concentration in sudangrass young leaf blade, sudangrass old leaf blade, and red clover.

\begin{tabular}{|c|c|c|c|c|}
\hline Plant Part & Source & Sum of Squares & Mean Square & $\mathrm{P}>\mathrm{F}$ \\
\hline \multicolumn{5}{|c|}{ Young leaf blade sudangrass } \\
\hline & Model & 20.15 & 1.19 & $<.0001$ \\
\hline & $\mathrm{Ca} / \mathrm{Mg}$ ratio (Ratio) & 14.59 & 1.82 & $<.0001$ \\
\hline & Water Potential (WP) & 0.01 & 0.01 & 0.6747 \\
\hline & Ratio $\times$ WP & 5.55 & 0.69 & $<.0001$ \\
\hline \multicolumn{5}{|c|}{ Old leaf blade sudangrass } \\
\hline & Model & 30.98 & 1.82 & $<.0001$ \\
\hline & $\mathrm{Ca} / \mathrm{Mg}$ ratio (Ratio) & 14.04 & 1.75 & $<.0001$ \\
\hline & Water Potential (WP) & 0.71 & 0.71 & 0.1193 \\
\hline & Ratio $\times$ WP & 16.23 & 2.03 & $<.0001$ \\
\hline \multicolumn{5}{|l|}{ Red clover } \\
\hline & Model & 236.79 & 13.93 & $<.0001$ \\
\hline & $\mathrm{Ca} / \mathrm{Mg}$ ratio (Ratio) & 186.96 & 23.37 & $<.0001$ \\
\hline & Water Potential (WP) & 43.01 & 43.01 & $<.0001$ \\
\hline & Ratio $\times$ WP & 6.82 & 0.85 & 0.0426 \\
\hline
\end{tabular}


Table 3.10. ANOVA output for fiber components concentration in sudangrass young leaf blade, sudangrass old leaf blade, and red clover.

\begin{tabular}{|c|c|c|c|c|}
\hline & & $\underline{\mathrm{NDF}}$ & $\underline{\mathrm{ADF}}$ & ADL \\
\hline Plant Part & Source & $\mathrm{P}>\mathrm{F}$ & $\mathrm{P}>\mathrm{F}$ & $\mathrm{P}>\mathrm{F}$ \\
\hline \multicolumn{5}{|c|}{ Young leaf blade sudangrass } \\
\hline & Model & $<.0001$ & $<.0001$ & 0.0639 \\
\hline & $\mathrm{Ca} / \mathrm{Mg}$ ratio (Ratio) & 0.0018 & 0.0002 & 0.0216 \\
\hline & Water Potential (WP) & $<.0001$ & $<.0001$ & 0.3001 \\
\hline & Ratio $\times$ WP & 0.0756 & 0.1296 & 0.4257 \\
\hline \multicolumn{5}{|c|}{ Old leaf blade sudangrass } \\
\hline & Model & $<.0001$ & 0.0227 & 0.011 \\
\hline & $\mathrm{Ca} / \mathrm{Mg}$ ratio (Ratio) & 0.0606 & 0.756 & 0.0028 \\
\hline & Water Potential (WP) & $<.0001$ & $<.0001$ & 0.1256 \\
\hline & Ratio $\times$ WP & 0.3906 & 0.8778 & 0.4006 \\
\hline \multicolumn{5}{|l|}{ Red clover } \\
\hline & Model & $<.0001$ & $<.0001$ & $<.0001$ \\
\hline & $\mathrm{Ca} / \mathrm{Mg}$ ratio (Ratio) & 0.0957 & 0.0149 & $<.0001$ \\
\hline & Water Potential (WP) & $<.0001$ & $<.0001$ & 0.037 \\
\hline & Ratio $\times$ WP & 0.5148 & 0.6659 & 0.8127 \\
\hline
\end{tabular}


Table 3.11a. Main effects of water potential on fiber components in sudangrass and red clover.

\begin{tabular}{|c|c|c|c|c|c|c|c|c|}
\hline & \multicolumn{5}{|c|}{ sudangrass } & \multicolumn{3}{|c|}{ red clover } \\
\hline & \multicolumn{2}{|c|}{ Young leaf blade } & \multicolumn{3}{|c|}{ Old leaf blade } & \multirow[b]{2}{*}{$\mathrm{NDF}$} & \multirow[b]{2}{*}{$\mathrm{ADF}$} & \multirow[b]{2}{*}{ ADL } \\
\hline & NDF & $\mathrm{ADF}$ & NDF & $\mathrm{ADF}$ & ADL & & & \\
\hline \multicolumn{9}{|c|}{ Water potential } \\
\hline $\mathrm{H}$ & 71.71a & 33.85 & $65.25 \mathrm{a}$ & $31.1 \mathrm{a}$ & $3.06 \mathrm{a}$ & $31.17 \mathrm{a}$ & $19.53 \mathrm{a}$ & $3.08 \mathrm{a}$ \\
\hline $\mathrm{L}$ & $69.40 \mathrm{~b}$ & 31.82 & $61.17 \mathrm{~b}$ & $29.37 b$ & $2.75 a$ & $27.25 b$ & $17.08 \mathrm{~b}$ & $2.77 b$ \\
\hline LSD (0.05) & 0.46 & 0.49 & 0.90 & 0.80 & 0.41 & 0.75 & 0.58 & 0.29 \\
\hline
\end{tabular}

Note. Within same column and for a given main effect, means followed by same letter are not significantly different at $\mathrm{P}<0.05$. 
Table 3.11b. Main effects of $\mathrm{Ca} / \mathrm{Mg}$ ratio on fiber components in sudangrass and red clover.

\begin{tabular}{|c|c|c|c|c|c|c|c|c|}
\hline & \multicolumn{5}{|c|}{ sudangrass } & \multicolumn{3}{|c|}{ red clover } \\
\hline & \multicolumn{2}{|c|}{$\underline{\text { Young leaf blade }}$} & \multicolumn{3}{|c|}{$\underline{\text { Old leaf blade }}$} & \multirow[b]{2}{*}{ NDF } & \multirow[b]{2}{*}{$\mathrm{ADF}$} & \multirow[b]{2}{*}{ ADL } \\
\hline & NDF & $\mathrm{ADF}$ & NDF & $\mathrm{ADF}$ & ADL & & & \\
\hline \multicolumn{9}{|l|}{$\mathrm{Ca} / \mathrm{Mg}$ Ratio } \\
\hline 4 & $69.98 \mathrm{~cd}$ & $32.94 b c$ & $63.07 \mathrm{ab}$ & $30.42 \mathrm{a}$ & $2.54 \mathrm{c}$ & $29.43 \mathrm{abc}$ & $18.28 \mathrm{bc}$ & $2.09 \mathrm{c}$ \\
\hline 6 & $70.37 \mathrm{bcd}$ & $32.92 b c$ & $61.27 b$ & $29.41 \mathrm{a}$ & $3.15 \mathrm{abc}$ & $30.35 \mathrm{a}$ & $19.54 \mathrm{a}$ & $3.39 \mathrm{a}$ \\
\hline 7 & $71.46 \mathrm{a}$ & $32.70 b c$ & $63.91 \mathrm{a}$ & $30.62 \mathrm{a}$ & $2.80 \mathrm{bc}$ & $28.48 b c$ & $17.99 \mathrm{c}$ & $2.76 b$ \\
\hline 8 & $70.19 \mathrm{~cd}$ & $32.57 b c$ & $62.82 \mathrm{ab}$ & $30.19 a$ & $3.92 \mathrm{a}$ & $29.80 \mathrm{ab}$ & $19.25 \mathrm{ab}$ & $3.41 \mathrm{a}$ \\
\hline 10 & 70.79abc & $32.27 b c$ & $63.28 \mathrm{a}$ & $30.27 \mathrm{a}$ & $3.08 \mathrm{abc}$ & $29.49 \mathrm{ab}$ & $18.41 \mathrm{abc}$ & $3.10 \mathrm{ab}$ \\
\hline 11 & $70.09 \mathrm{~cd}$ & $31.97 \mathrm{c}$ & $62.82 \mathrm{ab}$ & $30.10 \mathrm{a}$ & $2.40 \mathrm{c}$ & $29.44 \mathrm{abc}$ & $17.41 \mathrm{c}$ & $1.95 \mathrm{c}$ \\
\hline 12 & 71.29ab & $33.10 \mathrm{~b}$ & $63.11 \mathrm{ab}$ & $31.07 \mathrm{a}$ & $2.40 \mathrm{c}$ & $28.58 b c$ & $17.63 \mathrm{c}$ & $3.18 \mathrm{ab}$ \\
\hline 14 & $69.63 d$ & $32.35 b c$ & $64.66 \mathrm{a}$ & $30.66 \mathrm{a}$ & $3.53 \mathrm{ab}$ & $27.89 \mathrm{c}$ & $18.03 b c$ & $3.47 \mathrm{a}$ \\
\hline 17 & 71.18ab & $34.69 \mathrm{a}$ & $63.92 \mathrm{a}$ & $30.77 \mathrm{a}$ & $2.33 c$ & $29.47 \mathrm{abc}$ & $18.19 b c$ & $3.02 \mathrm{ab}$ \\
\hline LSD (0.05) & 0.98 & 1.05 & 1.90 & 1.71 & 0.86 & 1.60 & 1.22 & 0.61 \\
\hline
\end{tabular}

Note. Within same column and for a given main effect, means followed by same letter are not significantly different at $\mathrm{P}<0.05$. 


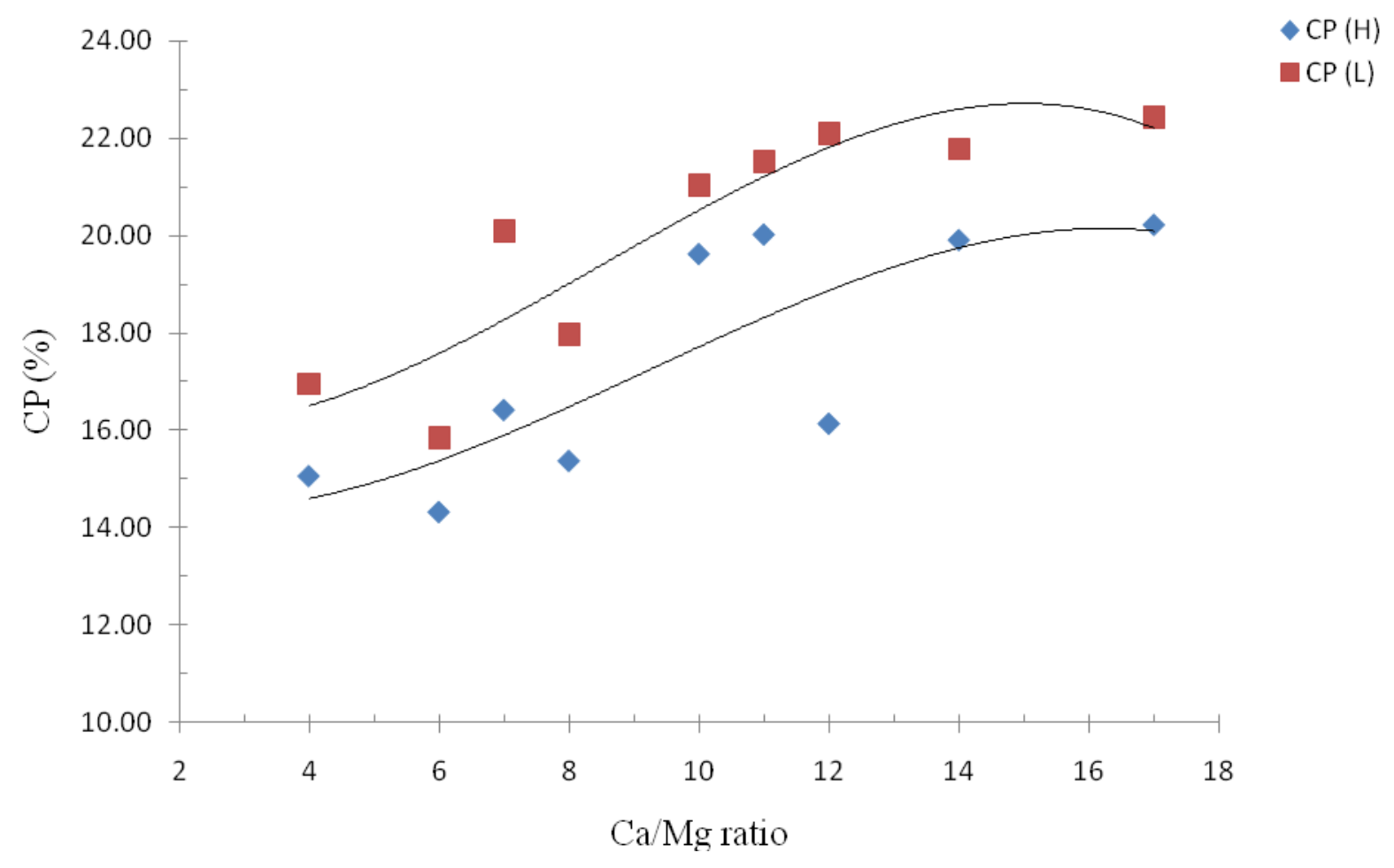

Figure 3.1. Crude protein (\%) of red clover across nine Ca: $\mathrm{Mg}$ ratio and two water potential treatments. $\mathrm{CP}(\mathrm{H})$ represents crude protein (\%) in frequently irrigated condition and CP (L) represents crude protein (\%) in poorly irrigated condition. Solid line represents fitted trend line (polynomial) through all ratios. Fischer's least significant difference for each water potential at given $\mathrm{Ca} / \mathrm{Mg}$ ratios are: 0.97 (4:1), 0.88 (6:1), 1.92 (7:1), 1.67 (8:1), 1.43 (10:1), 1.13 (11:1), 3.07 (12:1), 1.13 (14:1), $1.52(17: 1)$. 

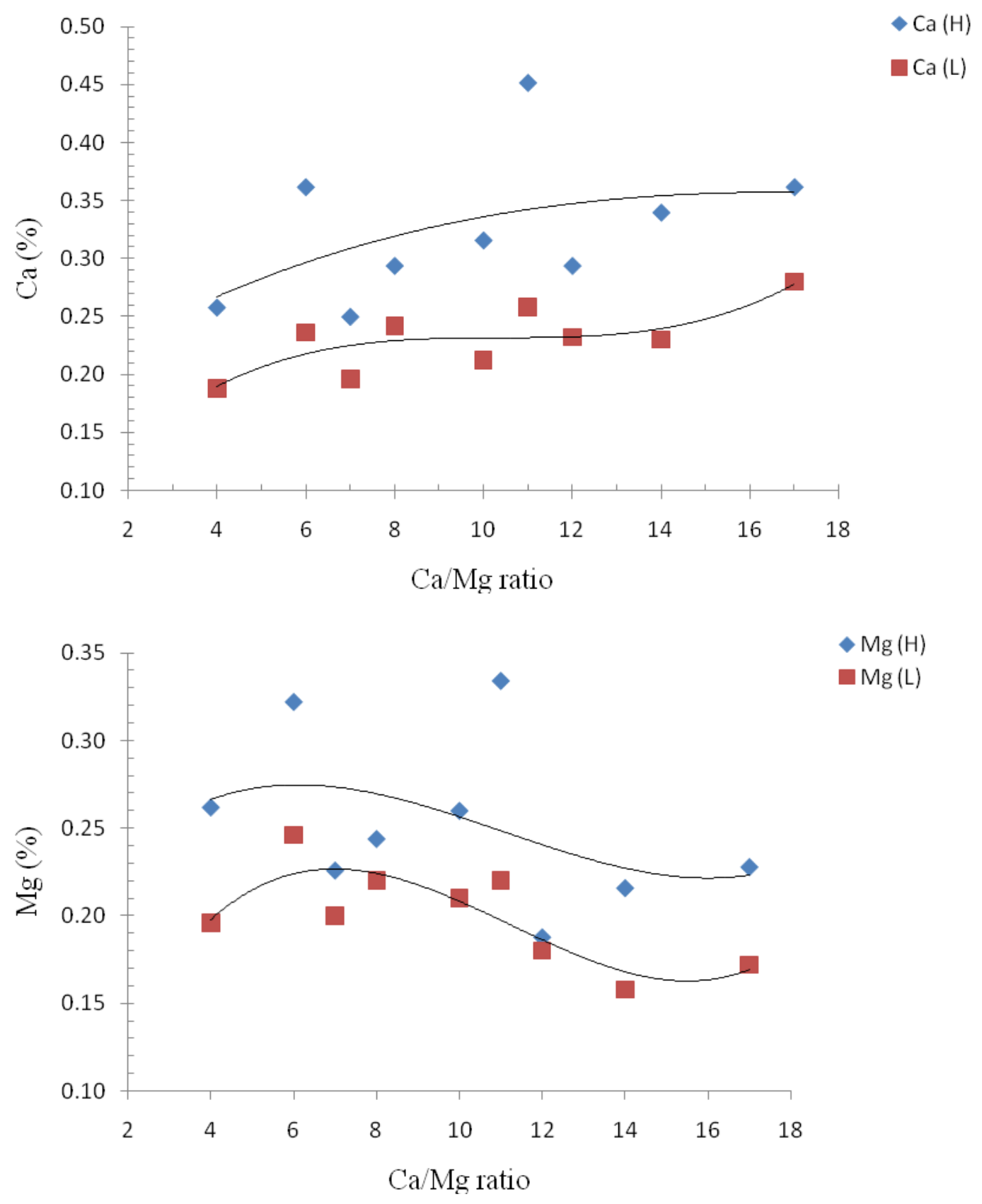

Figure 3.2. Tissue $\mathrm{Ca}$ and $\mathrm{Mg}(\%)$ in young leaf blade of sudangrass across nine $\mathrm{Ca} / \mathrm{Mg}$ ratio and two water potential. $\mathrm{H}$ represents frequently irrigated condition and L poorly irrigated condition. Solid line represents fitted trend line (polynomial) through all ratios. 

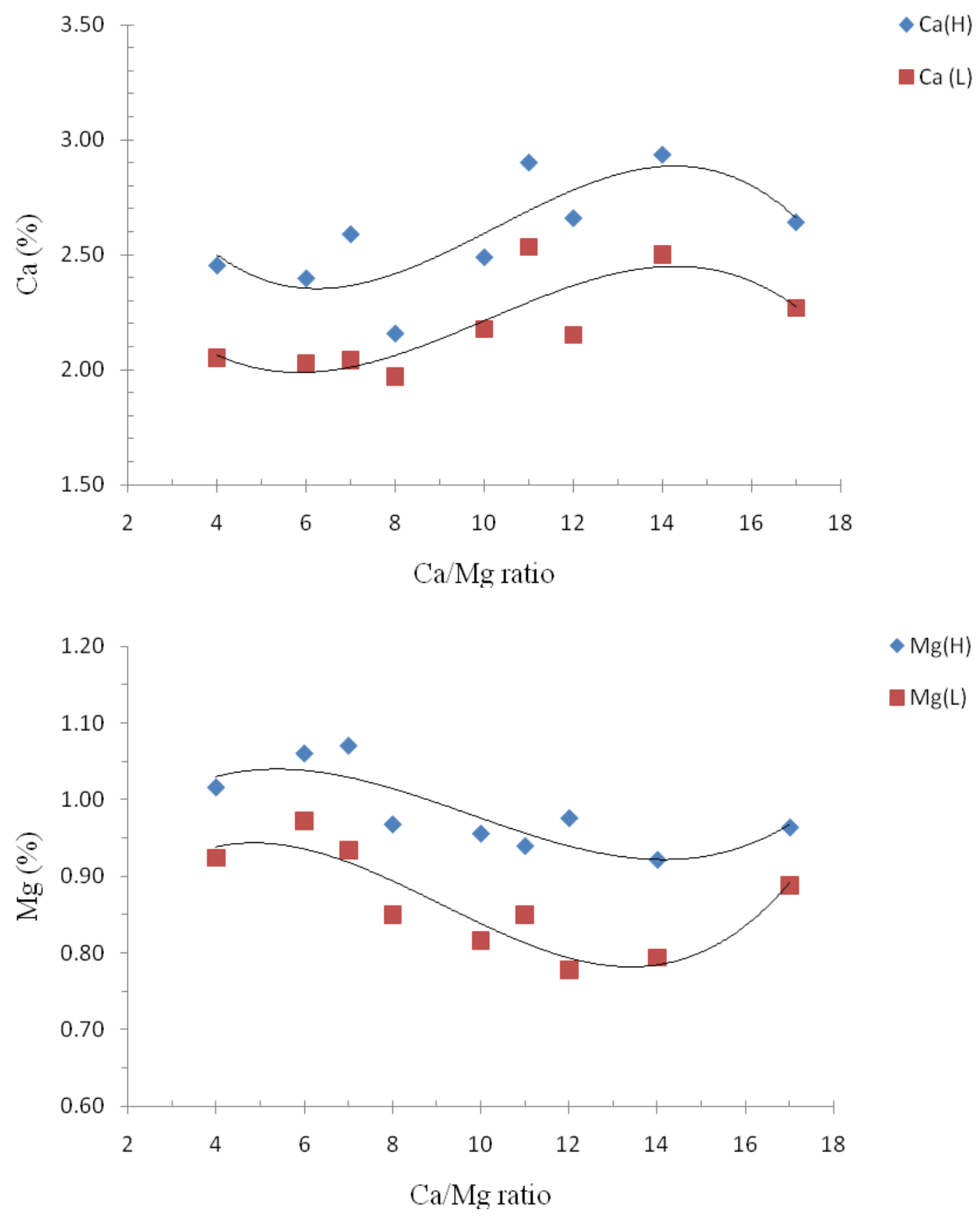

Figure 3.3. Tissue $\mathrm{Ca}$ and $\mathrm{Mg}(\%)$ in red clover across nine $\mathrm{Ca} / \mathrm{Mg}$ ratio and two water potential. $\mathrm{H}$ represents frequently irrigated condition and $\mathrm{L}$ represents poorly irrigated condition. Solid line represents fitted trend line (polynomial) through all ratios. 


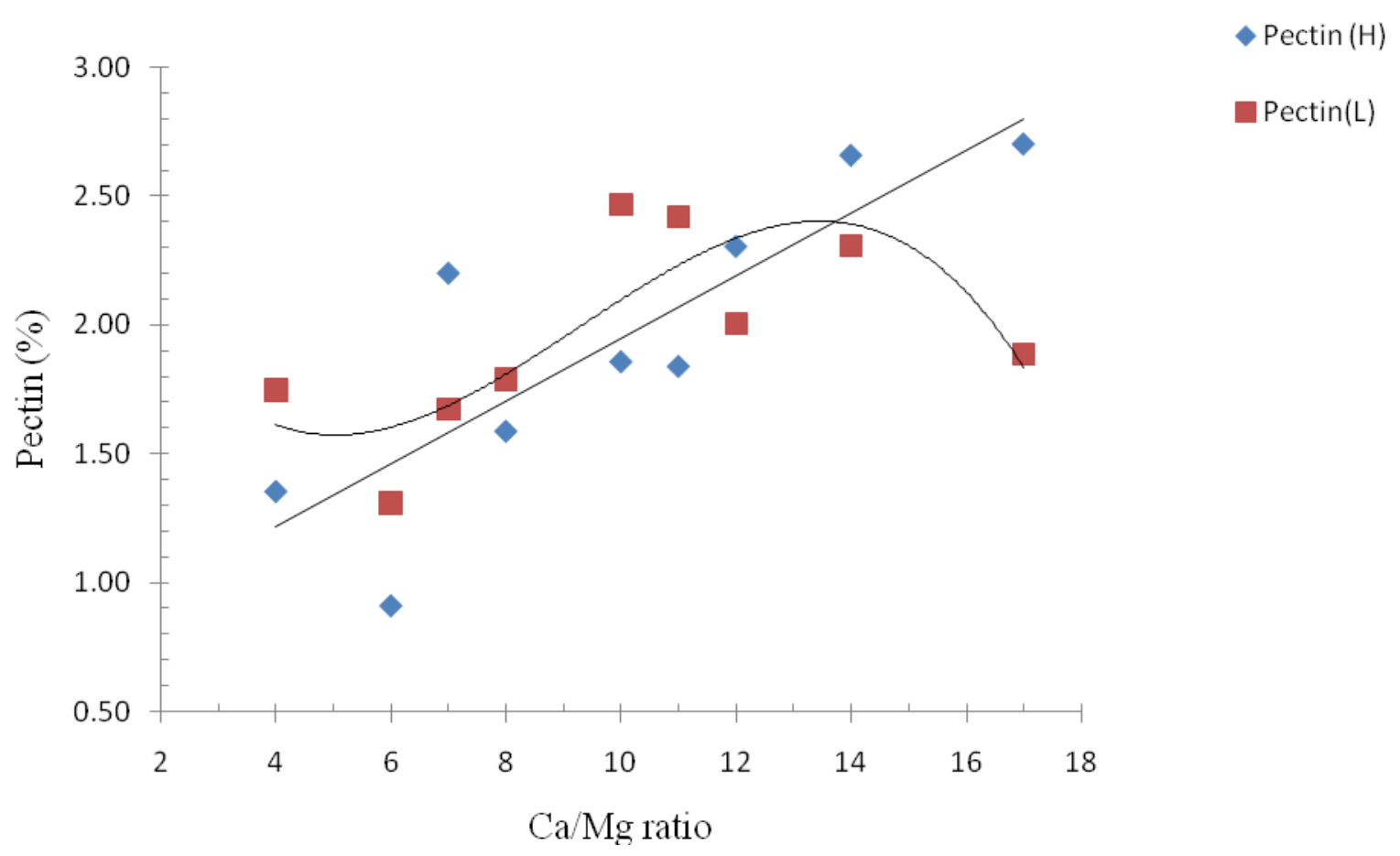

Figure 3.4. Interaction effects of $\mathrm{Ca} / \mathrm{Mg}$ ratio and water potential on pectin concentration in young leaf blade (sudangrass). Pectin (H) represents pectin (\%) in frequently irrigated condition and Pectin (L) represents pectin (\%) in poorly irrigated condition. Solid line represents fitted trend line (polynomial) through all ratios. Fischer's least significant difference (LSD) for each water potential at given $\mathrm{Ca} / \mathrm{Mg}$ ratios are: 0.21 (4:1), 0.28 (6:1), 0.21 (7:1), $0.18(8: 1), 0.28(10: 1), 0.37(11: 1), 0.45(12: 1), 0.37$ (14:1), and 0.49 $(17: 1)$. 


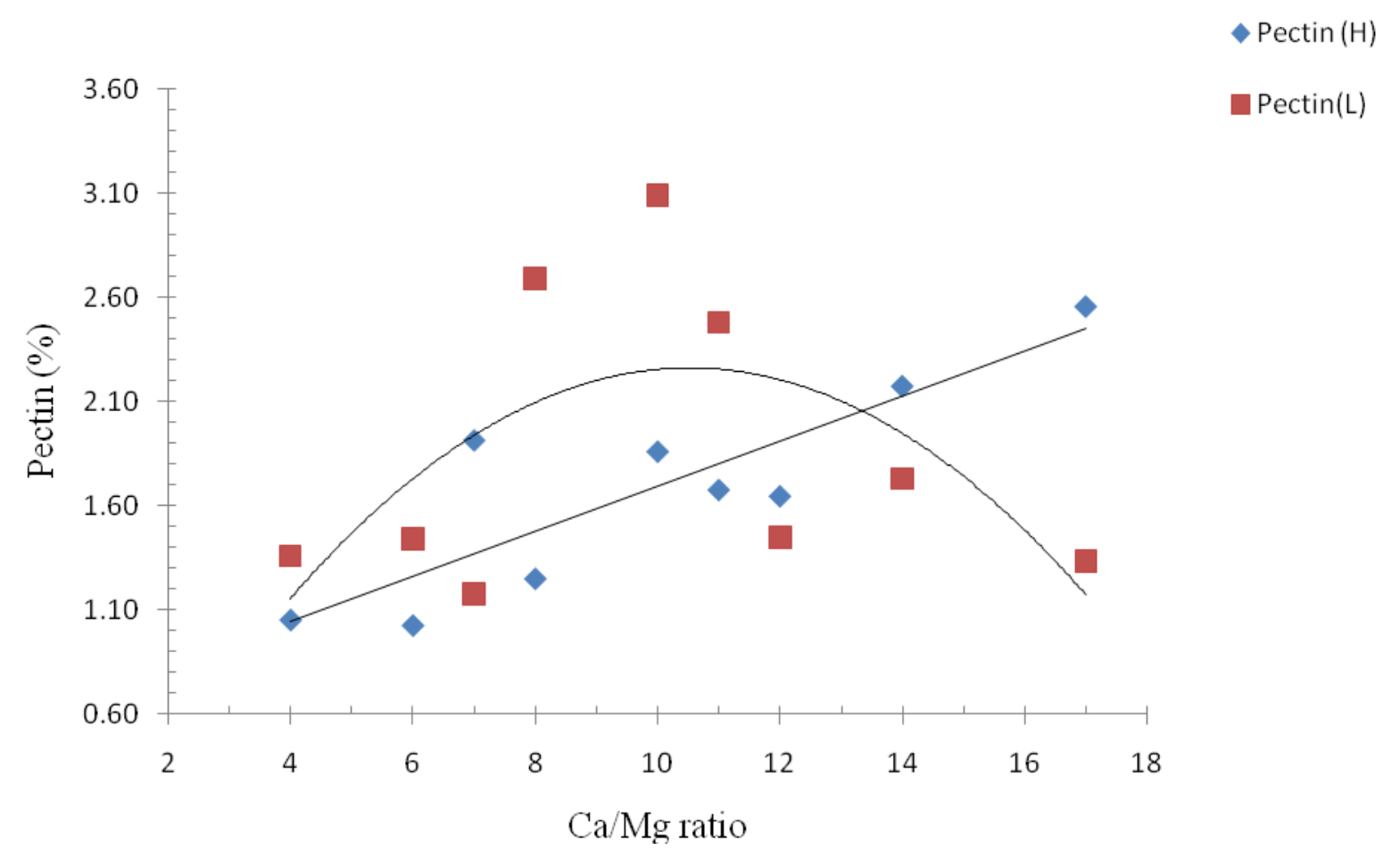

Figure 3.5. Interaction effects of $\mathrm{Ca} / \mathrm{Mg}$ ratio and water potential on pectin concentration in old leaf blade (sudangrass). Pectin $(\mathrm{H})$ represents pectin $(\%)$ in frequently irrigated condition and Pectin (L) represents pectin (\%) in poorly irrigated condition. Solid line represents fitted trend line (polynomial) through all ratios. Fischer's least significant difference (LSD) for each water potential at given $\mathrm{Ca} / \mathrm{Mg}$ ratios are: $0.21(4: 1), 0.64$ (6:1), $0.58(7: 1), 1.64(8: 1), 0.86(10: 1), 0.69(11: 1), 0.13(12: 1), 0.27(14: 1)$, and 0.82 (17:1). 


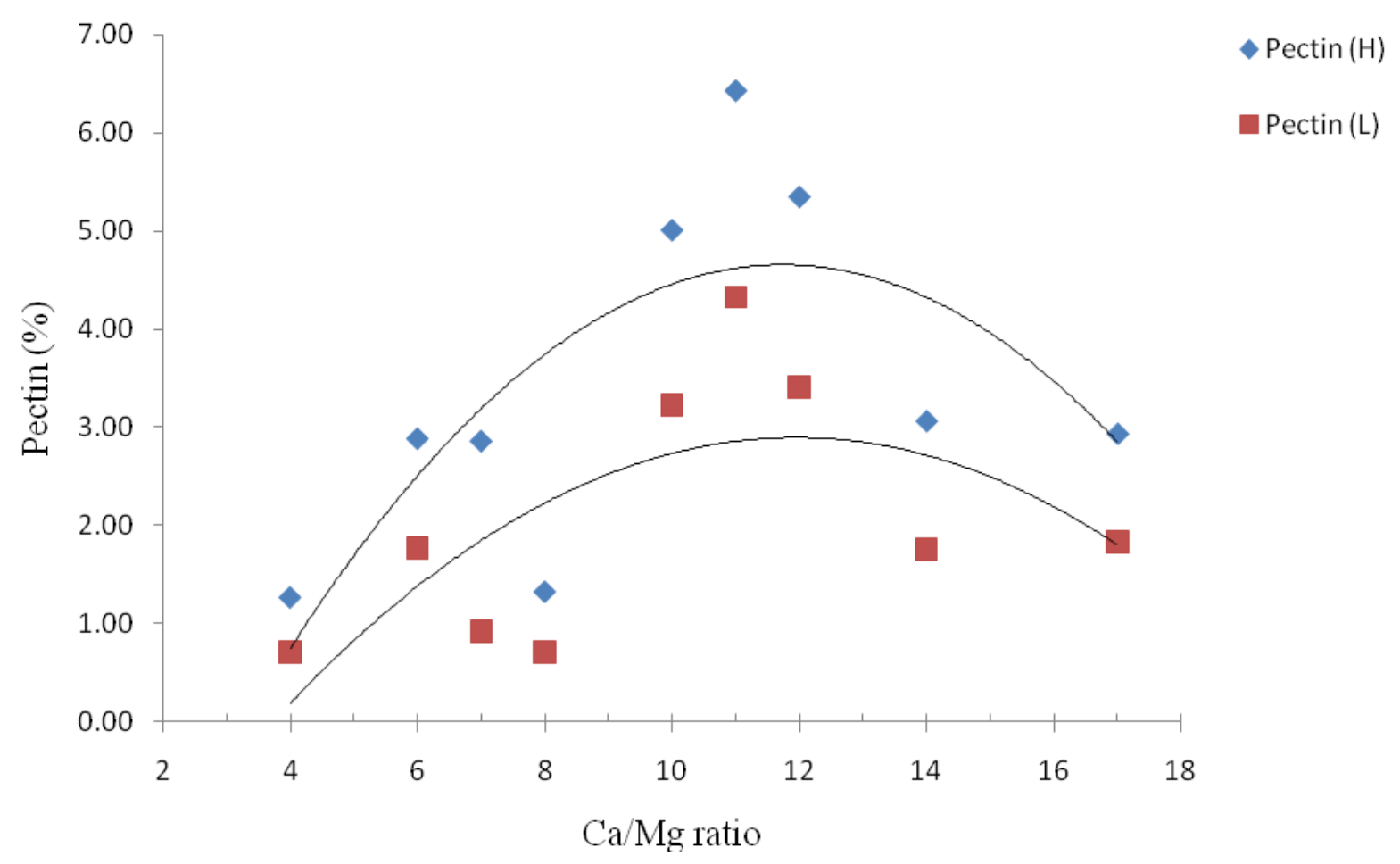

Figure 3.6. Interaction effects of $\mathrm{Ca} / \mathrm{Mg}$ ratio and water potential on pectin concentration in red clover. Solid line represents fitted trend line (polynomial) through all ratios. Pectin $(\mathrm{H})$ represents pectin (\%) in frequently irrigated condition and Pectin (L) represents pectin (\%) in poorly irrigated condition. Fischer's least significant difference (LSD) for each water potential at given $\mathrm{Ca} / \mathrm{Mg}$ ratios are: 0.28 (4:1), 0.34 (6:1), 1.41 (7:1), 0.34 (8:1), $1.00(10: 1), 1.47(11: 1), 0.83(12: 1), 0.70(14: 1)$, and $0.99(17: 1)$. 


\section{Appendix 1}

Table A.1.1. Average daily temperature and water potential averaged over week for the entire growing period. WP $(\mathrm{H})$ represents water potential in frequently irrigated condition and WP (L) represents water potential in poorly irrigated condition.

\begin{tabular}{|c|c|c|c|}
\hline \multirow[b]{2}{*}{ Date } & \multirow[t]{2}{*}{ Temperature $\left({ }^{\circ} \mathrm{C}\right)$} & \multicolumn{2}{|c|}{ Water Potential (pF) } \\
\hline & & $\mathrm{WP}(\mathrm{H})$ & WP (L) \\
\hline July 1-7 & 26.29 & 3.37 & 4.2 \\
\hline July 8-14 & 28.14 & 1.99 & 4.2 \\
\hline July 15- 21 & 30.32 & 2.28 & 4.19 \\
\hline July 22-28 & 27.78 & 1.75 & 4.14 \\
\hline July 29- Aug 4 & 27.98 & 2.4 & 4.19 \\
\hline Aug 5-11 & 28.09 & 2.48 & 4.2 \\
\hline Aug 12-18 & 29.42 & 1.95 & 4.17 \\
\hline Aug 19-25 & 28.29 & 3.23 & 4.19 \\
\hline Aug 26- Sept 1 & 27.02 & 1.39 & 4.09 \\
\hline Sept 2- 7 & 27.08 & 2.33 & 4.21 \\
\hline Sept 8-14 & 22.31 & 3.29 & 4.22 \\
\hline Sept 15- 21 & 28.22 & 3.02 & 4.17 \\
\hline Sept 22- 28 & 28.9 & 1.71 & 4.19 \\
\hline Oct 6- 12 & 28.07 & 2.35 & 4.19 \\
\hline Oct 13-19 & 27.54 & 1.75 & 4.18 \\
\hline Oct $20-25$ & 25.18 & 1.99 & 4.14 \\
\hline Oct 26- Nov 1 & 21.51 & 2.12 & 4.19 \\
\hline Nov 2- 8 & 18.91 & 1.64 & 4.16 \\
\hline Nov 9-15 & 16.61 & 1.23 & 4.17 \\
\hline
\end{tabular}


Table A.1.2. Interaction means for herbage accumulation of sudangrass. WP $(\mathrm{H})$ represents water potential in frequently irrigated condition and WP (L) represents water potential in poorly irrigated condition. SD and SE are standard deviation and standard error of means at each treatment levels.

\begin{tabular}{|c|c|c|c|c|c|c|c|c|}
\hline $\mathrm{Ca}(\mathrm{OH})_{2}-\mathrm{Mg}(\mathrm{OH})_{2}$ & $\mathrm{Ca} / \mathrm{Mg}$ ratio & Reps & \multicolumn{6}{|c|}{$\mathrm{DM}\left(\mathrm{g}_{\mathrm{pot}}{ }^{-1}\right)$} \\
\hline treatment combination & & & WP $(\mathrm{H})$ & SD & SE & $\mathrm{WP}(\mathrm{L})$ & $\mathrm{SD}$ & SE \\
\hline $0-100$ & 4 & 5 & 26.28 & 2.50 & 1.12 & 21.48 & 3.30 & 1.48 \\
\hline $25-75$ & 6 & 5 & 26.08 & 4.27 & 1.91 & 21.97 & 2.38 & 1.06 \\
\hline $50-50$ & 7 & 5 & 24.87 & 0.41 & 0.18 & 13.89 & 2.83 & 1.27 \\
\hline $60-40$ & 8 & 5 & 23.66 & 5.21 & 2.33 & 15.86 & 1.68 & 0.75 \\
\hline $70-30$ & 10 & 5 & 25.54 & 2.18 & 0.98 & 21.96 & 1.90 & 0.85 \\
\hline $75-25$ & 11 & 5 & 25.12 & 0.94 & 0.42 & 18.93 & 3.07 & 1.37 \\
\hline $80-20$ & 12 & 5 & 28.93 & 2.19 & 0.98 & 21.36 & 2.62 & 1.17 \\
\hline $90-10$ & 14 & 5 & 26.13 & 4.55 & 2.04 & 16.88 & 3.04 & 1.36 \\
\hline $100-0$ & 17 & 5 & 20.55 & 4.72 & 2.11 & 13.80 & 3.50 & 1.57 \\
\hline
\end{tabular}


Table A.1.3. Interaction means for crude protein percentage in young leaf blade of sudangrass. WP $(\mathrm{H})$ represents water potential in frequently irrigated condition and WP $(\mathrm{L})$ represents water potential in poorly irrigated condition. SD and SE are standard deviation and standard error of means at each treatment levels.

\begin{tabular}{lcccccccc}
\hline $\mathrm{Ca}(\mathrm{OH})_{2}-\mathrm{Mg}(\mathrm{OH})_{2}$ & $\mathrm{Ca} / \mathrm{Mg}$ Ratio & Reps & \multicolumn{7}{c}{ Crude Protein (\%) } \\
Treatment Combination & & & WP $(\mathrm{H})$ & SD & SE & WP (L) & SD & SE \\
\hline & & & & & & & \\
$0-100$ & 4 & 5 & 8.03 & 0.57 & 0.26 & 9.45 & 0.79 & 0.35 \\
$25-75$ & 6 & 5 & 7.68 & 0.48 & 0.22 & 8.64 & 0.58 & 0.26 \\
$50-50$ & 7 & 5 & 8.01 & 0.35 & 0.16 & 9.83 & 1.02 & 0.46 \\
$60-40$ & 8 & 5 & 7.20 & 0.42 & 0.19 & 8.20 & 0.70 & 0.31 \\
$70-30$ & 10 & 5 & 7.39 & 0.19 & 0.08 & 8.28 & 0.29 & 0.13 \\
$75-25$ & 11 & 5 & 7.09 & 0.43 & 0.19 & 9.64 & 1.63 & 0.73 \\
$80-20$ & 12 & 5 & 7.48 & 0.19 & 0.09 & 9.40 & 1.04 & 0.46 \\
$90-10$ & 14 & 5 & 8.07 & 0.42 & 0.19 & 9.61 & 1.10 & 0.49 \\
$100-0$ & 17 & 5 & 5.79 & 0.11 & 0.05 & 6.90 & 1.19 & 0.53 \\
\hline
\end{tabular}


Table A.1.4. Interaction means for crude protein percentage in old leaf blade of sudangrass. WP $(\mathrm{H})$ represents water potential in frequently irrigated condition and WP (L) represents water potential in poorly irrigated condition. SD and SE are standard deviation and standard error of means at each treatment levels.

\begin{tabular}{lcccccccc}
\hline $\mathrm{Ca}(\mathrm{OH})_{2}-\mathrm{Mg}(\mathrm{OH})_{2}$ & $\mathrm{Ca} / \mathrm{Mg}$ Ratio & Reps & \multicolumn{7}{c}{$\mathrm{CP}(\%)$} \\
Treatment Combination & & & WP $(\mathrm{L})$ & $\mathrm{SD}$ & $\mathrm{SE}$ & $\mathrm{WP}(\mathrm{H})$ & $\mathrm{SD}$ & $\mathrm{SE}$ \\
\hline $0-100$ & 4 & 5 & 6.86 & 0.74 & 0.33 & 10.11 & 1.49 & 0.67 \\
$25-75$ & 6 & 5 & 6.51 & 0.37 & 0.16 & 7.39 & 0.18 & 0.08 \\
$50-50$ & 7 & 5 & 6.05 & 0.34 & 0.15 & 7.28 & 0.34 & 0.15 \\
$60-40$ & 8 & 5 & 6.06 & 0.23 & 0.10 & 7.19 & 0.69 & 0.31 \\
$70-30$ & 10 & 5 & 5.85 & 0.15 & 0.07 & 7.78 & 1.73 & 0.77 \\
$75-25$ & 11 & 5 & 5.45 & 0.52 & 0.23 & 6.23 & 0.58 & 0.26 \\
$80-20$ & 12 & 5 & 5.77 & 0.35 & 0.16 & 6.84 & 0.63 & 0.28 \\
$90-10$ & 14 & 5 & 7.02 & 0.43 & 0.19 & 7.90 & 0.75 & 0.34 \\
$100-0$ & 17 & 5 & 6.05 & 0.38 & 0.17 & 7.46 & 2.27 & 1.02 \\
\hline
\end{tabular}


Table A.1.5. Interaction means for tissue mineral concentration in young leaf blade of sudangrass. WP $(\mathrm{H})$ represents water potential in frequently irrigated condition and WP (L) represents water potential in poorly irrigated condition. SD is standard deviation of means at each treatment levels.

\begin{tabular}{|c|c|c|c|c|c|c|c|c|c|c|}
\hline \multirow[b]{2}{*}{$\mathrm{Ca} / \mathrm{Mg}$ Ratio } & \multirow[b]{2}{*}{ WP } & \multirow[b]{2}{*}{$\mathrm{N}$} & \multicolumn{2}{|c|}{$\mathrm{Ca}(\%)$} & \multicolumn{2}{|c|}{$\operatorname{Mg}(\%)$} & \multicolumn{2}{|c|}{$\mathrm{P}(\%)$} & \multicolumn{2}{|c|}{$\mathrm{K}(\%)$} \\
\hline & & & Mean & Std Dev & Mean & Std Dev & Mean & Std Dev & Mean & Std Dev \\
\hline 4 & $\mathrm{H}$ & 5 & 0.26 & 0.06 & 0.26 & 0.04 & 0.20 & 0.02 & 0.98 & 0.10 \\
\hline 4 & $\mathrm{~L}$ & 5 & 0.19 & 0.01 & 0.20 & 0.01 & 0.17 & 0.03 & 0.98 & 0.06 \\
\hline 6 & $\mathrm{H}$ & 5 & 0.36 & 0.07 & 0.32 & 0.09 & 0.20 & 0.06 & 0.96 & 0.19 \\
\hline 6 & $\mathrm{~L}$ & 5 & 0.24 & 0.04 & 0.25 & 0.03 & 0.18 & 0.04 & 0.95 & 0.13 \\
\hline 7 & $\mathrm{H}$ & 5 & 0.25 & 0.04 & 0.23 & 0.04 & 0.21 & 0.03 & 1.00 & 0.02 \\
\hline 7 & $\mathrm{~L}$ & 5 & 0.20 & 0.02 & 0.20 & 0.02 & 0.20 & 0.03 & 1.02 & 0.08 \\
\hline 8 & $\mathrm{H}$ & 5 & 0.29 & 0.03 & 0.24 & 0.01 & 0.21 & 0.05 & 0.96 & 0.13 \\
\hline 8 & $\mathrm{~L}$ & 5 & 0.24 & 0.04 & 0.22 & 0.04 & 0.18 & 0.03 & 0.95 & 0.11 \\
\hline 10 & $\mathrm{H}$ & 5 & 0.32 & 0.04 & 0.26 & 0.04 & 0.20 & 0.04 & 1.00 & 0.11 \\
\hline 10 & $\mathrm{~L}$ & 5 & 0.21 & 0.03 & 0.21 & 0.03 & 0.21 & 0.02 & 0.96 & 0.07 \\
\hline 11 & $\mathrm{H}$ & 5 & 0.45 & 0.12 & 0.33 & 0.06 & 0.19 & 0.08 & 0.82 & 0.16 \\
\hline 11 & $\mathrm{~L}$ & 5 & 0.26 & 0.05 & 0.22 & 0.03 & 0.21 & 0.05 & 1.07 & 0.11 \\
\hline 12 & $\mathrm{H}$ & 5 & 0.29 & 0.03 & 0.19 & 0.02 & 0.20 & 0.05 & 0.97 & 0.14 \\
\hline 12 & $\mathrm{~L}$ & 5 & 0.23 & 0.02 & 0.18 & 0.02 & 0.19 & 0.04 & 0.96 & 0.08 \\
\hline 14 & $\mathrm{H}$ & 5 & 0.34 & 0.02 & 0.22 & 0.04 & 0.22 & 0.05 & 0.99 & 0.09 \\
\hline 14 & $\mathrm{~L}$ & 5 & 0.23 & 0.03 & 0.16 & 0.01 & 0.18 & 0.04 & 0.94 & 0.13 \\
\hline 17 & $\mathrm{H}$ & 5 & 0.36 & 0.04 & 0.23 & 0.02 & 0.25 & 0.04 & 1.16 & 0.05 \\
\hline 17 & $\mathrm{~L}$ & 5 & 0.28 & 0.03 & 0.17 & 0.02 & 0.25 & 0.02 & 1.16 & 0.08 \\
\hline
\end{tabular}


Table A.1.6. Interaction means for tissue mineral concentration in old leaf blade of sudangrass. WP $(\mathrm{H})$ represents water potential in frequently irrigated condition and WP $(\mathrm{L})$ represents water potential in poorly irrigated condition. SD is standard deviation of mean at each treatment levels.

\begin{tabular}{|c|c|c|c|c|c|c|c|c|c|c|}
\hline \multirow[b]{2}{*}{$\mathrm{Ca} / \mathrm{Mg}$ Ratio } & \multirow[b]{2}{*}{ WP } & \multirow[b]{2}{*}{$\mathrm{N}$} & \multicolumn{2}{|c|}{$\mathrm{Ca}(\%)$} & \multicolumn{2}{|c|}{$\operatorname{Mg}(\%)$} & \multicolumn{2}{|c|}{$\mathrm{P}(\%)$} & \multicolumn{2}{|c|}{$\mathrm{K}(\%)$} \\
\hline & & & Mean & Std Dev & Mean & Std Dev & Mean & Std Dev & Mean & Std Dev \\
\hline 4 & $\mathrm{H}$ & 5 & 0.65 & 0.06 & 0.54 & 0.05 & 0.07 & 0.02 & 0.49 & 0.06 \\
\hline 4 & $\mathrm{~L}$ & 5 & 0.52 & 0.06 & 0.40 & 0.04 & 0.13 & 0.03 & 0.72 & 0.11 \\
\hline 6 & $\mathrm{H}$ & 5 & 0.64 & 0.06 & 0.52 & 0.11 & 0.07 & 0.02 & 0.51 & 0.05 \\
\hline 6 & $\mathrm{~L}$ & 5 & 0.49 & 0.03 & 0.36 & 0.04 & 0.15 & 0.02 & 0.69 & 0.05 \\
\hline 7 & $\mathrm{H}$ & 5 & 0.57 & 0.05 & 0.37 & 0.06 & 0.09 & 0.01 & 0.54 & 0.03 \\
\hline 7 & $\mathrm{~L}$ & 5 & 0.39 & 0.04 & 0.28 & 0.03 & 0.15 & 0.01 & 0.68 & 0.11 \\
\hline 8 & $\mathrm{H}$ & 5 & 0.57 & 0.05 & 0.40 & 0.05 & 0.06 & 0.00 & 0.46 & 0.07 \\
\hline 8 & $\mathrm{~L}$ & 5 & 0.46 & 0.06 & 0.29 & 0.03 & 0.13 & 0.05 & 0.66 & 0.16 \\
\hline 10 & $\mathrm{H}$ & 5 & 0.63 & 0.07 & 0.40 & 0.05 & 0.07 & 0.00 & 0.45 & 0.04 \\
\hline 10 & $\mathrm{~L}$ & 5 & 0.44 & 0.04 & 0.30 & 0.03 & 0.12 & 0.03 & 0.62 & 0.07 \\
\hline 11 & $\mathrm{H}$ & 5 & 0.64 & 0.09 & 0.39 & 0.07 & 0.07 & 0.02 & 0.49 & 0.03 \\
\hline 11 & $\mathrm{~L}$ & 5 & 0.50 & 0.00 & 0.28 & 0.03 & 0.15 & 0.05 & 0.69 & 0.12 \\
\hline 12 & $\mathrm{H}$ & 5 & 0.65 & 0.04 & 0.39 & 0.04 & 0.07 & 0.01 & 0.43 & 0.04 \\
\hline 12 & $\mathrm{~L}$ & 5 & 0.52 & 0.03 & 0.30 & 0.03 & 0.10 & 0.02 & 0.61 & 0.11 \\
\hline 14 & $\mathrm{H}$ & 5 & 0.66 & 0.04 & 0.35 & 0.03 & 0.07 & 0.01 & 0.49 & 0.08 \\
\hline 14 & $\mathrm{~L}$ & 5 & 0.50 & 0.07 & 0.28 & 0.03 & 0.14 & 0.04 & 0.79 & 0.22 \\
\hline 17 & $\mathrm{H}$ & 5 & 0.60 & 0.03 & 0.33 & 0.01 & 0.08 & 0.02 & 0.61 & 0.07 \\
\hline 17 & $\mathrm{~L}$ & 5 & 0.54 & 0.02 & 0.27 & 0.04 & 0.18 & 0.05 & 0.92 & 0.18 \\
\hline
\end{tabular}


Table A.1.7. Interaction means for tissue mineral concentration of red clover. WP $(\mathrm{H})$ represents water potential in frequently irrigated condition and WP (L) represents water potential in poorly irrigated condition. SD is standard deviation of mean at each treatment levels.

\begin{tabular}{|c|c|c|c|c|c|c|c|c|c|c|}
\hline \multirow[b]{2}{*}{$\mathrm{Ca} / \mathrm{Mg}$ Ratio } & \multirow[b]{2}{*}{ WP } & \multirow[b]{2}{*}{$\mathrm{N}$} & \multicolumn{2}{|c|}{$\mathrm{Ca}(\%)$} & \multicolumn{2}{|c|}{$\operatorname{Mg}(\%)$} & \multicolumn{2}{|c|}{$\mathrm{P}(\%)$} & \multicolumn{2}{|c|}{$\mathrm{K}(\%)$} \\
\hline & & & Mean & Std Dev & Mean & Std Dev & Mean & Std Dev & Mean & Std Dev \\
\hline 4 & $\mathrm{H}$ & 5 & 2.46 & 0.12 & 1.02 & 0.04 & 0.16 & 0.01 & 0.64 & 0.06 \\
\hline 4 & $\mathrm{~L}$ & 5 & 2.05 & 0.15 & 0.92 & 0.03 & 0.19 & 0.02 & 0.89 & 0.08 \\
\hline 6 & $\mathrm{H}$ & 5 & 2.40 & 0.05 & 1.06 & 0.02 & 0.19 & 0.02 & 0.60 & 0.04 \\
\hline 6 & $\mathrm{~L}$ & 5 & 2.03 & 0.22 & 0.97 & 0.07 & 0.23 & 0.02 & 0.91 & 0.16 \\
\hline 7 & $\mathrm{H}$ & 5 & 2.59 & 0.29 & 1.07 & 0.05 & 0.17 & 0.01 & 0.67 & 0.08 \\
\hline 7 & $\mathrm{~L}$ & 5 & 2.04 & 0.19 & 0.93 & 0.05 & 0.20 & 0.02 & 0.89 & 0.09 \\
\hline 8 & $\mathrm{H}$ & 5 & 2.16 & 0.11 & 0.97 & 0.03 & 0.19 & 0.01 & 0.65 & 0.13 \\
\hline 8 & $\mathrm{~L}$ & 5 & 1.97 & 0.12 & 0.85 & 0.05 & 0.24 & 0.01 & 1.04 & 0.13 \\
\hline 10 & $\mathrm{H}$ & 5 & 2.49 & 0.16 & 0.96 & 0.07 & 0.17 & 0.01 & 0.62 & 0.05 \\
\hline 10 & $\mathrm{~L}$ & 5 & 2.18 & 0.11 & 0.82 & 0.04 & 0.20 & 0.02 & 0.74 & 0.05 \\
\hline 11 & $\mathrm{H}$ & 5 & 2.90 & 0.09 & 0.94 & 0.05 & 0.19 & 0.01 & 0.74 & 0.02 \\
\hline 11 & $\mathrm{~L}$ & 5 & 2.53 & 0.19 & 0.85 & 0.03 & 0.22 & 0.02 & 0.91 & 0.14 \\
\hline 12 & $\mathrm{H}$ & 5 & 2.66 & 0.18 & 0.98 & 0.05 & 0.20 & 0.01 & 0.72 & 0.07 \\
\hline 12 & $\mathrm{~L}$ & 5 & 2.15 & 0.07 & 0.78 & 0.08 & 0.23 & 0.02 & 0.98 & 0.16 \\
\hline 14 & $\mathrm{H}$ & 5 & 2.94 & 0.20 & 0.92 & 0.01 & 0.17 & 0.01 & 0.67 & 0.06 \\
\hline 14 & $\mathrm{~L}$ & 5 & 2.50 & 0.18 & 0.79 & 0.04 & 0.20 & 0.01 & 0.86 & 0.06 \\
\hline 17 & $\mathrm{H}$ & 5 & 2.64 & 0.13 & 0.96 & 0.03 & 0.16 & 0.02 & 0.65 & 0.05 \\
\hline 17 & $\mathrm{~L}$ & 5 & 2.27 & 0.10 & 0.89 & 0.04 & 0.20 & 0.01 & 0.82 & 0.10 \\
\hline
\end{tabular}




\section{Appendix 2. Titration Experiment}

Incremental addition of $0.022 \mathrm{M} \mathrm{Ca}(\mathrm{OH})_{2}$ resulted in gradual increase in $\mathrm{pH}$ until it

reached equilibrium at the end of $5^{\text {th }}$ day. Thereafter $\mathrm{pH}$ remained stable and attained a constant value of 6.67 when measured for another two consecutive days. The result closely matches with the direct titration experiment of Dunn (1943) to predict the lime requirement of acid soils with the exception that his experiment took only 4 days to reach equilibrium without shaking.

Base addition and $\mathrm{pH}$ increment was also found to be nearly linearly within $\mathrm{pH}$ range of 5.8-6.67 (Figure A.2.1). This observation is also consistent with those of Magdoff and Bartlett (1985) and Weaver et al. (2004) where they found that $\mathrm{pH}$ of most agricultural soils followed a linear relationship with base addition between $\mathrm{pH}$ range of 4.5-6.5. With additional amounts of base added $\left(\mathrm{Ca}(\mathrm{OH})_{2}\right), \mathrm{Al}^{3+}$ is displaced from the exchangeable complex and replaced with the basic cation ( $\mathrm{Ca}$ or $\mathrm{Mg}$ depending on base used).

Following titration, regression equation was obtained by fitting the relationship between the base added (abscissa) and $\mathrm{pH}$ (ordinate) (Figure A.2.1). The equation of the line of best fit was estimated and given by Eq. (1).The standard error of the slope was 0.007 and the corresponding $\mathrm{p}$ value was $<0.0001$. The $\mathrm{R}^{2}$ value was 0.962 . The residual or unexplained variation was 0.02 .

$$
\mathrm{pH}=5.923+0.6505 \mathrm{LR}\left[\mathrm{Ca}(\mathrm{OH})_{2}\right](\mathrm{Mg} / \mathrm{ha})
$$

Lime requirement was calculated based on the slope of the linear regression equation and the $\mathrm{pH}$ difference between initial $\mathrm{pH}$ and the target $\mathrm{pH}(\sim 6.5)($ Eq. 2$)$. 
LR $\left(\mathrm{CaCO}_{3} \mathrm{Mg} / \mathrm{ha}\right)=6.5-\frac{\text { Int } \mathrm{pH}}{\mathrm{b}}$

where, LR is the lime requirement, Int. $\mathrm{pH}$ is the $\mathrm{y}$ intercept and $\mathrm{b}$ is the slope of the linear equation. Buffering capacity of the soil was calculated as $1 / \mathrm{b}$ with units of $\operatorname{cmol}(+) \mathrm{kg}^{-1} \mathrm{pH}^{-1}(\mathrm{Liu}$ et al. 2004). The buffering capacity of the soil was found to be $6.99 \mathrm{cmol}(+) \mathrm{kg}^{-1} \mathrm{pH}^{-1}$. It can also be inferred that because of the higher buffering capacity of soil, it took longer time to attain a stable $\mathrm{pH}$ (5 days).

The amount of $\mathrm{Ca}(\mathrm{OH})_{2}$ required to adjust the $\mathrm{pH}$ to 6.5 was found to be $683 \mathrm{mg} \mathrm{kg}^{-1}$ soil ( $\sim 0.89 \mathrm{Mg} \mathrm{CaCO}_{3} \mathrm{ha}^{-1}$ ) This value corresponded to a molar equivalence of 0.0092 moles of $\mathrm{Ca}(\mathrm{OH})_{2}$. The calculation of liming ratio were based on this value. The amount of $\mathrm{Ca}(\mathrm{OH})_{2}$ and $\mathrm{Mg}(\mathrm{OH})_{2}$ for the corresponding treatment combinations are presented in (Table A.2.3).

Addition of the molar combination of $\mathrm{Ca}(\mathrm{OH})_{2}$ and $\mathrm{Mg}(\mathrm{OH})_{2}$ followed by mixing procedure resulted in increase in soil $\mathrm{pH}$ across all the nine treatment combinations. The average $\mathrm{pH}$ was $6.43 \pm 0.02$. The means are presented in Table A.2.4. The $\mathrm{pH}$ was approximately close as predicted by the regression equation. The percentage departure from the target $\mathrm{pH}$ was $1 \%$. This result is consistent with the result of Islam et al (2001) where they tried to adjust the pH of soil to 5.2. However after the mixing procedure, they could only achieve a $\mathrm{pH}$ of 5.16. They attributed this departure to less intimate contact of the soil with calcium carbonate. Under lab conditions it is easy to carry uniform mixing of liming agents since mixing occurs in 1:1 soil water suspension which is hard to mimic when using larger volume of soil (Dunn 1943).

Addition of each combination of $\mathrm{Ca}(\mathrm{OH})_{2}$ and $\mathrm{Mg}(\mathrm{OH})_{2}$ resulted in a proportional increase in soil $\mathrm{Ca}$ and $\mathrm{Mg}$. The resulting soil $\mathrm{Ca} / \mathrm{Mg}$ ratio obtained from the Mehlich1 test ranged from 4:1 to 17:1. This ratio was used for all comparison purpose (Table 3.2). 


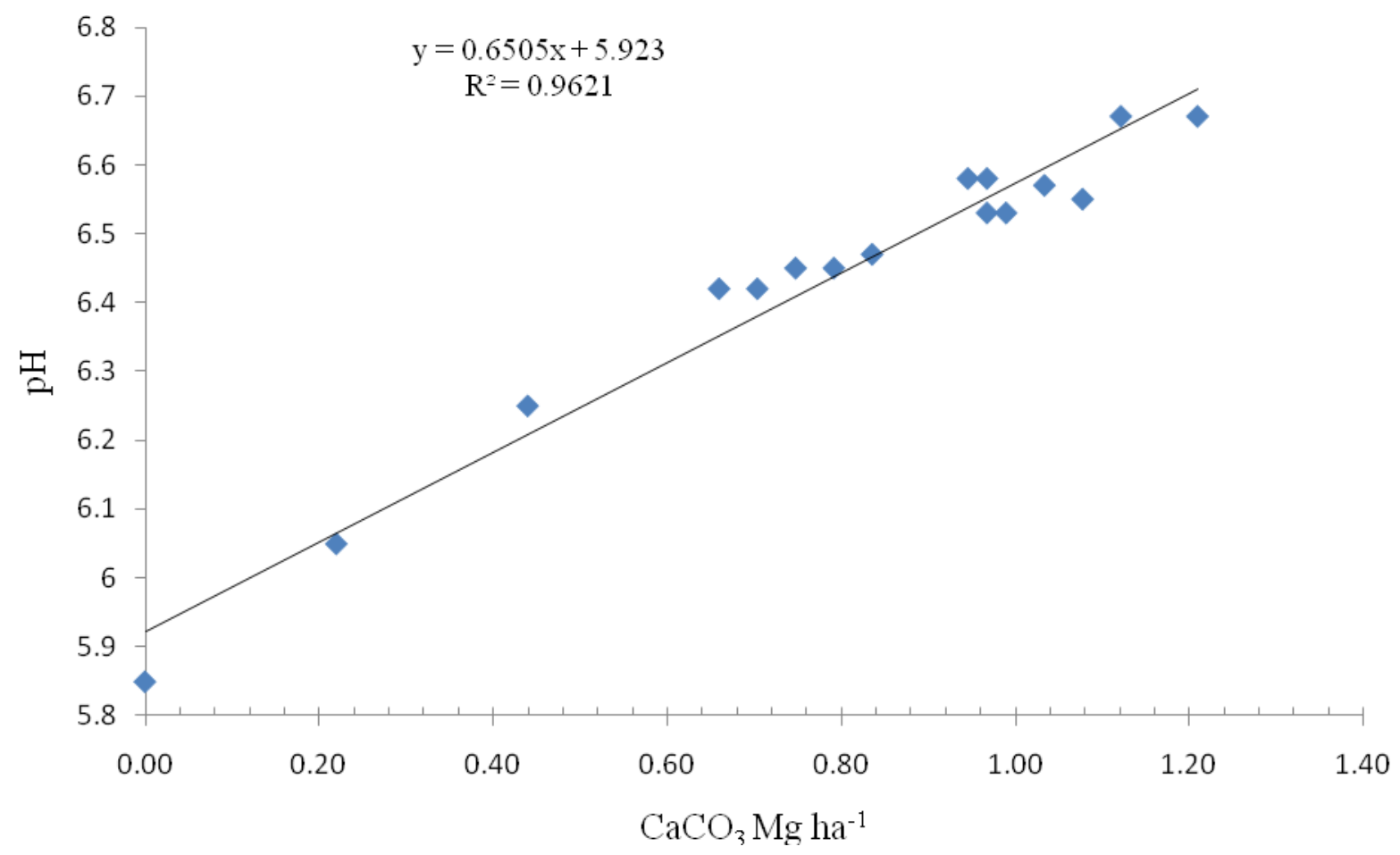

Figure A.2.1. Soil titration with $0.022 \mathrm{M} \mathrm{Ca}(\mathrm{OH})_{2}$ used for prediction of lime requirement. 
Table A.2.1. ANOVA table for titration experiment.

\begin{tabular}{|c|c|c|c|c|c|}
\hline \multicolumn{6}{|c|}{ Analysis of Variance } \\
\hline Source & DF & Sum of & Mean & F Value & $\operatorname{Pr}>F$ \\
\hline & & Squares & Square & & \\
\hline Model & 1 & 0.70 & 0.70 & 355.86 & $<0.0001$ \\
\hline Error & 14 & 0.03 & 0.002 & & \\
\hline Corrected Total & 15 & 0.73 & & & \\
\hline
\end{tabular}


Table A.2.2. Summary statistics for titration experiment.

\begin{tabular}{|c|c|c|c|c|c|c|}
\hline $\begin{array}{l}\text { Vol. of } 0.022 \mathrm{M} \\
\mathrm{Ca}(\mathrm{OH})_{2} \\
(\mathrm{ml}) \\
\end{array}$ & $\mathrm{pH}$ & $\begin{array}{l}\text { Predicted } \\
\text { pH }\end{array}$ & \multicolumn{2}{|c|}{ 95\% CL Mean } & Residual & $\begin{array}{l}\text { Std Error } \\
\text { (Predicted) }\end{array}$ \\
\hline 0 & 5.85 & 5.92 & 5.86 & 5.99 & -0.07 & 0.03 \\
\hline 1 & 6.05 & 6.07 & 6.02 & 6.11 & -0.02 & 0.02 \\
\hline 2 & 6.25 & 6.21 & 6.17 & 6.24 & 0.04 & 0.02 \\
\hline 3 & 6.42 & 6.35 & 6.33 & 6.38 & 0.07 & 0.01 \\
\hline 3.2 & 6.42 & 6.38 & 6.36 & 6.41 & 0.04 & 0.01 \\
\hline 3.4 & 6.45 & 6.41 & 6.39 & 6.43 & 0.04 & 0.01 \\
\hline 3.6 & 6.45 & 6.44 & 6.41 & 6.46 & 0.01 & 0.01 \\
\hline 3.8 & 6.47 & 6.47 & 6.44 & 6.49 & 0.00 & 0.01 \\
\hline 4.3 & 6.58 & 6.54 & 6.51 & 6.56 & 0.04 & 0.01 \\
\hline 4.4 & 6.58 & 6.55 & 6.53 & 6.58 & 0.03 & 0.01 \\
\hline 4.4 & 6.53 & 6.55 & 6.53 & 6.58 & -0.02 & 0.01 \\
\hline 4.5 & 6.53 & 6.57 & 6.54 & 6.59 & -0.04 & 0.01 \\
\hline 4.7 & 6.57 & 6.60 & 6.57 & 6.63 & -0.03 & 0.01 \\
\hline 4.9 & 6.55 & 6.62 & 6.59 & 6.66 & -0.07 & 0.01 \\
\hline 5.1 & 6.67 & 6.65 & 6.62 & 6.69 & 0.02 & 0.02 \\
\hline 5.5 & 6.67 & 6.71 & 6.67 & 6.75 & -0.04 & 0.02 \\
\hline
\end{tabular}


Table A.2.3. Amount of liming agents applied to each treatment combinations.

\begin{tabular}{lcccc}
\hline $\mathrm{Ca}(\mathrm{OH})_{2}-\mathrm{Mg}(\mathrm{OH})_{2}$ & $\mathrm{Ca}$ & $\mathrm{Mg}$ & $\mathrm{Ca}(\mathrm{OH})_{2}$ Applied & $\mathrm{Mg}(\mathrm{OH})_{2}$ Applied \\
\cline { 2 - 5 } Treatment Combination $(\%)$ & $\%$ & $\%$ & $\mathrm{mg} / \mathrm{kg}$ soil & $\mathrm{mg} / \mathrm{kg}$ soil \\
\hline $0-100$ & 0 & 100 & 0 & 536 \\
$25-75$ & 25 & 75 & 170 & 402 \\
$50-50$ & 50 & 50 & 340 & 268 \\
$60-40$ & 60 & 40 & 409 & 215 \\
$70-30$ & 70 & 30 & 477 & 161 \\
$75-25$ & 75 & 25 & 511 & 134 \\
$80-20$ & 80 & 20 & 545 & 107 \\
$90-10$ & 90 & 10 & 613 & 54 \\
$100-0$ & 100 & 0 & 681 & 0 \\
\hline
\end{tabular}


Table A.2.4. Soil $\mathrm{pH}$ after mixing with respective treatment combination. Values equal \pm one standard deviation.

$\mathrm{Ca}(\mathrm{OH})_{2}-\mathrm{Mg}(\mathrm{OH})_{2} \quad \mathrm{pH}$

Treatment Combination (\%)

0-100

$25-75$

$50-50$

$60-40$

70-30

$75-25$

$80-20$

$90-10$

$100-0$
$6.43 \pm 0.04$

$6.41 \pm 0$

$6.41 \pm 0.05$

$6.44 \pm 0.01$

$6.43 \pm 0.04$

$6.45 \pm 0$

$6.44 \pm 0.01$

$6.45 \pm 0.04$

$6.48 \pm 0.01$ 


\section{Appendix 3}

Table A.3.1. Interaction means for pectin concentration in sudangrass and red clover. WP $(\mathrm{H})$ represents water potential in frequently irrigated condition and WP (L) represents water potential in poorly irrigated condition. SE is standard error of means at each treatment levels.

\begin{tabular}{|c|c|c|c|c|c|c|c|c|c|c|c|c|c|c|}
\hline & & & \multicolumn{8}{|c|}{ Sudangrass } & \multicolumn{4}{|c|}{ Red clover } \\
\hline & & & \multicolumn{4}{|c|}{ Young leaf blade } & \multicolumn{4}{|c|}{ Old leaf blade } & & & & \\
\hline \multicolumn{3}{|c|}{$\mathrm{Ca}(\mathrm{OH})_{2}-\mathrm{Mg}(\mathrm{OH})_{2}$} & & & & & 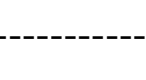 & & $-(\%)---$ & & & & & \\
\hline $\begin{array}{l}\text { Treatment } \\
\text { Combination }\end{array}$ & $\begin{array}{c}\mathrm{Ca} / \mathrm{Mg} \\
\text { ratio }\end{array}$ & $\mathrm{N}$ & WP $(\mathrm{H})$ & SE & WP (L) & SE & WP $(\mathrm{H})$ & SE & WP (L) & SE & WP $(\mathrm{H})$ & SE & WP (L) & SE \\
\hline $0-100$ & 4 & 5 & 1.35 & 0.07 & 1.75 & 0.05 & 1.05 & 0.04 & 1.36 & 0.08 & 1.26 & 0.10 & 0.71 & 0.07 \\
\hline $25-75$ & 6 & 5 & 0.91 & 0.04 & 1.31 & 0.12 & 1.02 & 0.05 & 1.44 & 0.28 & 2.88 & 0.12 & 1.77 & 0.09 \\
\hline $50-50$ & 7 & 5 & 2.20 & 0.07 & 1.67 & 0.06 & 1.91 & 0.24 & 1.18 & 0.07 & 2.86 & 0.60 & 0.92 & 0.12 \\
\hline $60-40$ & 8 & 5 & 1.59 & 0.06 & 1.79 & 0.05 & 1.25 & 0.06 & 2.69 & 0.71 & 1.32 & 0.14 & 0.71 & 0.06 \\
\hline $70-30$ & 10 & 5 & 1.86 & 0.09 & 2.47 & 0.08 & 1.86 & 0.07 & 3.09 & 0.36 & 5.01 & 0.39 & 3.22 & 0.19 \\
\hline $75-25$ & 11 & 5 & 1.84 & 0.13 & 2.42 & 0.10 & 1.67 & 0.07 & 2.48 & 0.29 & 6.43 & 0.59 & 4.32 & 0.24 \\
\hline $80-20$ & 12 & 5 & 2.31 & 0.19 & 2.00 & 0.04 & 1.64 & 0.04 & 1.44 & 0.04 & 5.35 & 0.31 & 3.41 & 0.18 \\
\hline $90-10$ & 14 & 5 & 2.66 & 0.13 & 2.31 & 0.09 & 2.17 & 0.10 & 1.73 & 0.07 & 3.06 & 0.23 & 1.75 & 0.20 \\
\hline $100-0$ & 17 & 5 & 2.70 & 0.19 & 1.89 & 0.08 & 2.55 & 0.36 & 1.33 & 0.00 & 2.93 & 0.41 & 1.83 & 0.14 \\
\hline
\end{tabular}




\section{Appendix 4. Pectin determination}

The following procedure is a modification of the method outlined by Stern and Endres (1991). Two hundred mg of freeze dried, ground homogenate was weighed in a polypropylene centrifuge tube (Becton and Dickinson Co. USA) and $2.5 \mathrm{ml}$ of $72 \%$ sulphuric acid was added to it. The tube was mixed by vortex generator (Vortex-2 Genie, Scientific industries Inc., NY, USA).Samples were then placed in $30^{\circ} \mathrm{C}$ water bath (Model 188, Precision Scientific Inc., Chicago, USA) for $1 \mathrm{hr}$ and stirred every 20 minutes. Final volume was made to $45 \mathrm{ml}$ and vortexed before centrifuging at $1600 \times \mathrm{g}$ for 15 minutes. The supernatant was filtered through Whatman no 42 and $100 \mu \mathrm{l}$ of aliquot was taken in $15 \mathrm{ml}$ borosilicate glass tube and chilled on ice. Exactly $2.4 \mathrm{ml}$ of $0.125 \mathrm{M}$ sodium tetraborate (Fisher Scientific, NJ, USA) in $18 \mathrm{M}$ sulphuric acid (ACS plus, Fisher Scientific, NJ, USA) was then added slowly down the side of the tube and vortexed two times. To reduce the interferences caused by neutral sugars, $40 \mu \mathrm{l}$ of $4 \mathrm{M}$ sulphamic acid (Fisher scientific, NJ, USA) ( $\mathrm{pH}$ 1.6) was also added and the mixture vortexed (FilisettiCozzi and Carpita 1991). The mixture was then heated in $100^{\circ} \mathrm{C}$ water bath for 15 minutes followed by cooling on ice bath for 10 minutes. Glass marbles were placed on the top of the tubes to prevent the contamination of samples. Finally $80 \mu 1$ of $0.15 \%$ (wt/wt) 3-phenylphenol (Tokyo Chemical Industry Co., Tokyo, Japan) in $0.5 \%$ (wt/vol) NaOH (Acros Organics, NJ, USA) was added to the sample and vortexed two times. Blank received $80 \mu 1$ of $0.5 \%$ (wt/vol) $\mathrm{NaOH}$. A pink color developed and remained stable for 45 minutes. The absorbance was recorded at $525 \mathrm{~nm}$ with a Cary 50 UV Spectrophotometer (Varian, Inc., Palo Alto, CA, USA). Several concentrations of D-galacturonic acid (Pfaltz and Bauer Inc. CT, USA) were used to generate the standard curve. 


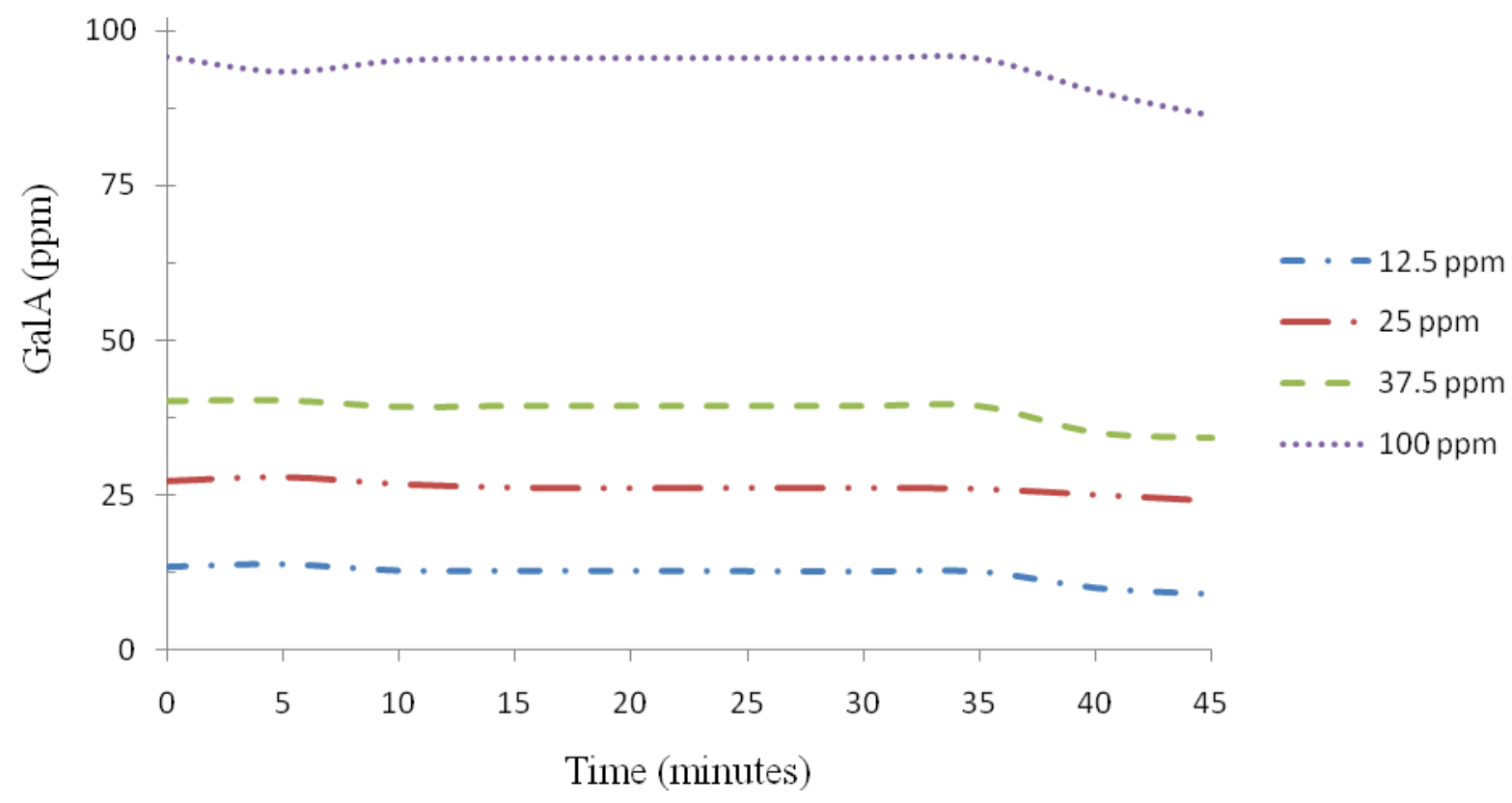

Figure A.4.1. Stability of Galacturonic acid (GalA) standards with time. 


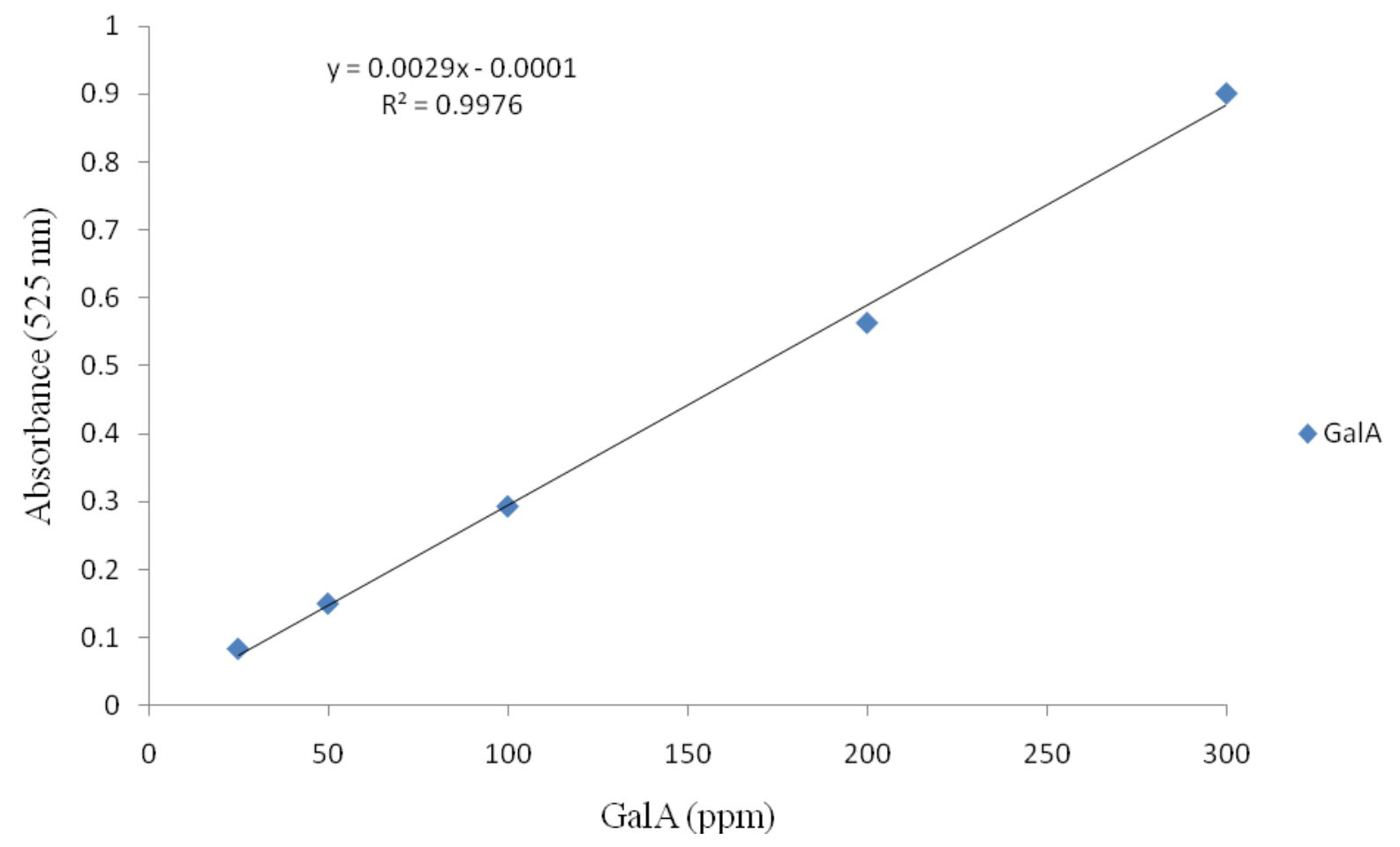

Figure A.4.2. Standard curve for Galacturonic Acid (GalA).

Table A.4.1 Detection limits for Galacturonic acid.

\begin{tabular}{cc}
\hline Detection Limit Definition & ppm \\
\hline Lowest Limit of Detection & 1.75 \\
Method Limit of Detection & 1.83 \\
Limit of Quantification & 5.82 \\
Practical Quantification Limit & 9.14 \\
\hline
\end{tabular}




\section{Appendix 5. Fiber Determinations.}

\section{A.5.1. Neutral detergent fiber (NDF)}

Air dried samples $(0.5 \mathrm{~g})$ were individually weighed into filter bags and digested for 75 minutes as a group of 24 in $2 \mathrm{~L}$ of neutral detergent solution. One blank bag was included in each run to determine blank bag correction. This accounts for any moisture or weight loss in the bags. Four $\mathrm{ml}$ of heat stable alpha amylase and $20 \mathrm{~g}$ sodium sulfite were added at the start of digestion. After 75 minute of digestion, samples were rinsed three times with boiling water $\left(85-90^{\circ} \mathrm{C}\right)$ for 5 minutes. $4 \mathrm{ml}$ of alpha-amylase was added to first and second rinse. Final rinse was done with cold water followed by an acetone rinse and drying at $105^{\circ} \mathrm{C}$ for 2 hours. NDF was calculated as loss of weight on digestion of fiber.

\section{A.5.2. Acid detergent fiber (ADF)}

Acid detergent fiber determination was done on the NDF residue filter bags. Filter bags were digested for 60 minutes as a group of 24 in 2L of ADF solution (AOAC 973.18 C) in ANKOM A200 digestion unit. One blank bag was included in each run to determine blank bag correction. After 60 minutes of digestion, samples were rinsed three times with boiling water $\left(85-90^{\circ} \mathrm{C}\right)$ and one time with cold water for 5 minutes in filter bags followed by an acetone rinse and drying at $105^{\circ} \mathrm{C}$ for 2 hours.ADF was calculated as loss of weight on digestion of fiber residue.

\section{A.5.3. Acid detergent lignin (ADL)}

Acid detergent lignin determination was done on the ADF residue filter bag. ADF residue filter bags were digested as a group of 24 in $72 \%$ w/w sulfuric acid for 3 hours. The bags were 
agitated at 30 minutes interval. At the end of three hours, $\mathrm{H}_{2} \mathrm{SO}_{4}$ was poured off and filter bags were rinsed with warm water repeatedly until neutral $\mathrm{pH}$ followed by an acetone rinse and drying at $105^{\circ} \mathrm{C}$ for 4 hours. ADL was calculated as loss of weight on digestion of fiber residue.

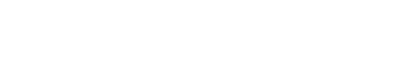

